Prepared in cooperation with the BUREAU OF LAND MANAGEMENT

\title{
Ephemeral-Stream Channel and Basin-Floor Infiltration and Recharge in the Sierra Vista Subwatershed of the Upper San Pedro Basin, Southeastern Arizona
}

Open-File Report 2005-1023

U.S. Department of the Interior

U.S. Geological Survey 
These pages left blank intentionally. 


\section{Ephemeral-Stream Channel and Basin-Floor Infiltration and Recharge in the Sierra Vista Subwatershed of the Upper San Pedro Basin, Southeastern Arizona}

By A.L. Coes and D.R. Pool

Prepared in cooperation with the

BUREAU OF LAND MANAGEMENT and the UPPER SAN PEDRO PARTNERSHIP

Open-File Report 2005-1023 


\section{U.S. Department of the Interior \\ Gale A. Norton, Secretary \\ U.S. Geological Survey \\ P. Patrick Leahy, Acting Director}

U.S. Geological Survey, Reston, Virginia: 2005

For sale by U.S. Geological Survey, Information Services
Box 25286, Denver Federal Center
Denver, CO 80225
Prepared by the Arizona Water Science Center, Tucson.
For more information about the USGS and its products:
Telephone: 1-888-ASK-USGS
World Wide Web: http://www/usgs.gov/

Any use of trade, product, or firm names in this publication is for descriptive purposes only and does not imply endorsement by the U.S. Government.

Although this report is in the public domain, permission must be secured from the individual copyright owners to reproduce any copyrighted materials contained within this report.

Suggested citation:

Coes, A.L., and Pool, D.R., 2005, Ephemeral-stream channel and basin-floor infiltration and recharge in the Sierra Vista subwatershed of the Upper San Pedro Basin, southeastern Arizona: U.S. Geological Survey Open-File Report 2005-1023, 67 p. 


\section{Cooperative Arrangements}

The studies documented in this report were the result of cooperative arrangements beginning in 2000 that were made to address water-resource concerns in the Sierra Vista Subwatershed identified by the Upper San Pedro Partnership, a consortium of 21 Federal, State, and local agencies and organizations. The U.S. Geological Survey, in cooperation with the Bureau of Land Management, conducted a study of ephemeral channel recharge at the request of the Partmership. 
This page left blank intentionally. 


\section{Contents}

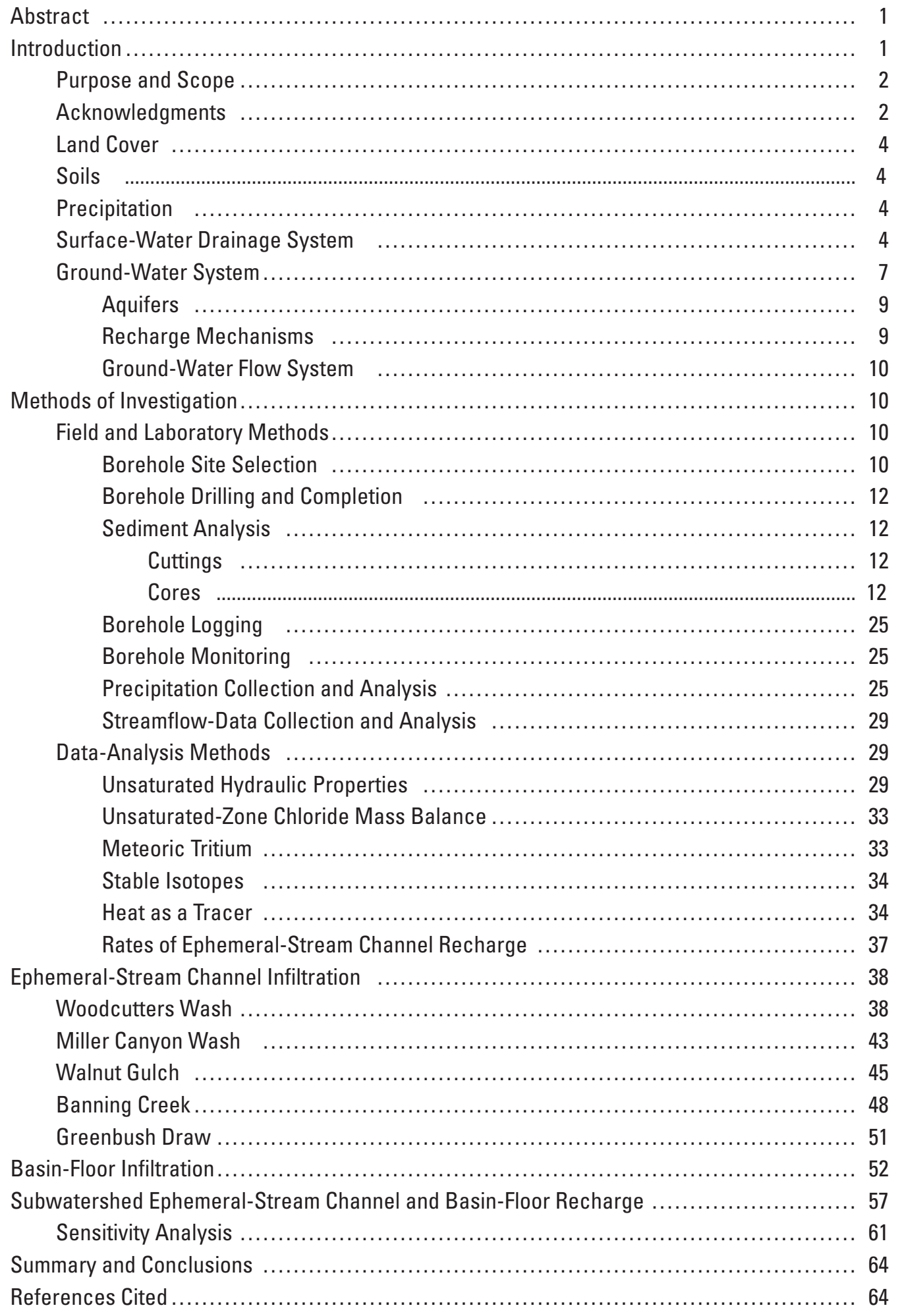




\section{Figures}

1. Map showing Sierra Vista subwatershed, locations of boreholes, temperature sensors, Agricultural Research Service flumes, U.S. Geological Survey streamflow-gaging stations, and precipitation gages, southeastern Arizona and northeastern Sonora, Mexico

2. Map showing land cover and locations of borehole sites, Sierra Vista subwatershed, Arizona

3. Map showing soil type and locations of borehole sites, Sierra Vista subwatershed, Arizona

4. Graphs showing monthly and annual precipitation, Tombstone and Huachuca Mountains gages, Sierra Vista subwatershed, Arizona...

5. Map showing tributary drainage basins and locations of borehole sites, Sierra Vista subwatershed, Arizona and northeastern Sonora, Mexico

6. Graphs showing neutron soil-moisture, electrical conductivity, field grain-size, and laboratory grain-size data for boreholes, Sierra Vista subwatershed, Arizona. $\boldsymbol{A}, \mathrm{WC4a} ; \boldsymbol{B}, \mathrm{WC3} ; \boldsymbol{C}, \mathrm{WC2} \boldsymbol{D}, \mathrm{WC1} ; \boldsymbol{E}, \mathrm{MC2}$; $\boldsymbol{F}, \mathrm{MC1} ; \boldsymbol{G}, \mathrm{WG} 3 ; \boldsymbol{H}, \mathrm{WG} 2 ; \boldsymbol{I}, \mathrm{WG} 1 ; \boldsymbol{J}, \mathrm{BC} 1 ; \boldsymbol{K}, \mathrm{GD} 2 ; \boldsymbol{L}, \mathrm{GD} 1 ; \boldsymbol{M}, \mathrm{WG} 4$ $\boldsymbol{N}$, WG5; O, BF1; $\boldsymbol{P}, \mathrm{WC4C}$

7. Graph showing regression of streamflow duration to distance from the mountain front, 2001 and 2002, Sierra Vista subwatershed, Arizona

8. Graphs showing water levels and streamflow durations from temperature sensors, Woodcutters Wash boreholes, Sierra Vista subwatershed, Arizona. A, WC4a; $\boldsymbol{B}$, WC1

9. Graphs showing sediment-chloride and pore-water tritium data, Woodcutters Wash boreholes, Sierra Vista subwatershed, Arizona.

$\boldsymbol{A}$, WC4a; $\boldsymbol{B}$, WC3; $\boldsymbol{C}$, WC2; $\boldsymbol{D}$, WC1

10. Graphs showing stable-isotope data for pore water collected from Woodcutters Wash boreholes and for precipitation, Sierra Vista subwatershed, Arizona

11. Graph showing streamflow duration and sediment temperatures from sensors and from VS2DH model output, Woodcutters Wash borehole WC1, Sierra Vista subwatershed, July 7, 2001

12. Graphs showing sediment-chloride and pore-water tritium data, Miller Canyon Wash boreholes, Sierra Vista subwatershed, Arizona.

A, MC2; $B$, MC1

13. Graphs showing stable-isotope data for pore water collected from Miller Canyon Wash boreholes and for precipitation, Sierra Vista subwatershed, Arizona

14. Graphs showing sediment-chloride and pore-water tritium data, Walnut Gulch boreholes, Sierra Vista subwatershed, Arizona.

$\boldsymbol{A}, \mathrm{WG} 3 ; \boldsymbol{B}, \mathrm{WG} 2 ; \boldsymbol{C}, \mathrm{WG} 1$

15. Graphs showing stable-isotope data for pore water collected from

Walnut Gulch boreholes and for precipitation, Sierra Vista subwatershed, Arizona

16. Graphs showing streamflow durations and sediment temperatures from sensors and from VS2DH model output, Walnut Gulch boreholes, Sierra Vista subwatershed, Arizona. A, WG2, July 19, 2002;

B, WG1, July 26-27, 2002; C, WG1, August 4, 2002 


\section{Figures-Continued}

17. Graphs showing sediment-chloride and pore-water tritium data, Banning Creek borehole BC1, Sierra Vista subwatershed, Arizona

18. Graph showing stable-isotope data for pore water collected from Banning Creek borehole BC1 and for precipitation, Sierra Vista subwatershed, Arizona.

19. Graphs showing streamflow durations and sediment temperatures from sensors and from VS2DH model output, Banning Creek borehole BC1, Sierra Vista subwatershed, Arizona. A, July 20, 2001; B, July 25, 2001; C, August 1, 2001

20. Graphs showing sediment-chloride and pore-water tritium data, Greenbush Draw boreholes, Sierra Vista subwatershed, Arizona.

$\boldsymbol{A}, \mathrm{GD} 2 ; \boldsymbol{B}, \mathrm{GD} 1$

21. Graph showing stable-isotope data for pore water collected from Greenbush Draw boreholes and for precipitation

22. Graph showing data for Walnut Gulch borehole WG4, Sierra Vista subwatershed, Arizona. A, Sediment-chloride and pore-water tritium data; $\boldsymbol{B}$, Residence time and infiltration flux, calculated from chloride data

23. Graph showing stable-isotope data for pore water collected from Walnut Gulch basin-floor boreholes WG4 and WG5 and for precipitation,

Sierra Vista subwatershed, Arizona

24. Graphs showing data for Carr Canyon borehole BF1, Sierra Vista subwatershed, Arizona. A,Sediment-chloride and pore-water tritium data; $\boldsymbol{B}$, Residence time and infiltration flux, calculated from chloride data

25. Graph showing stable-isotope data for pore water collected from basin-floor boreholes BF1 and WC4c and for precipitation, Sierra Vista subwatershed, Arizona

26. Generalized hydrogeologic section in the area of Woodcutters Wash boreholes WC4a and WC4c, Sierra Vista subwatershed, Arizona.

27. Graph showing water level in Woodcutters Wash borehole WC4c, Sierra Vista subwatershed, Arizona

28. Graphs showing data for Woodcutters Wash borehole WC4c, Sierra Vista subwatershed, Arizona. A, Sediment-chloride and pore-water tritium data; $\boldsymbol{B}$, Residence time and infiltration flux, calculated from chloride data

29. Map showing approximate distribution of annual ephemeral-stream channel recharge, 2001-2002, Sierra Vista subwatershed, Arizona

30. Graphs showing examples of sensitivity analysis results, Greenbush Draw, Sierra Vista subwatershed, Arizona, 2001-2002 


\section{Tables}

1. Tributary drainage basin geomorphic, land-cover, and soil-type characteristics, Sierra Vista subwatershed, Arizona.

2. Borehole construction and instrumentation, Sierra Vista subwatershed, Arizona

3. Sediment-chloride concentrations of borehole cuttings, Sierra Vista subwatershed, Arizona

4. Stable-isotope and tritium data for pore water samples from cores, Sierra Vista subwatershed, Arizona

5. Thermal properties of core material, Sierra Vista subwatershed, Arizona

6. Physical and hydraulic properties of core material, Sierra Vista subwatershed, Arizona.

7. Isotope and chloride data for composite precipitation samples, July 2000-April 2003, Sierra Vista subwatershed, Arizona

8. Streamflow durations at streambed-temperature sensors, Agricultural Research Service flumes, and U.S. Geological Survey streamflow-gaging stations; and distance of duration-measurement locations from the mountain front, Sierra Vista subwatershed, Arizona.

9. Streamflow characteristics and input parameters used for the infiltration-flux analytical method using heat as a tracer, Sierra Vista subwatershed, Arizona

10. Sediment properties used for the VS2DH numerical simulations, Sierra Vista subwatershed, Arizona

11. Initial and boundary conditions for the VS2DH numerical simulations,

Sierra Vista subwatershed, Arizona

12. Estimated annual ephemeral-stream channel recharge, 2001 and 2002, Sierra Vista subwatershed, Arizona

13. Sensitivity of estimated annual ephemeral-stream channel recharge to calculation parameters, 2001 and 2002, Sierra Vista subwatershed, Arizona 


\section{Conversion Factors and Datum}

\begin{tabular}{|c|c|c|}
\hline Multiply & By & To obtain \\
\hline \multicolumn{3}{|c|}{ Length } \\
\hline centimeter $(\mathrm{cm})$ & 0.3937 & inch (in.) \\
\hline meter $(\mathrm{m})$ & 3.281 & foot $(\mathrm{ft})$ \\
\hline kilometer $(\mathrm{km})$ & 0.6214 & mile (mi) \\
\hline \multicolumn{3}{|c|}{ Area } \\
\hline square kilometer $\left(\mathrm{km}^{2}\right)$ & 0.3861 & square mile $\left(\mathrm{mi}^{2}\right)$ \\
\hline \multicolumn{3}{|c|}{ Volume } \\
\hline cubic centimeter $\left(\mathrm{cm}^{3}\right)$ & 0.06102 & cubic inch $\left(\mathrm{in}^{3}\right)$ \\
\hline cubic hectometer $\left(\mathrm{hm}^{3}\right)$ & 810.7 & acre-foot (acre-ft) \\
\hline \multicolumn{3}{|c|}{ Mass } \\
\hline kilogram (kg) & 2.205 & pound, avoirdupois (lb) \\
\hline \multicolumn{3}{|c|}{ Energy } \\
\hline joule $(\mathrm{J})$ & 0.23885 & calorie \\
\hline
\end{tabular}

Temperature in degrees Celsius $\left({ }^{\circ} \mathrm{C}\right)$ may be converted to degrees Fahrenheit $\left({ }^{\circ} \mathrm{F}\right)$ as follows:

$$
{ }^{\circ} \mathrm{F}=\left(1.8 \times{ }^{\circ} \mathrm{C}\right)+32
$$

Vertical coordinate information is referenced to the North American Vertical Datum of 1988 (NAVD 88).

Horizontal coordinate information is referenced to the North American Datum of 1927 (NAD 27).

Elevation, as used in this report, refers to distance above the vertical datum.

Specific conductance is given in microsiemens per centimeter at 25 degrees Celsius $\left(\mu \mathrm{S} / \mathrm{cm}\right.$ at $\left.25^{\circ} \mathrm{C}\right)$.

Concentrations of chemical constituents in water are given either in milligrams per liter (mg/L) or micrograms per liter ( $\mu \mathrm{g} / \mathrm{L})$. Concentrations of chemical constituents in sediment are given in milligrams per kilogram $(\mathrm{mg} / \mathrm{kg})$. Activity of stable isotopes in water is given in parts per thousand $(\%)$ relative to a standard of known composition. Activity of radioactive isotopes in water is given in tritium units (TU). A tritium unit is defined as equal to 1 tritium atom per $10^{18}$ hydrogen atoms. 


\section{Abbreviations}

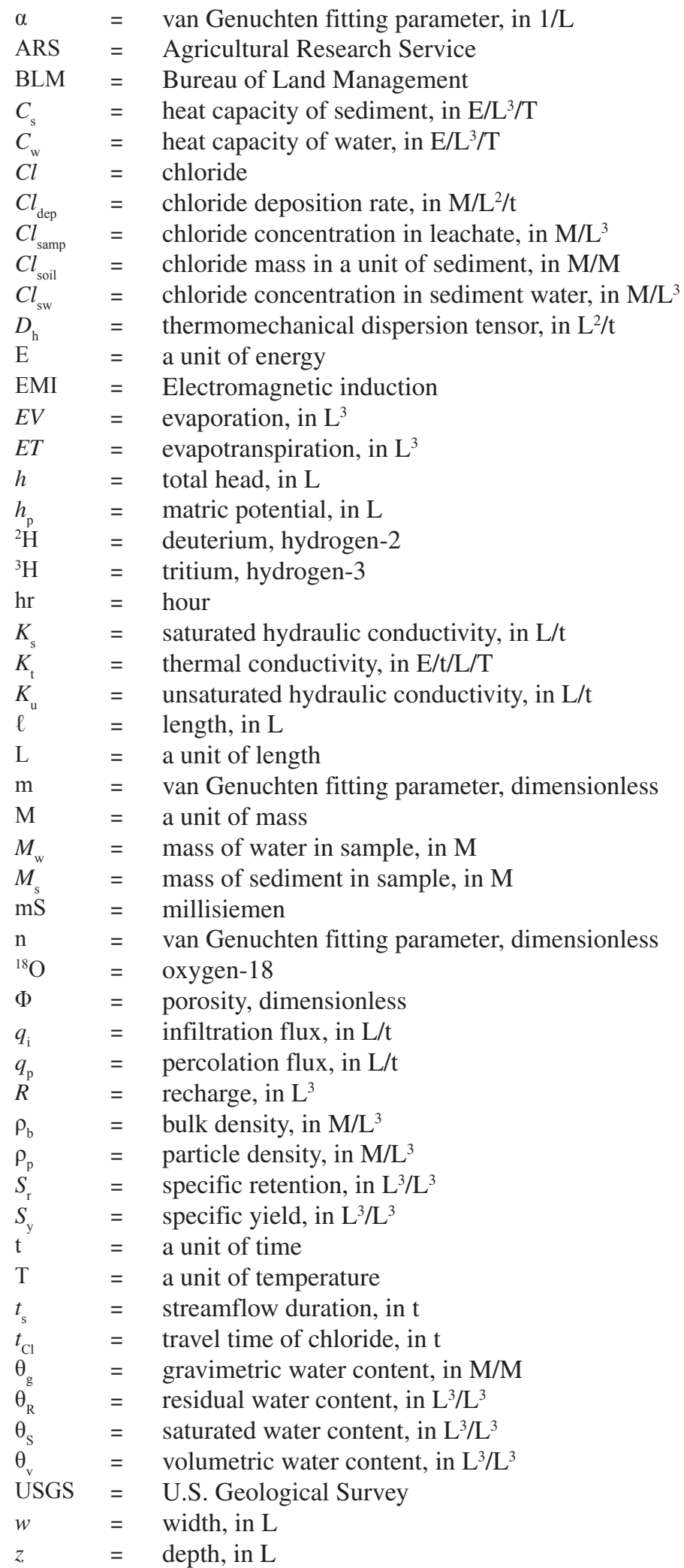




\section{ARIZONA WELL-NUMBERING SYSTEM}

WELL (D-22-22)23bbd

R. $22 \mathrm{E}$.
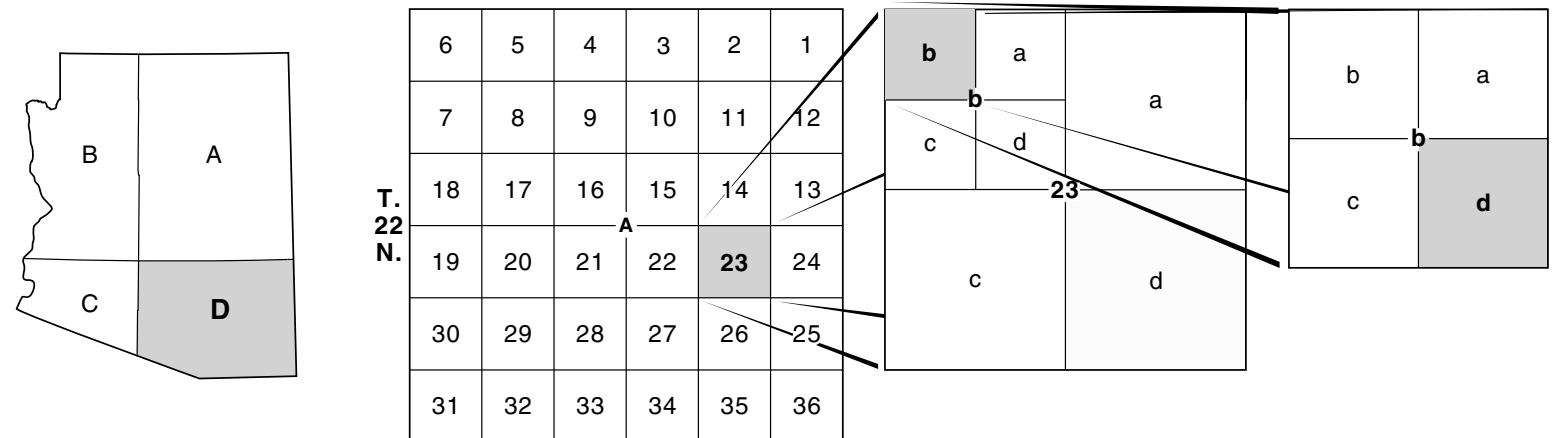

Quadrant D, Township 22 North, Range 22 East, section 23,

quarter section $b$, quarter section $b$, quarter section $d$

The well numbers used by the U.S. Geological Survey in Arizona are in accordance with the Bureau of Land Management's system of land subdivision. The land survey in Arizona is based on the Gila and Salt River meridian and base line, which divide the State into four quadrants and are designated by capital letters A, B, C, and D in a counterclockwise direction beginning in the northeast quarter. The first digit of a well number indicates the township, the second the range, and the third the section in which the well is situated. The lowercase letters $\mathrm{a}, \mathrm{b}, \mathrm{c}$, and $\mathrm{d}$ after the section number indicate the well location within the section. The first letter denotes a particular 160 -acre tract, the second the 40-acre tract and the third the 10-acre tract. These letters also are assigned in a counterclockwise direction beginning in the northeast quarter. If the location is known within the 10-acre tract, three lowercase letters are shown in the well number. Where more than one well is within a 10 -acre tract, consecutive numbers beginning with 1 are added as suffixes. In the example shown, well number (D-22-22)23bbd designates the well as being in the NW1/4, NW1/4, SE1/4, section 23, Township 22 North, and Range 22 East. 
This page left blank intentionally. 


\title{
Ephemeral-Stream Channel and Basin-Floor Infiltration and Recharge in the Sierra Vista Subwatershed of the Upper San Pedro Basin, Southeastern Arizona
}

\author{
By A.L. Coes and D.R. Pool
}

\section{Abstract}

The timing and location of streamflow in the San Pedro River are partially dependent on the aerial distribution of recharge in the Sierra Vista subwatershed. Previous investigators have assumed that recharge in the subwatershed occurs only along the mountain fronts by way of streamchannel infiltration near the contact between the lowpermeability rocks of the mountains and the basin fill. Recent studies in other alluvial basins of the Southwestern United States, however, have shown that significant recharge can occur through the sediments of ephemeral-stream channels at locations several kilometers distant from the mountains. The purpose of this study was to characterize the spatial distribution of infiltration and subsequent recharge through the ephemeral-stream channels in the Sierra Vista subwatershed.

Infiltration fluxes in ephemeral-stream channels and through the basin floor of the subwatershed were estimated using several methods. Data collected during the drilling and coring of 16 boreholes included physical, thermal, and hydraulic properties of sediments; chloride concentrations of sediments; and pore-water stable-isotope values and tritium activity. Surface and subsurface sediment temperatures were continuously measured at each borehole.

Twelve boreholes were drilled in five ephemeralstream channels to estimate infiltration within ephemeralstream channels. Active infiltration was verified to at least 20 meters at 11 of the 12 borehole sites on the basis of low sediment-chloride concentrations, high soil-water contents, and pore-water tritium activity similar to that of presentday precipitation. Consolidated sediments at the twelfth site prevented core recovery and estimation of infiltration. Analytical and numerical methods were applied to determine the surface infiltration flux required to produce the observed sediment-temperature fluctuations at six sites. Infiltration fluxes were determined for summer ephemeral flow events only because no winter flows were recorded at the sites during the monitoring period.

Four boreholes were drilled in the basin floor to estimate infiltration in areas between ephemeral-stream channels. Infiltration fluxes through the basin floor ranged from less than 1 centimeter to 6 centimeters per year. At a site in semiconsolidated to consolidated basin-fill conglomerate, the long-term infiltration fluxes were very low (less than 1 centimeter per year). Chloride, tritium, and stable-isotope data indicate long periods of no net deep downward percolation flux beneath the basin floor. At a site in unconsolidated to semiconsolidated basin-fill sand and gravel, infiltration fluxes were high ( 2 to 6 centimeters per year). Chloride, tritium, and stable-isotope data indicate active infiltration to 8 meters and a decrease in infiltration below 8 meters. The change in the infiltration rate below 8 meters is controlled by an increase in the silt and clay content of the sediment.

Ephemeral-stream channel recharge for the entire subwatershed was estimated by upscaling the calculated infiltration fluxes and weighting the fluxes by streamflow duration, evaporation, and transpiration. In contrast to previous assumptions, recharge from ephemeral-streamflow infiltration occurs not only near the mountain fronts, but also along significant lengths of ephemeral-stream channels. Although most of the ephemeral streams in the subwatershed flow less than a few days per year, the available streamflow quickly infiltrates past depths where it is available for evapotranspiration. This water likely stays in the unsaturated zone until it is vertically displaced by infiltrated water from subsequent streamflows and eventually recharges the regional aquifer. Ephemeral-stream channel infiltration during 2001 and 2002 was estimated to account for about 12 to 19 percent of the estimated average annual recharge in the Sierra Vista subwatershed.

\section{Introduction}

An improved understanding of the recharge distribution in the Sierra Vista subwatershed of the Upper San Pedro ground-water basin was needed to better estimate the effects of ground-water withdrawals on natural discharges from the system through base flow and riparian vegetation. The interception of ground water that would flow naturally from recharge areas to the San Pedro River by pumping could result 
in decreased streamflows in the river. The timing and location of the reduced streamflow are dependant on the location of the withdrawal wells, the hydraulic properties of the aquifer, and the aerial distribution of recharge. Recharge occurring downgradient of withdrawal wells is less likely to be captured by withdrawal wells and more likely to discharge to the river. Improved understanding of recharge distributions will enable local, State, and Federal organizations and agencies to effectively manage available water resources to meet water needs in the basin. Toward this goal, the U.S. Geological Survey (USGS), in cooperation with the Bureau of Land Management (BLM) and the Upper San Pedro Partnership, has collected and analyzed hydrologic information describing infiltration and recharge, ground- and surface-water interactions, water-level and ground-water storage trends, and geometry and lithology of the aquifer. This report documents the results of investigations of recharge by stream-channel and basin-floor infiltration, potentially important recharge mechanisms in the basin.

The Sierra Vista subwatershed encompasses about 2,460 square kilometers $\left(\mathrm{km}^{2}\right)$ in the southern part of the San Pedro River Basin in southeastern Arizona (fig. 1) and extends about $43 \mathrm{~km}$ north from the international boundary with Mexico to near Fairbank. The subwatershed is part of a broad alluvial basin and is bounded on the west by the Huachuca Mountains and on the east by the Mule Mountains and the Tombstone Hills. Elevations of the basin floor vary from about 1,150 to $1,310 \mathrm{~m}$; mountain elevations range from about 1,520 to $2,900 \mathrm{~m}$.

The San Pedro River flows northward through the subwatershed (fig. 1). The river and its associated groundwater system support a corridor of riparian vegetation that hosts several endangered species and is an important habitat for American migratory birds. About $64 \mathrm{~km}$ of the river and riparian area has been protected by designation as the San Pedro Riparian National Conservation Area (SPRNCA; fig. 1), and is managed by the BLM.

Sierra Vista, with a population of 37,775 in 2000, is the largest city in the subwatershed (U.S. Census Bureau, 2000). By 2020, the population of Sierra Vista is projected to be 52,571 (Arizona Department of Economic Security, 1997), an increase of 39 percent. Populations of other cities in the subwatershed in 2000 were 6,090 in Bisbee, 1,751 in Huachuca City, and 1,504 in Tombstone (U.S. Census Bureau, 2000).

Ground water is the primary source for municipal, domestic, livestock, and irrigation water needs in the subwatershed, and ground-water withdrawals have increased as the population has increased. The magnitude of the effect that these increasing withdrawals have on the river and its associated riparian vegetation is proportional to the amount and distribution of recharge to the ground-water system. Ground-water pumping intercepts part of the natural flow of water through the aquifer before the water reaches natural discharge areas. To better understand and predict the effects of historic, present, and future ground-water withdrawals on natural discharge, the spatial and temporal variability of recharge rates must be adequately understood.
Previous investigators have assumed that recharge in the Sierra Vista subwatershed occurs only near the mountain fronts (Freethey, 1982; Corell and others, 1996; Goode and Maddock, 2000). They envisioned recharge occurring as stream-channel infiltration near the contact of the lowpermeability rocks of the mountains and the basin fill. Recent studies in other alluvial basins of the Southwestern United States, however, have shown that significant recharge can occur through the sediments of stream channels far from the mountains (Blasch and others, 2000; Izbicki and others, 2000; Constantz and others, 2003). Direct infiltration of precipitation through the floors of alluvial basins in the Southwest has been considered negligible because of high evapotranspiration and low precipitation. The possibility of significant recharge along ephemeral-stream channels far from the mountains or through direct infiltration on the basin floor places uncertainty on the adequacy of previous recharge concepts for use in the development of water-management plans.

\section{Purpose and Scope}

This report presents estimates of infiltration and recharge through the ephemeral-stream channels and the basin floor of the Sierra Vista subwatershed, and documents the data collection and analysis. Data resulted from drilling and coring of 16 boreholes and included physical, hydraulic, and thermal properties of sediment; chloride concentrations of sediment; pore-water stable-isotope values and tritium activity; neutronsoil moisture and electromagnetic induction (EMI) logs; and continuous sediment-temperature profiles and water levels during 2001 and 2002. Unsaturated-zone infiltration processes at six ephemeral-stream channel sites were modeled to estimate infiltration and percolation fluxes during and following streamflows.

\section{Acknowledgments}

The authors thank the BLM, Fort Huachuca, Arizona State Land Department, city of Tombstone, and several private land owners for permission to drill observation boreholes on their property and to visit the boreholes repeatedly over a period of several years. Bruce Gungle, John Fleming, James Leenhouts, Cory Angeroth, James Callegary, Dan Evans, Kyle Blasch, Marcella Ripich, and Ester Muset (USGS), and Anastasia Olander and Sharon Einloth (University of Arizona) assisted in the drilling of the observation boreholes and the associated collection of cuttings and cores. Dr. Ty P. Ferré and Dr. Arthur Warrick (University of Arizona) provided laboratory space and equipment for analysis of sediment properties. Sheri Musil (University of Arizona) provided laboratory expertise for analysis of sediment properties. Anastasia Olander (University of Arizona) completed the analysis of sediment properties as part of her Master's research. Chris Eastoe (University of Arizona) provided tritium analyses of precipitation samples. The U.S. Department of Agriculture Agricultural Research Service (ARS) Southwest Watershed Research Center provided provisional streamflow data for sites in the ARS Walnut Gulch Experimental Watershed. 


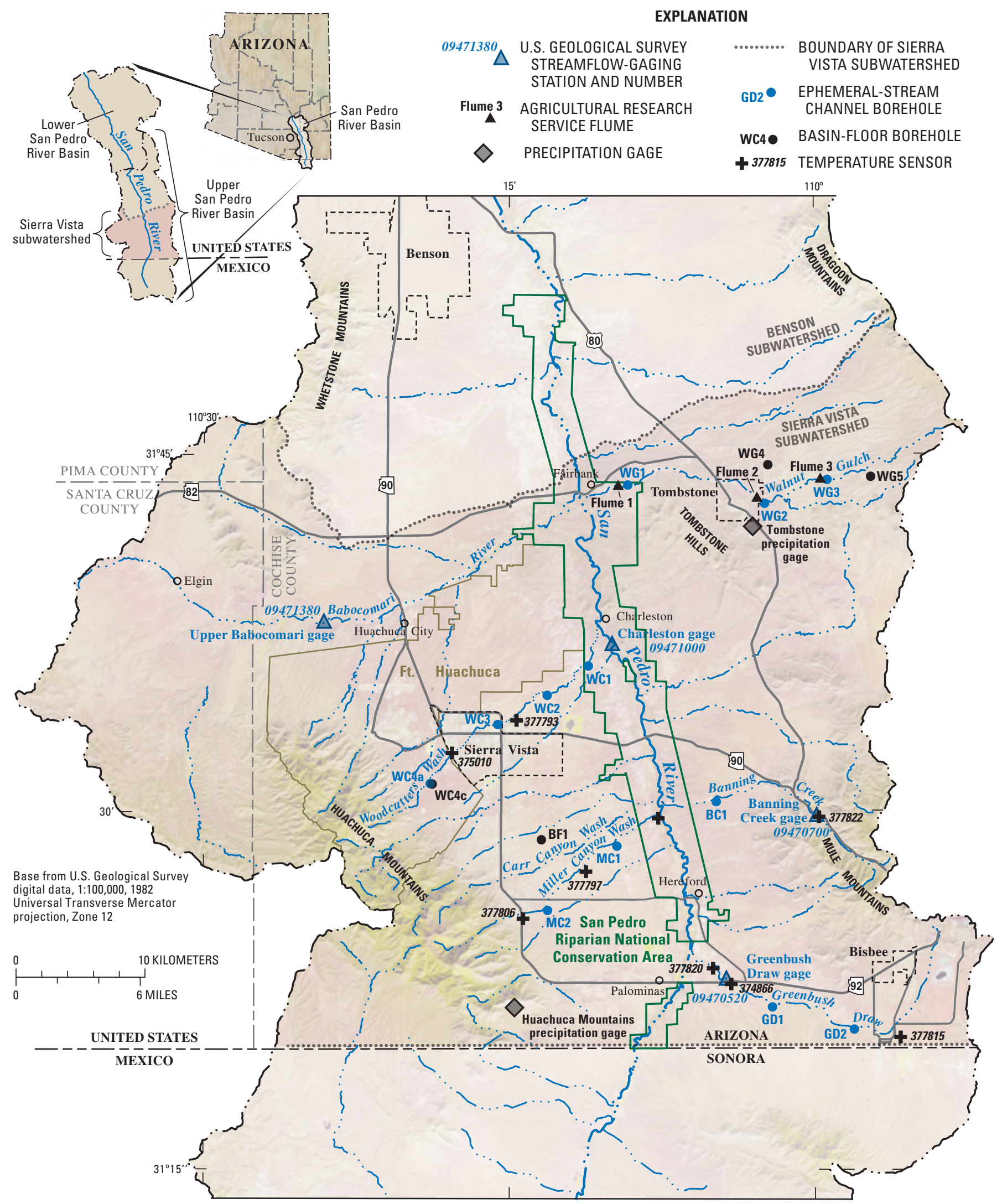

Figure 1. Sierra Vista subwatershed, locations of boreholes, temperature sensors, Agricultural Research Service flumes, U.S. Geological Survey streamflow-gaging stations, and precipitation gages, southeastern Arizona and northeastern Sonora, Mexico. 
Ephemeral-Stream Channel and Basin-Floor Infiltration and Recharge in the Sierra Vista Subwatershed, Arizona

\section{Land Cover}

Major types of land cover include grassland (32.6 percent), desert scrub (28.8 percent), mesquite woodland (13.5 percent), and urban (5.3 percent; fig. 2; U.S. Environmental Protection Agency, 2003). The remaining 19.8 percent includes oak woodlands ( 15.2 percent) and forest ( 2.2 percent) in and near the mountains and the riparian ( 0.9 percent) and agricultural ( 0.8 percent) areas near the San Pedro and Babocomari Rivers (U.S. Environmental Protection Agency, 2003). Although the urban percentage is small, most of the urban land is concentrated in the northcentral part of the subwatershed.

The hydrologic influence of each major land-cover type on the portion of precipitation that is transported to ephemeral stream channels has not been qualified. Some basic assumptions can, however, be inferred. Runoff produced in mesquite woodlands and desert scrub areas most likely is a small percentage of precipitation because leaves and branches can intercept precipitation and the high soil temperatures and low soil-moisture contents and potentials result in high soil permeability. Runoff from grasslands likely is a greater percentage of precipitation because the lower soil temperatures and higher soil-moisture contents result in lower soil permeability than that in mesquite woodlands and desert scrub areas. Urban areas produce the highest percentage of runoff into stream channels because of large expanses of impermeable surfaces that prevent soil infiltration and engineered drainage infrastructures that concentrate and focus runoff.

\section{Soils}

The distribution of soil types in the Sierra Vista subwatershed is dominated by lithic, loamy, and fine paleosoils near the mountains, and clayey soils and calcium carbonate soils along the lower reaches of the watersheds (fig. 3; U.S. Environmental Protection Agency, 2003). Narrow ribbons of sandy loam typically lie along ephemeral-stream channels; sandy, clayey, and calcium carbonate soils typically lie between the channels. Calcium carbonate soils dominate areas below the mountains across much of the eastern part of the subwatershed. A wedge of calcium carbonate soils also extends nearly to the mountains in the central part of the study area west of the San Pedro River. The southwestern part of the subwatershed is dominated by clayey and sandy soils.

Soil types can also have a strong influence on the fraction of precipitation that is transported to ephemeral-stream channels. Sandy loam soils likely are the most permeable, enabling direct infiltration of precipitation and limiting runoff into stream channels. Clayey soils can limit deep infiltration where they underlie channels. Soils having secondary calcium carbonate are less permeable and enhance runoff. Shallow lithic soils underlain by bedrock or rocky layers promote runoff into stream channels and limit infiltration.

\section{Precipitation}

The subwatershed climate is arid to semiarid. Precipitation data are available from the Western Regional Climate Center (2003) for a gage in Tombstone at an elevation of 1,384 m, from 1905 to 2002; and for a gage in the Huachuca Mountains at an elevation of 1,692 m, from 1956 to 2002 (fig.s 1 and 4). Historically, July through September are the wettest months; precipitation during this period averages $21 \mathrm{~cm}$ at the Tombstone gage and $27 \mathrm{~cm}$ at the Huachuca Mountains gage. Precipitation from October through March averaged 12 and $23 \mathrm{~cm}$ at the Tombstone and Huachuca Mountains gages, respectively; and precipitation from April through June averaged less than $3 \mathrm{~cm}$ at both gages.

Long-term monitoring indicates that annual precipitation rates were above average before about 1940 and during the early to mid-1980s, below average from about 1940 to 1980, and about average after the mid-1980s (Pool and Coes, 1999). Trends in seasonal precipitation, however, are different from trends in annual precipitation. From 1956 to 1997, winter (November-February) precipitation rates increased while wetseason (June-October) precipitation rates decreased (Pool and Coes, 1999).

Estimates of recharge in this report are biased by precipitation immediately prior to and during the monitoring period. Precipitation during the year that preceded the monitoring period, 2000, was average $(36 \mathrm{~cm})$ at the Tombstone gage, but wetter than average $(78 \mathrm{~cm})$ at the Huachuca Mountains gage (fig. 4). During 2000, the Huachuca Mountains gage recorded an abnormally wet June and August, and October was the wettest month on record $(32 \mathrm{~cm})$. Precipitation during the monitoring period, 2001 and 2002, was dominated by dry winters and slightly drier than average summers (fig. 4). During July through September of 2001 and 2002, precipitation was below average at the Tombstone gage (16 and $17 \mathrm{~cm}$, respectively) and slightly above average at the Huachuca Mountains gage ( $29 \mathrm{~cm}$ during both years). Precipitation in October through June of 2001 and 2002 was below average at both gages.

\section{Surface-Water Drainage System}

The San Pedro River, an intermittent stream, drains the Sierra Vista subwatershed (fig. 1). Annual and wet-season runoff in the San Pedro River have declined since the mid1910s, probably as a result of reduced precipitation duration and intensity, increased vegetation, and increased streamflow infiltration along ephemeral reaches of the river and its tributary streams (Pool and Coes, 1999). Base flow in the river is lowest during the summer when rates of near-stream ground-water withdrawals by wells and phreatophytes are highest. Long-term records indicate that summer base flows have been declining since 1937 (Pool and Coes, 1999). 


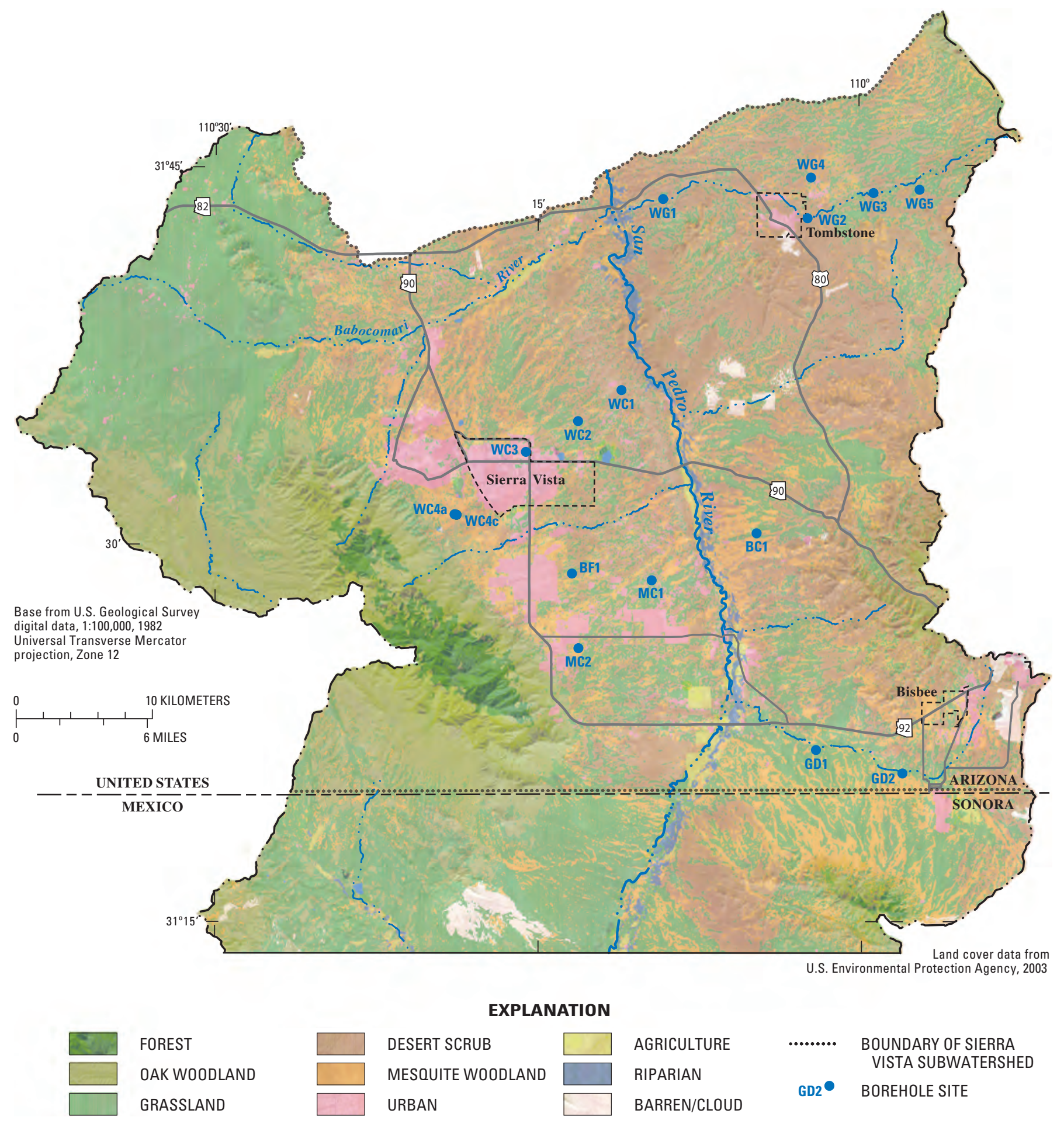

Figure 2. Land cover and locations of borehole sites, Sierra Vista subwatershed, Arizona. 


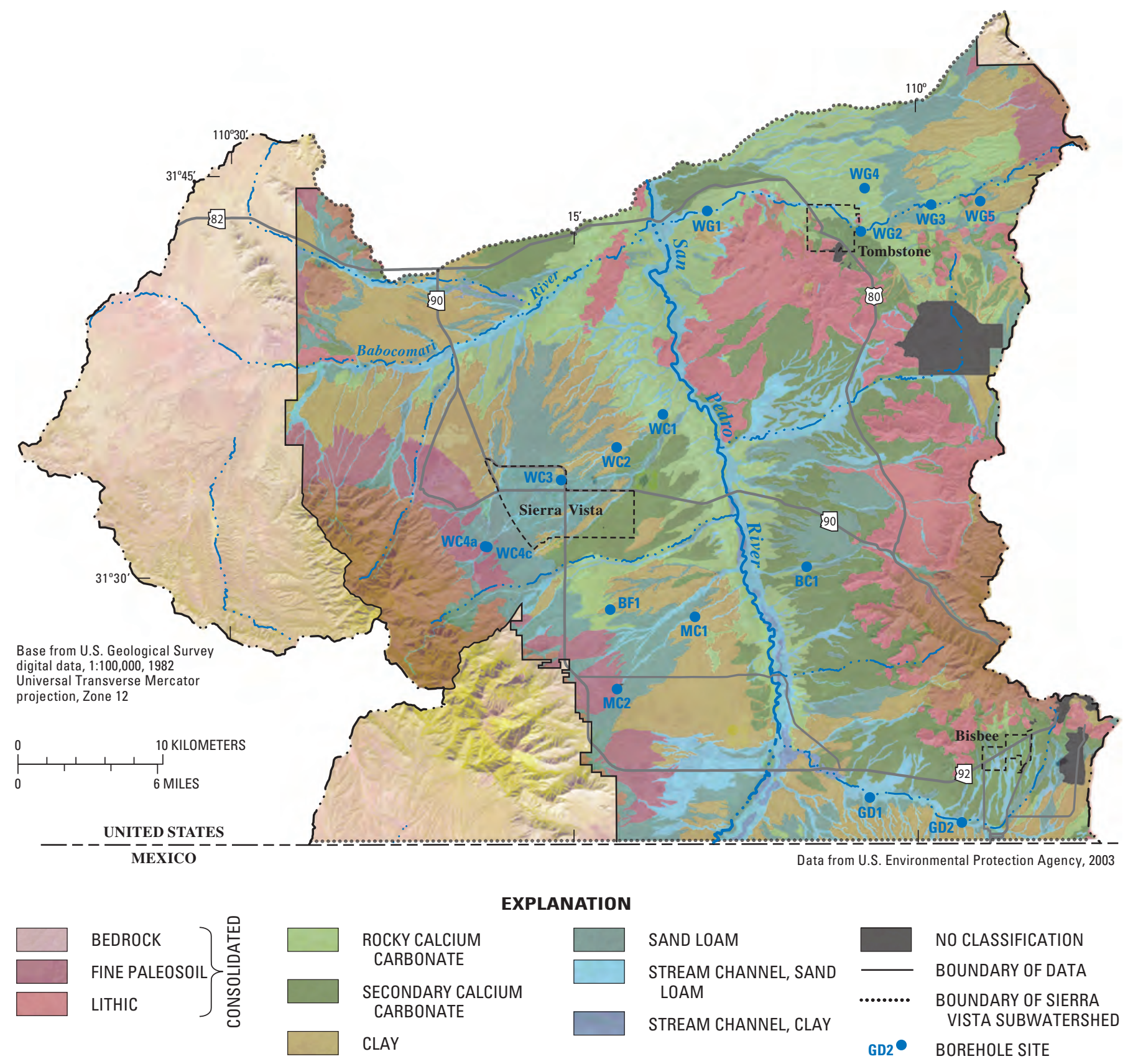

Figure 3. Soil type and locations of borehole sites, Sierra Vista subwatershed, Arizona. 


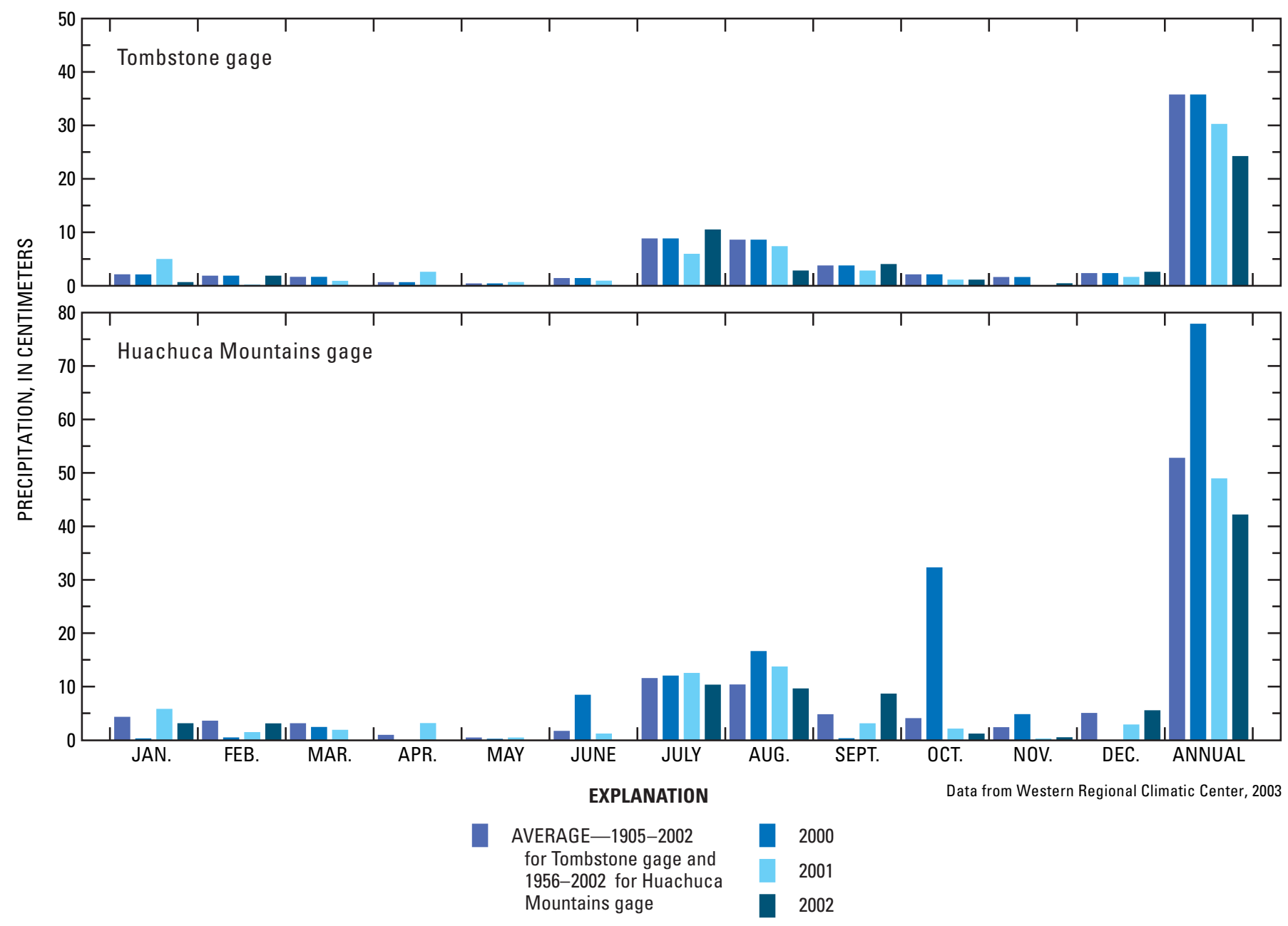

Figure 4. Monthly and annual precipitation, Tombstone and Huachuca Mountains gages, Sierra Vista subwatershed, Arizona.

Tributaries of the San Pedro River are ephemeral except for the Babocomari River, which is perennial in some areas (fig. 5). Flow occurs only in direct response to rainfall or snowmelt. The amount of flow is generally dependant on the spatial distribution and intensity of precipitation, the runoff characteristics of the channel, and the associated drainage area. The temporal distribution of flow in ephemeral-stream channels in the arid Southwest generally is the result of monthly, annual, and decadal oscillations in precipitation frequency (Redmond and Koch, 1991; Webb and Betancourt, 1992).

The majority of tributaries to the San Pedro River originate in the mountains bounding the subwatershed and coalesce downstream to form higher-ordered ephemeralstream channels (fig. 5). Tributaries generally have narrow, shallow channels, close to the mountain fronts, that become wide, deep channels below a knickpoint. Channels draining the east side of the Huachuca Mountains typically have long and narrow drainage areas and few channels coalescing downstream; the southern tributaries become wider and less channelized towards the San Pedro River. Channels draining the west side of the Mule Mountains typically have much wider drainage areas and multiple channels coalescing downstream.

\section{Ground-Water System}

The ground-water system of the Sierra Vista subwatershed has been described by previous investigators (Brown and others, 1966; Pool and Coes, 1999); an overview is given here. The primary aquifer in the subwatershed is within basin fill that overlies crystalline and sedimentary rocks. Secondary aquifers comprise stream alluvium beneath the flood plains of the San Pedro and Babocomari Rivers, and pre-basin fill and limestones that crop out in the mountains and hills surrounding the subwatershed. Ground water generally flows from recharge areas to discharge areas along the San Pedro and Babocomari Rivers. Ground water also discharges from the aquifer through ground-water withdrawals, evapotranspiration, springs, and ground-water underflow to the north. 


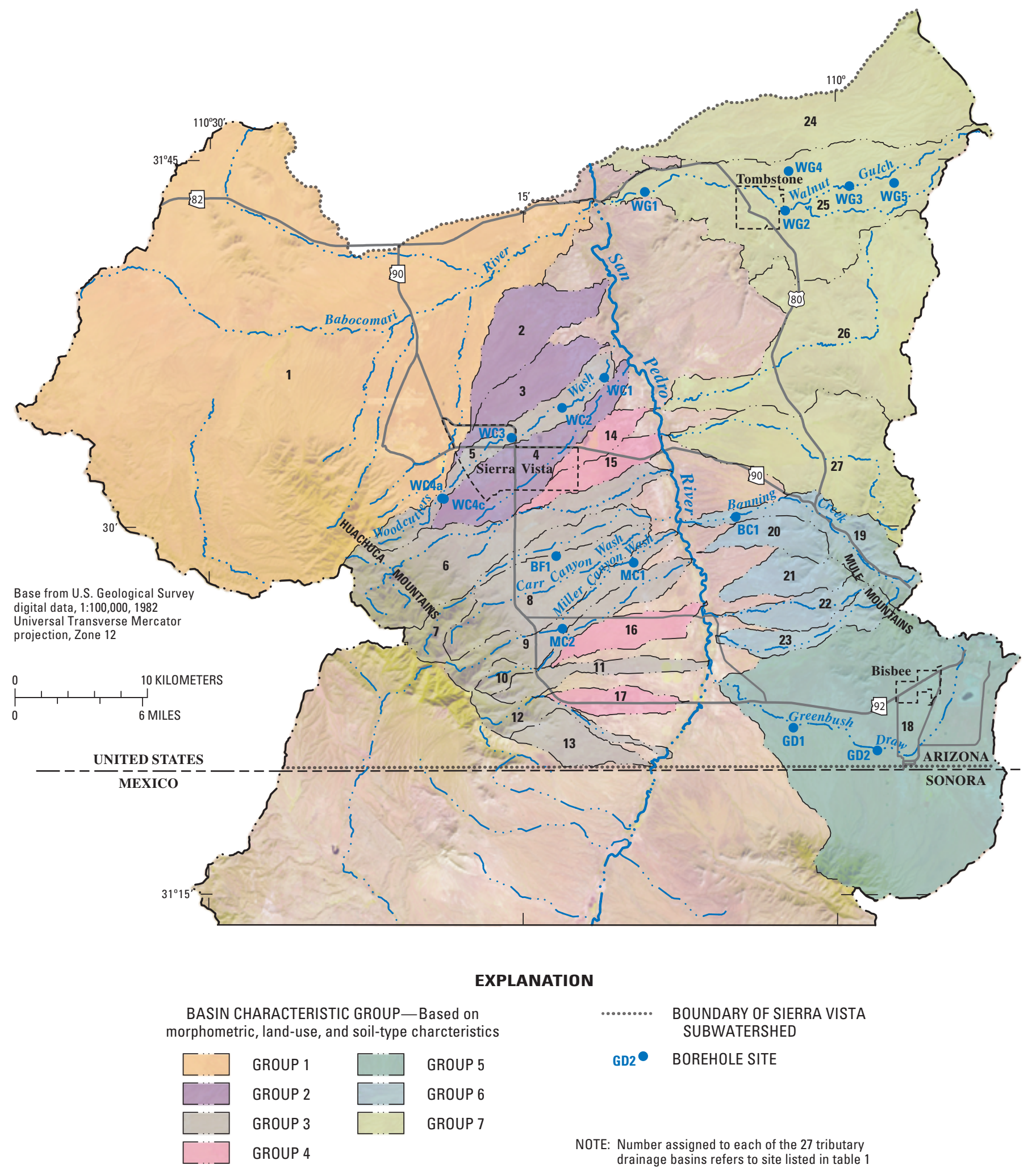

Figure 5. Tributary drainage basins and locations of borehole sites, Sierra Vista subwatershed, Arizona and northeastern Sonora, Mexico. 


\section{Aquifers}

The Pantano Formation, a consolidated to semiconsolidated conglomerate, overlies the bedrock in the subwatershed and is the oldest of the basin sediments. The formation probably is greater than $900 \mathrm{~m}$ thick in some areas (Halverson, 1984; Gettings and Houser, 1995). The Pantano Formation is a locally important water-bearing unit, as it yields water through fractures to many wells in the Sierra Vista area (Pool and Coes, 1999).

The basin fill that overlies the Pantano Formation has been divided into upper and lower units on the basis of compositional, textural, and depositional differences. The lower unit consists of partially cemented interbedded gravel, sand, silt, and clay that is often described as conglomerate, and ranges in thickness from about 45 to $90 \mathrm{~m}$ (Pool and Coes, 1999). Permeability of the lower unit varies because of variation in sediment size, sorting, and cementation (Brown and others, 1966). The upper unit consists of poorly cemented gravel, sand, silt, and clay (Brown and others, 1966), and is generally less than $120 \mathrm{~m}$ thick (Pool and Coes, 1999). The upper unit includes a permeable fan-gravel facies near the mountain fronts that grades to a poorly permeable silt and clay facies with interspersed sand and caliche beds near the basin center (Pool and Coes, 1999). Between Sierra Vista and the San Pedro River, and between Hereford and Highway 90, the upper unit is primarily a saturated confining bed of silt and clay (Pool and Coes, 1999). The upper and lower basin-fill units are the major water-yielding units in the Sierra Vista subwatershed and constitute the basin-fill aquifer. Water levels in the basin-fill aquifer range from less than $1 \mathrm{~m}$ to as much as $165 \mathrm{~m}$ (USGS unpublished data).

Terrace deposits of clay, silt, sand, and gravel overlie the upper basin fill in most areas. These deposits form a veneer of stream alluvium that is thin near the mountain fronts but is as much as 15 to $30 \mathrm{~m}$ thick in erosional channels that parallel the San Pedro River (Pool and Coes, 1999). Older terrace deposits include lakebed deposits of silt, clay, and marl (Haynes, 1968) that are local confining layers where they occur near the San Pedro River; erosion has removed most of the lakebed deposits along tributaries (Pool and Coes, 1999). Younger terrace deposits include stream alluvium along the San Pedro River and some of its tributaries (Pool and Coes, 1999). The older deposits are rarely saturated outside of the flood plains of the San Pedro and Babocomari Rivers. The younger deposits are saturated in some areas near the San Pedro and Babocomari Rivers and along some tributaries near the base of the mountains and are locally important water-bearing units (Pool and Coes, 1999).

Recent stream alluvium lies along the San Pedro and Babocomari Rivers. Stream alluvium deposited prior to the entrenchment of the San Pedro River consists of clay, silt, and fine sand interbedded with coarse sand and gravel, and is as much as $6 \mathrm{~m}$ deep and $1.5 \mathrm{~km}$ wide (Pool and Coes, 1999). Stream alluvium deposited after the entrenchment of the San Pedro River consists of sand and gravel and is less than
$6 \mathrm{~m}$ deep and only about $1 \mathrm{~km}$ wide (Pool and Coes, 1999). The post-entrenchment stream alluvium is highly permeable; the pre-entrenchment stream alluvium is less permeable (Pool and Coes, 1999). The pre- and post-entrenchment stream alluvium forms a long, narrow, shallow aquifer along the San Pedro River that is referred to as the flood-plain aquifer. Water levels in the flood-plain aquifer range from less than $1 \mathrm{~m}$ to as much as $6 \mathrm{~m}$ below land surface (USGS unpublished data). Water levels in this aquifer are a major influence on river discharges and show seasonal trends reflecting cycles of surface-water runoff and evapotranspiration.

\section{Recharge Mechanisms}

Historically, recharge to the basin-fill aquifer in the Sierra Vista subwatershed was thought to primarily occur near the mountain fronts through ephemeral-stream channel infiltration of runoff from the relatively impermeable rocks of the mountains. Previous conceptual models of the groundwater flow system included annual recharge rates of 15 to $23 \mathrm{hm}^{3} / \mathrm{yr}$, all of which was distributed within about $1.5 \mathrm{~km}$ of the mountains (Freethey, 1982; Corell and others, 1996; Goode and Maddock, 2000). Infiltration and recharge could, however, be distributed along much greater lengths of the channels. Recent studies (Blasch and others, 2000; Izbicki and others, 2000; Constantz and others, 2003) have shown that significant recharge can occur through the beds of ephemeral streams far from mountain fronts. In the Sierra Vista subwatershed, Corell and others (1996) estimated that infiltration along the length of Greenbush Draw contributed about $1.20 \mathrm{hm}^{3} / \mathrm{yr}$ of recharge. Goodrich and others (2004) estimated that a $6.8-\mathrm{km}$ reach of Walnut Gulch contributed about 0.14 to $0.47 \mathrm{hm}^{3}$ of recharge in 1999 and about 0.13 to $0.37 \mathrm{hm}^{3}$ of recharge in 2000. The occurrence of similar rates of recharge along other major ephemeral streams would result in significant alterations to the pre-existing conceptual model of recharge distributions in the subwatershed. Recharge through direct infiltration of precipitation through the basin floor is thought to occur rarely because of high evaporation, low precipitation, and water use by desert vegetation in the semiarid Southwest (Anderson and others, 1992; Scott and others, 2000). Rare basin-floor recharge could, however, be a significant source of recharge during extended periods of high precipitation and low evapotranspiration.

The occurrence of significant recharge along the lengths of ephemeral stream channels or through the basin floor, however, would not result in increased estimates of average annual basin-wide recharge rates. Water-budget analysis requires that estimates of recharge rates be maintained to balance inflows and outflows. The change would simply be in the conceptual model of recharge distribution: less concentrated recharge near the mountains and more extensive recharge downstream in tributary channels.

Previous recharge estimates for the Sierra Vista subwatershed have generally assumed that recharge rates are constant with time. Trends in seasonal and annual precipitation 
(Pool and Coes, 1999), however, likely result in long-term variations in recharge rates. Water-chemistry data for the Sierra Vista subwatershed and the adjacent Tucson Basin indicate that a greater percentage of precipitation infiltrates during winter streamflow than during summer streamflow

(Gallaher, 1979; Keith, 1981; Pool and Coes, 1999). Rates of summer streamflow have varied randomly from year to year, but rates of winter streamflow vary over decadal periods with Pacific Ocean climate indicators (Cayan and Webb, 1992; Webb and Betancourt, 1992; Cayan and others, 1999; McCabe and Dettinger, 1999).

\section{Ground-Water Flow System}

Ground water in the basin-fill aquifer is transmitted from recharge areas to discharge areas primarily through the sands and gravels of the upper and lower basin-fill units. Near the mountain fronts, shallow bedrock and relatively impermeable sediments support perched aquifers. Silt and clay layers within the upper and lower basin-fill units on the west side of the subwatershed split ground-water flow in the regional aquifer into deep and shallow flow systems (Pool and Coes, 1999). Exceptions to the regional directions of ground-water flow exist near the Sierra Vista-Fort Huachuca area, where withdrawals have removed ground water from aquifer storage and altered pre-development ground-water flow paths (Pool and Coes, 1999).

Post-development discharge from the basin-fill aquifer in the Sierra Vista subwatershed occurs primarily as ground-water withdrawals, discharge to the San Pedro and Babocomari Rivers (base flow), and evapotranspiration. Ground-water withdrawals in the subwatershed began in about 1940 and peaked in the early 1980s at about $18.5 \mathrm{hm}^{3} / \mathrm{yr}$ (Freethey, 1982; Corell and others, 1996). Withdrawals declined to about $13.5 \mathrm{hm}^{3} / \mathrm{yr}$ by 1991 (Corell and others, 1996). Post-development discharge to streams is about $7.4 \mathrm{hm}^{3} / \mathrm{yr}$, and post-development evapotranspiration is estimated to be about $7.0 \mathrm{hm}^{3} / \mathrm{yr}$ (Freethey, 1982). About 3.7 to $4.9 \mathrm{hm}^{3} / \mathrm{yr}$ discharges from the subwatershed as underflow through basin fill and stream alluvium in the Fairbank area (Freethey, 1982; Corell and others, 1996). In addition, a small amount of ground water discharges as springs near the San Pedro River.

Pool and Coes (1999) identified four types of long-term water-level changes in the Sierra Vista subwatershed. The first type is periodic decline and recovery of water levels near the mountains related to variations in precipitation and rates of recharge. The second is a decline of 0.2 to more than $0.3 \mathrm{~m} / \mathrm{yr}$ in the Sierra Vista-Fort Huachuca area caused by ground-water withdrawals. The third is a regional decline of 0.1 to $0.2 \mathrm{~m} / \mathrm{yr}$ during 1940 through the mid-1960s or early 1980s followed by a period of no decline or slight recovery. This regional decline could be caused by variations in recharge rates or regional response to incision of the San Pedro River. The fourth type of long-term water-level change is recovery near the San Pedro River after the mid-1980s that is probably due to a decrease in agricultural ground-water withdrawals.

\section{Methods of Investigation}

Multiple methods were used to estimate infiltration through ephemeral-stream channels and the basin floor in the Sierra Vista subwatershed. Information gathered through unsaturated-zone borehole drilling and monitoring was used to better describe infiltration through the unsaturated zone. Tritium data were used to describe the extent to which water has moved through the unsaturated zone since the 1950s. Ratios of the stable isotopes of oxygen and hydrogen were used to identify evaporative and seasonal signatures of pore water. The distribution of chloride in the subsurface was used to identify active or inactive recharge areas, and where possible, was balanced to determine infiltration fluxes and water residence times. The transport of heat with infiltrating water was used to quantify infiltration rates from individual ephemeral streamflow events.

\section{Field and Laboratory Methods}

To characterize ephemeral-stream channel and basinfloor recharge in the Sierra Vista subwatershed, 12 tributary sites and 4 intertributary sites were chosen for intensive unsaturated-zone data collection. At each site, a borehole was drilled into the subsurface and sediment cuttings and cores were collected. Of the 16 boreholes, 15 were completed with casing for subsurface monitoring. Sediment textures were described in the field, and sediment-chloride concentrations were measured. Sediment cores were measured for hydraulic, physical, and thermal properties; pore-water stable-isotopes values; and tritium activity. Twelve of the completed boreholes were instrumented for continuous monitoring of sediment temperature. Ground-water levels of saturated intervals were continuously monitored in three of the completed boreholes.

\section{Borehole Site Selection}

Tributary and intertributary borehole locations were chosen by using a multistep approach. First, the Automated Geospatial Watershed Assessment (AGWA) tool (Miller and others, 2002), an extension to the Environmental Systems Research Institute's ArcView version 3.0, was used to delineate the drainage basins of the major tributaries of the San Pedro River (fig. 5). For each basin, the main channel length, main channel slope, total basin area, mean basin elevation, basin perimeter, basin length, major land use, and major soil type were quantified using the Xtools and Spatial Analyst extensions to ArcView (table 1). The basins were then divided into seven groups on the basis of similar morphometric, land-use, and soil-type characteristics (fig. 5). Twelve tributary sites were chosen in five drainage basins that represent four of the seven groups: four sites in Woodcutters Wash, two sites in Miller Canyon Wash, two sites in Greenbush Draw, one site in Banning Creek, and three sites in Walnut Gulch. In addition, four intertributary (basin floor) sites were chosen in three drainage basins: two sites in Walnut Gulch, one site in Woodcutters Wash, and one site in Carr Canyon. 
Table 1. Tributary drainage basin geomorphic, land-cover, and soil-type characteristics, Sierra Vista subwatershed, Arizona [Group numbers correspond with groups shown on figure $5 ; \mathrm{km}$, kilometers; $\mathrm{m} / \mathrm{km}$, meters per kilometer; $\mathrm{km}^{2}$, square kilometers; ND, not determined]

\begin{tabular}{|c|c|c|c|c|c|c|c|c|c|}
\hline $\begin{array}{l}\text { Iden- } \\
\text { tifier } \\
\text { (see } \\
\text { fig. 5) }\end{array}$ & Tributary name & $\begin{array}{c}\text { Main } \\
\text { channel } \\
\text { length }^{1} \\
(\mathbf{k m})\end{array}$ & $\begin{array}{c}\text { Main } \\
\text { channel } \\
\text { slope } \\
(\mathrm{m} / \mathrm{km})\end{array}$ & $\begin{array}{c}\text { Total } \\
\text { basin } \\
\text { area } \\
\left(\mathrm{km}^{2}\right)\end{array}$ & $\begin{array}{c}\text { Mean } \\
\text { basin } \\
\text { eleva- } \\
\text { tion } \\
(\mathrm{m})\end{array}$ & $\begin{array}{c}\text { Basin } \\
\text { peri- } \\
\text { meter } \\
(\mathbf{k m})\end{array}$ & $\begin{array}{c}\text { Basin } \\
\text { length } \\
(\mathrm{km}) \\
\end{array}$ & $\begin{array}{c}\text { Major land cover } \\
\text { (percentage) }\end{array}$ & Major soil type ${ }^{2}$ (percentage) \\
\hline & \multicolumn{9}{|c|}{ Group 1} \\
\hline 1 & Babocomari River & 47.8 & 7.9 & 528.0 & 1,512 & 187.5 & 48.2 & Grassland (48.3) & ND \\
\hline 2 & Unnamed Wash 1 & 15.4 & 10.9 & 41.8 & 1,288 & 39.2 & 14.4 & Desert scrub (44.1) & Loam (27.9) \\
\hline 3 & Graveyard Gulch & 14.4 & 12.3 & 30.9 & 1,310 & 35.1 & 12.7 & Desert scrub (38.3) & Loam (49.7) \\
\hline 4 & Coyote Wash & 20.7 & 13.8 & 50.3 & 1,370 & 44.8 & 19.4 & Urban (37.9) & Loam (54.8) \\
\hline & \multicolumn{9}{|c|}{ Group 3} \\
\hline 5 & Woodcutters Wash & 23.0 & 13.9 & 37.5 & 1,434 & 54.7 & 32.6 & Desert scrub (26.7) & Loam (34.4) \\
\hline 9 & Miller Canyon Wash & 16.2 & 20.5 & 32.8 & 1,693 & 48.1 & 27.9 & Forest (25.2) & Loam (23.3) \\
\hline 10 & Hunter Canyon Wash & 15.5 & 19.1 & 24.1 & 1,478 & 43.0 & 23.9 & Grassland (38.5) & Loam (32.9) \\
\hline 11 & Stump Canyon Wash & 14.6 & 19.5 & 18.5 & 1,624 & 36.3 & 16.4 & Grassland (35.3) & Clay (41.5) \\
\hline 12 & Ash Canyon Wash & 12.9 & 23.7 & 17.5 & 1,818 & 37.5 & 15.6 & Oak woodland (67.2) & Paleosoil (13.3) \\
\hline 13 & $\begin{array}{l}\text { Brown-Bob } \\
\text { Thompson Wash }\end{array}$ & 9.5 & 23.3 & 21.0 & 1,536 & 25.7 & 11.0 & Grassland (38.4) & Loam (31.9) \\
\hline & \multicolumn{9}{|c|}{ Group 4} \\
\hline 14 & Lewis Springs Wash & 12.1 & 12.0 & 13.0 & 1,300 & 22.0 & 12.5 & Desert scrub (46.7) & Secondary calcium carbonate (71.8) \\
\hline 15 & Bakarich-McCool Wash & 11.8 & 12.6 & 18.5 & 1,320 & 28.5 & 13.2 & Desert scrub (52.0) & Secondary calcium carbonate (58.8) \\
\hline 19 & Banning Creek & 8.6 & 15.6 & 41.3 & 1,655 & 47.8 & 21.2 & Desert scrub (46.4) & Secondary calcium carbonate (11.0) \\
\hline 20 & Unnamed Wash 2 & 10.1 & 24.1 & 19.0 & 1,436 & 24.7 & 13.3 & Desert scrub (51.7) & Secondary calcium carbonate $(59.4)$ \\
\hline 21 & Stagg Ranch Wash & 10.5 & 25.7 & 21.9 & 1,456 & 25.0 & 10.2 & Desert scrub (63.3) & Secondary calcium carbonate (53.8) \\
\hline 22 & Little Dry Creek & 10.6 & 23.4 & 19.2 & 1,466 & 27.6 & 13.4 & Desert scrub (40.5) & Secondary calcium carbonate (61.1) \\
\hline 23 & Spring Creek & 11.4 & 22.9 & 22.6 & 1,527 & 33.3 & 14.6 & Desert scrub (43.3) & Loam (29.0) \\
\hline & \multicolumn{9}{|c|}{ Group 7} \\
\hline 24 & Willow Wash & 20.9 & 16.0 & 130.8 & 1,531 & 76.6 & 23.1 & Grassland (40.1) & Rocky calcium carbonate (29.0) \\
\hline 25 & Walnut Gulch & 26.5 & 12.1 & 152.1 & 1,411 & 86.1 & 34.1 & Desert scrub (57.6) & Rocky calcium carbonate (35.2) \\
\hline 26 & Government Draw & 17.8 & 7.6 & 148.4 & 1,399 & 80.8 & 20.5 & Desert scrub (65.0) & Lithic (26.4) \\
\hline 27 & $\begin{array}{l}\text { High Knolls Canyon } \\
\text { Wash }\end{array}$ & 18.7 & 12.5 & 98.9 & 1,443 & 56.5 & 29.4 & Desert scrub (45.2) & Lithic (43.6) \\
\hline
\end{tabular}

${ }^{1}$ From the mountain front.

${ }^{2}$ U.S. Environmental Protection Agency, 2003. 


\section{Borehole Drilling and Completion}

Unsaturated-zone boreholes were drilled and completed in January 2001 and November-December 2001 (table 2). All boreholes were drilled using the ODEX air-hammer method, also known as the under-reamer method (Driscoll, 1986; Hammermeister and others, 1986). This drilling method minimized disturbance of the formation near the borehole, and enabled collection of representative cuttings and cores at predetermined intervals. Boreholes were drilled to depths of less than $30.0 \mathrm{~m}$ and were either 15.2 or $20.3 \mathrm{~cm}$ in diameter. At each borehole, drill cuttings were collected every $0.3 \mathrm{~m}$, and 0.6-m-long ( 24 inches) cores were collected at differing intervals using a $10.2-\mathrm{cm}$-diameter piston core barrel. The 0.6-m-long core barrel was lined with three 15.2-cm-long sleeve liners and two 7.6-cm-long sleeve liners. Upon core collection, each of the liners was immediately capped, taped, plastic wrapped, and placed in an aluminum pouch, which was then heat sealed, following the procedure described by Hammermeister and others (1986), to preserve the integrity of each core sample.

Of the 16 boreholes, 15 were completed to enable future subsurface monitoring (table 2). Permission was not granted from the land owner to complete the borehole at WC2. Each borehole was completed with 5.1-cm-diameter schedule-40 polyvinyl chloride (PVC) pipe. Twelve of the boreholes were completed with solid-walled PVC and capped at the bottom and top. During drilling, three of the boreholes intercepted saturated intervals and were completed with solid-walled PVC above the saturated interval and a $1.5-\mathrm{m}$ section of slotted PVC spanning the unsaturated/saturated interface. The annular space of the 12 boreholes completed with solid-walled PVC was filled with a mixture of cuttings from the boreholes and sand. The annular space of the three boreholes completed with slotted PVC was filled with gravel in the slotted interval, bentonite above the slotted interval, and a mixture of cuttings and sand above the bentonite. Surface casing consists of 10.2-cm-diameter schedule-80 PVC pipe from above land surface to 0.9 to $1.5 \mathrm{~m}$ depth around the $5.1-\mathrm{cm}$-diameter PVC casing. The uppermost 0.9 to $1.5 \mathrm{~m}$ of annular space between the surface casing and the borehole was filled with cement. The surface casing was capped with a watertight, locking, aluminum cap. Completion of the 15 boreholes with PVC casing resulted in 12 unsaturated-zone monitoring access points and 3 wells. Use of the term "borehole" is retained, however, for convenience of discussion in this report.

\section{Sediment Analysis}

\section{Cuttings}

Cuttings from each borehole were visually described for grain-size distribution at 0.3-m intervals (fig. 6). Cuttings from three boreholes were also analyzed in the laboratory for particle-size distribution (fig. 6).
Sediment-chloride concentrations of borehole cuttings (except for borehole WG5) collected at 0.3-m intervals were determined in the field (table 3). A subsample of cuttings representative of each $0.3-\mathrm{m}$ interval was sieved to obtain particles less than $2 \mathrm{~mm}$ in diameter. Fifty grams of the sieved subsample was mixed well with $50 \mathrm{~mL}$ of deionized water and allowed to settle. The chloride concentration of the leachate was then measured using an Orion chloride-specific electrode, Model 96-17 (Thermo Electron Corporation, 2000). This electrode measures chloride concentrations of 1.8 to $35,500 \mathrm{mg} / \mathrm{L}$ with a reproducibility of \pm 2 percent. The electrode was calibrated in the field at the beginning of each set of measurements; calibration was checked every 1 to 2 hours. Chloride is reported in milligrams of chloride per kilogram of soil (mg/kg; $\mathrm{MCl}$, in $\mathrm{M} / \mathrm{M})$ :

$$
M_{C l}=C l_{\text {samp }} \frac{V_{W}}{M_{S}},
$$

where

$$
\begin{aligned}
C l_{\text {samp }} & =\text { chloride concentration of leachate }\left[\mathrm{M} / \mathrm{L}^{3}\right], \\
\mathrm{VW} & =\text { volume of deionized water in leachate }\left[\mathrm{L}^{3}\right], \\
\mathrm{Ms} & =\text { mass of sediment in leachate }[\mathrm{M}] .
\end{aligned}
$$

\section{Cores}

Cores were analyzed to determine pore-water stableisotope values and tritium activity; thermal, physical, and hydraulic properties; and particle-size distributions. Pore water was extracted and analyzed for the stable isotopes of oxygen and hydrogen at the USGS Isotope Fractionation Project Laboratory in Reston, Virginia (table 4). Pore water was extracted and analyzed for tritium activity at the USGS Water-Quality Laboratory in Menlo Park, California (table 4). The precision of individual tritium measurements is a function of the volume of water extracted from the core material and ranged from \pm 0.2 tritium units (TU) for moist cores to $\pm 5.0 \mathrm{TU}$ for an extremely dry core. Thermal properties (specific heat and thermal conductivity, at field soil-water content; table 5) were measured at the USGS Hydrologic Research Laboratory in Sacramento, California, using a dual-needle, line-heat source probe and a ThermoLink measurement system (Campbell and others, 1991; Decagon Devices, Inc., 1999). 
Table 2. Borehole construction and instrumentation, Sierra Vista subwatershed, Arizona

[km, kilometers; m, meters; cm, centimeters; do., ditto; NA, not applicable; NC, not completed. Surface TidbiT: Y, yes; N, no]

\begin{tabular}{|c|c|c|c|c|c|c|c|c|c|c|c|c|c|c|}
\hline \multirow[b]{2}{*}{$\begin{array}{l}\text { Borehole } \\
\text { identifier }\end{array}$} & \multirow[b]{2}{*}{$\begin{array}{c}\text { Borehole } \\
\text { identification } \\
\text { number }\end{array}$} & \multirow{2}{*}{$\begin{array}{c}\text { Distance } \\
\text { down- } \\
\text { stream } \\
\text { from } \\
\text { mountain } \\
\text { front } \\
\text { (km) }\end{array}$} & \multirow{2}{*}{$\begin{array}{l}\text { Approx- } \\
\text { imate } \\
\text { channel } \\
\text { width } \\
\text { (m) } \\
\end{array}$} & \multicolumn{8}{|c|}{ Construction information } & \multicolumn{3}{|c|}{ Instrumentation information } \\
\hline & & & & $\begin{array}{l}\text { End drill } \\
\text { date }\end{array}$ & $\begin{array}{l}\text { Bore- } \\
\text { hole } \\
\text { diam- } \\
\text { eter } \\
\text { (cm) }\end{array}$ & $\begin{array}{l}\text { Bore- } \\
\text { hole } \\
\text { depth } \\
(\mathrm{m})\end{array}$ & $\begin{array}{l}\text { Casing } \\
\text { diam- } \\
\text { eter } \\
\text { (cm) }\end{array}$ & $\begin{array}{c}\text { Casing } \\
\text { depth } \\
(\mathrm{m})\end{array}$ & Opening type & $\begin{array}{c}\text { Depth to } \\
\text { top of } \\
\text { opening } \\
\text { (m) }\end{array}$ & $\begin{array}{c}\text { Depth to } \\
\text { bottom of } \\
\text { opening } \\
(\mathrm{m})\end{array}$ & $\begin{array}{l}\text { Trans- } \\
\text { ducer } \\
\text { depth } \\
\text { (m) }\end{array}$ & $\begin{array}{l}\text { Sur- } \\
\text { face } \\
\text { Tidbit }\end{array}$ & $\begin{array}{l}\text { Down-hole TidbiT depths } \\
\text { (m) }\end{array}$ \\
\hline \multicolumn{15}{|c|}{ Ephemeral-stream channel boreholes } \\
\hline$\overline{\mathrm{BC} 1}$ & $(\mathrm{D}-22-22) 23 \mathrm{bbd}$ & 3.9 & 4 & $01-17-2001$ & 20.3 & 26.3 & 5.1 & 26.3 & None & NA & NA & NA & $\mathrm{Y}$ & $1.5,3.0,4.6,6.1,7.6,9.1,12.2$ \\
\hline GD1 & (D-24-23)06dbd & 12.4 & 14 & $11-30-2001$ & 15.2 & 19.5 & do. & 19.5 & None & NA & NA & NA & $\mathrm{N}$ & $1.5,3.0,6.1,9.1$ \\
\hline GD2 & (D-24-23)14aba & 5.6 & 2 & $11-29-2001$ & do. & 28.2 & do. & 28.2 & None & NA & NA & NA & $\mathrm{Y}$ & $1.5,3.0,4.6,6.1,7.6,9.1,12.2$ \\
\hline MC1 & (D-22-21)36bad & 7.1 & 4 & $11-18-2001$ & do. & 23.0 & do. & 23.0 & None & NA & NA & NA & $\mathrm{Y}$ & $1.5,3.0,4.6,6.1,9.1$ \\
\hline MC2 & (D-23-21)bca2 & 0 & 2 & $11-20-2001$ & do. & 16.0 & do. & 16.0 & None & NA & NA & NA & $\mathrm{N}$ & $1.5,3.0,4.6,6.1,7.6,9.1,12.2$ \\
\hline WC1 & (D-21-21)14dbc1 & 16.4 & 10 & 01-14-2001 & 20.3 & 9.4 & do. & 9.4 & None & NA & NA & NA & $\mathrm{Y}$ & $1.5,3.0,4.6,6.1,7.6,9.1$ \\
\hline $\mathrm{WC} 1$ & (D-21-21)14dbc2 & do. & do. & do. & do. & do. & do. & 8.5 & Slotted PVC & 7.3 & 8.8 & 8.8 & $\mathrm{~N}$ & NA \\
\hline WC2 & (D-21-21)28bbb & 12.3 & 22 & $01-12-2001$ & do. & 12.5 & $\mathrm{NC}$ & $\mathrm{NC}$ & $\mathrm{NC}$ & $\mathrm{NC}$ & $\mathrm{NC}$ & NA & $\mathrm{N}$ & NA \\
\hline WC3 & (D-21-20)36caa & 7.2 & 8 & $11-09-2001$ & 15.2 & 22.6 & 5.1 & 22.6 & None & NA & NA & NA & $\mathrm{N}$ & $1.5,3.0,4.6,6.1,7.6,9.1,12.2$ \\
\hline WC4a & $(\mathrm{D}-22-20) 16 \mathrm{abc} 1$ & .4 & 0.5 & 01-10-2001 & 20.3 & 12.5 & do. & 12.7 & None & NA & NA & NA & $\mathrm{Y}$ & $1.5,3.0,4.6,6.1,7.6,9.1,12.2$ \\
\hline WC4a & $(\mathrm{D}-22-20) 16 \mathrm{abc} 2$ & do. & do. & do. & do. & do. & do. & 5.3 & Slotted PVC & 3.8 & 5.3 & 4.6 & $\mathrm{~N}$ & NA \\
\hline WG1 & $(\mathrm{D}-20-21) 01 \mathrm{aba}$ & 25.6 & 31 & $11-11-2001$ & 15.2 & 23.0 & do. & 23.0 & None & NA & NA & NA & $\mathrm{N}$ & $1.5,3.0,4.6,6.1,9.1$ \\
\hline WG2 & (D-20-22)01bdc & 13.2 & 13 & $11-16-2001$ & do. & 12.2 & do. & 11.4 & None & NA & NA & NA & $\mathrm{N}$ & $1.5,3.0,4.6$ \\
\hline WG3 & D-19-23)33aad & 7.2 & 2 & $11-15-2001$ & do. & 12.3 & do. & 12.3 & None & NA & NA & NA & $\mathrm{N}$ & NA \\
\hline \multicolumn{15}{|c|}{ Basin-floor boreholes } \\
\hline BF1 & (D-22-21)32dad & NA & NA & $12-01-2001$ & 15.2 & 15.8 & 5.1 & 15.1 & None & NA & NA & NA & $\mathrm{Y}$ & $1.5,3.0,4.6,6.1,7.6,9.1,12.2$ \\
\hline $\mathrm{WC} 4 \mathrm{c}$ & (D-22-20)16acb & NA & NA & 01-08-2001 & 20.3 & 12.5 & do. & 12.5 & Slotted PVC & 4.3 & 5.8 & 9.1 & $\mathrm{Y}$ & $1.5,3.0,4.6,6.1,7.6,9.1,12.2$ \\
\hline WG4 & (D-19-22)36abb & NA & NA & $11-12-2001$ & 15.2 & 13.4 & do. & 13.4 & None & NA & NA & NA & $\mathrm{N}$ & NA \\
\hline WG5 & (D-19-23)36dbc & NA & NA & $11-13-2001$ & do. & 12.3 & do. & 12.3 & None & NA & NA & NA & $\mathrm{N}$ & NA \\
\hline
\end{tabular}


A. WC4a

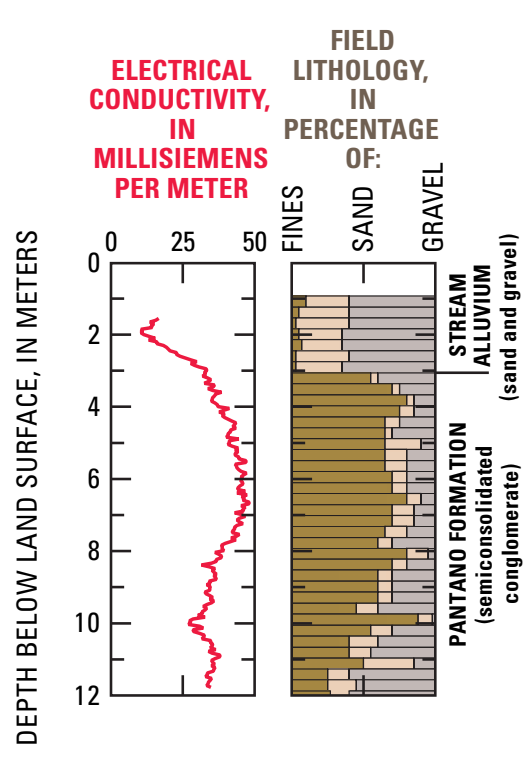

C. WC2

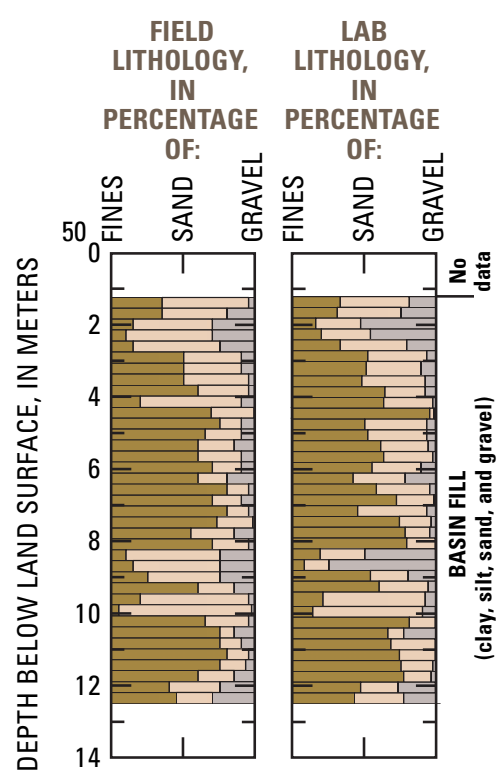

B. WC3
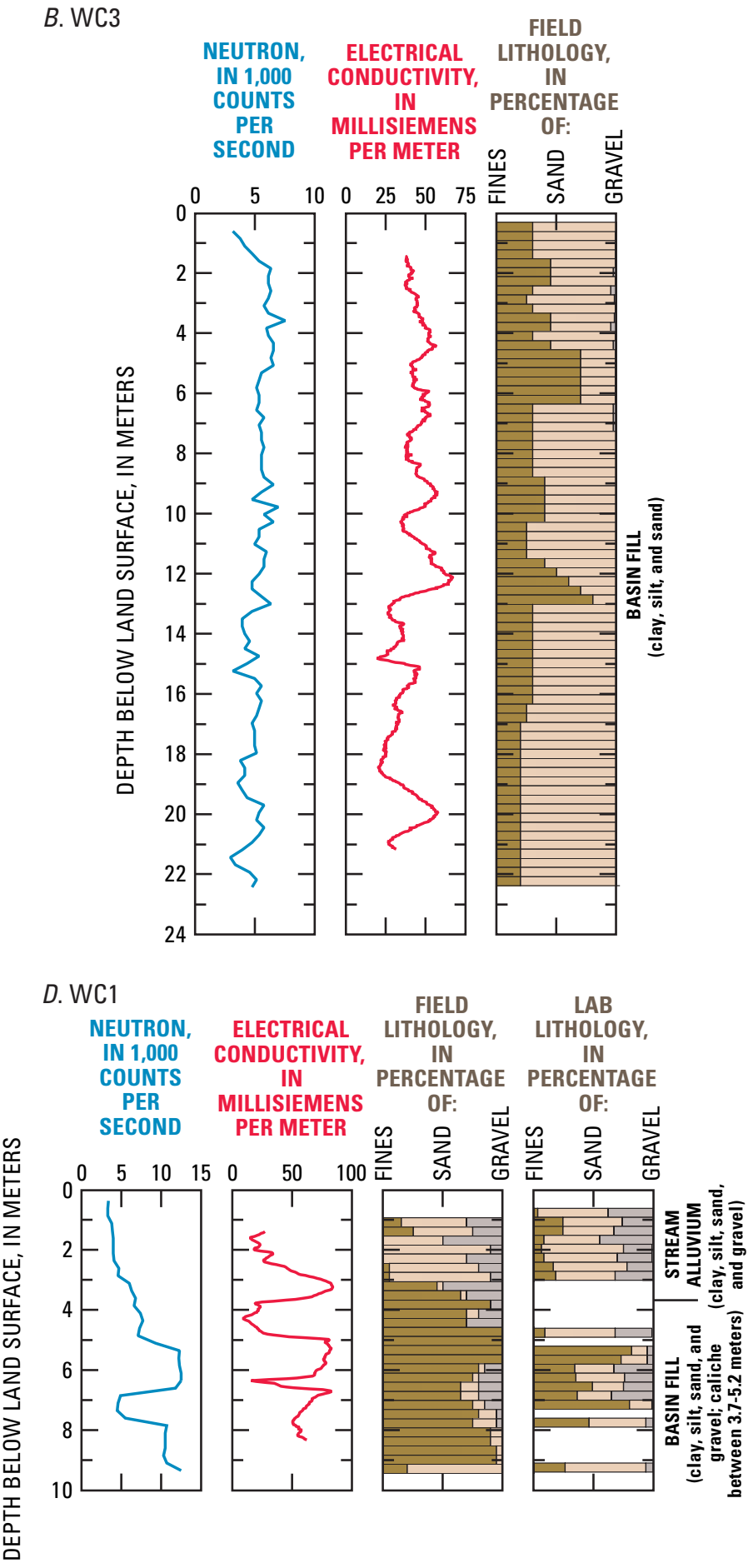

Figure 6. Neutron soil-moisture, electrical conductivity, field grain-size, and laboratory grain-size data for boreholes, Sierra Vista

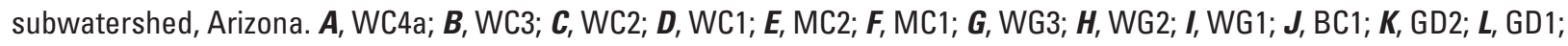
$\boldsymbol{M}$, WG4; $\boldsymbol{N}$, WG5; $\boldsymbol{O}, \mathrm{BF} 1 ; \boldsymbol{P}, \mathrm{WC4C}$. 
E. MC2

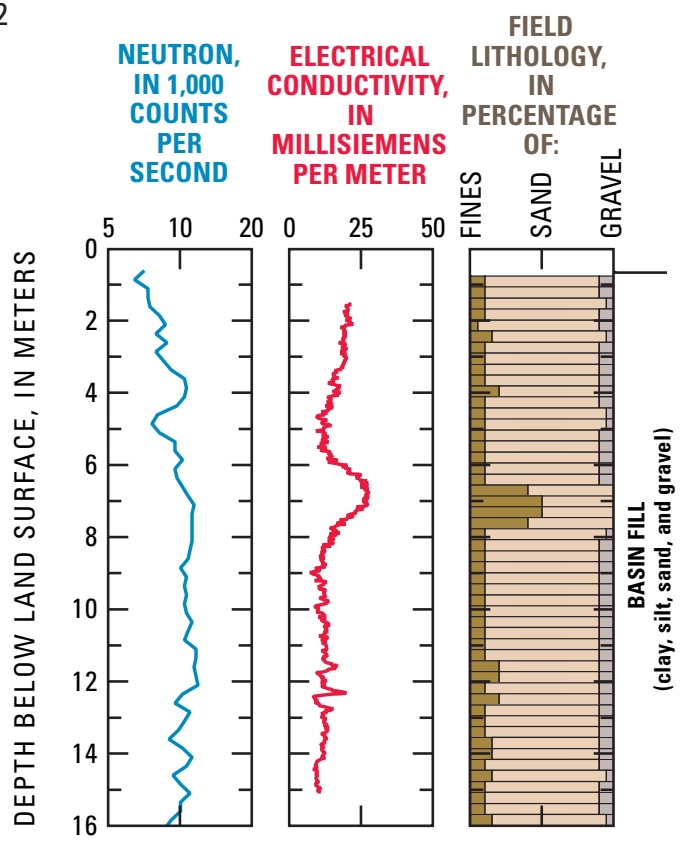

G. WG3

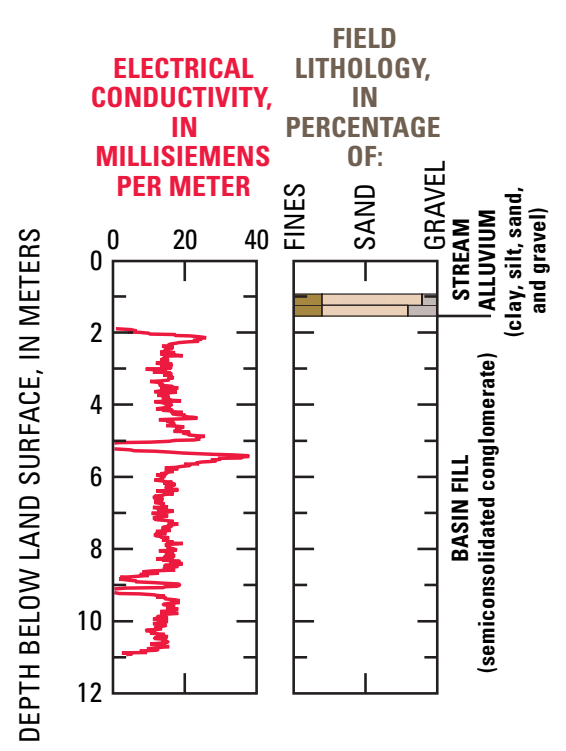

F. MC1

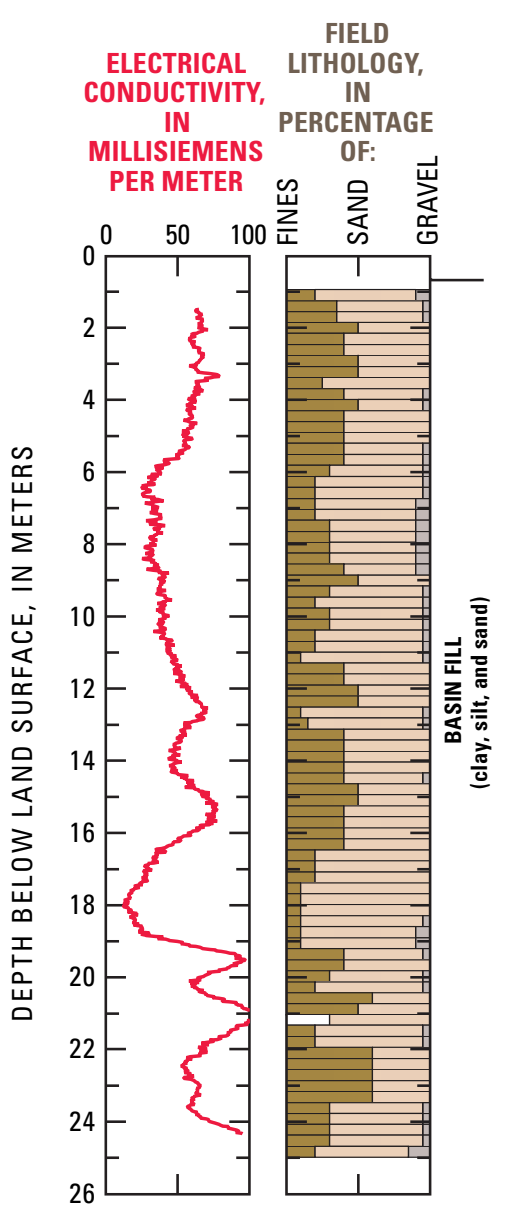

H. WG2

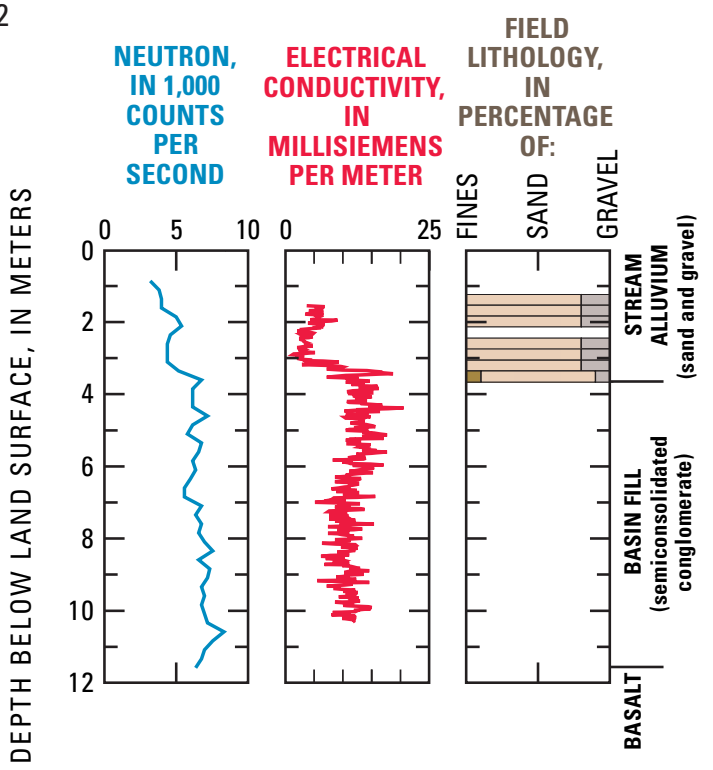

Figure 6. Continued. 
I. WG1

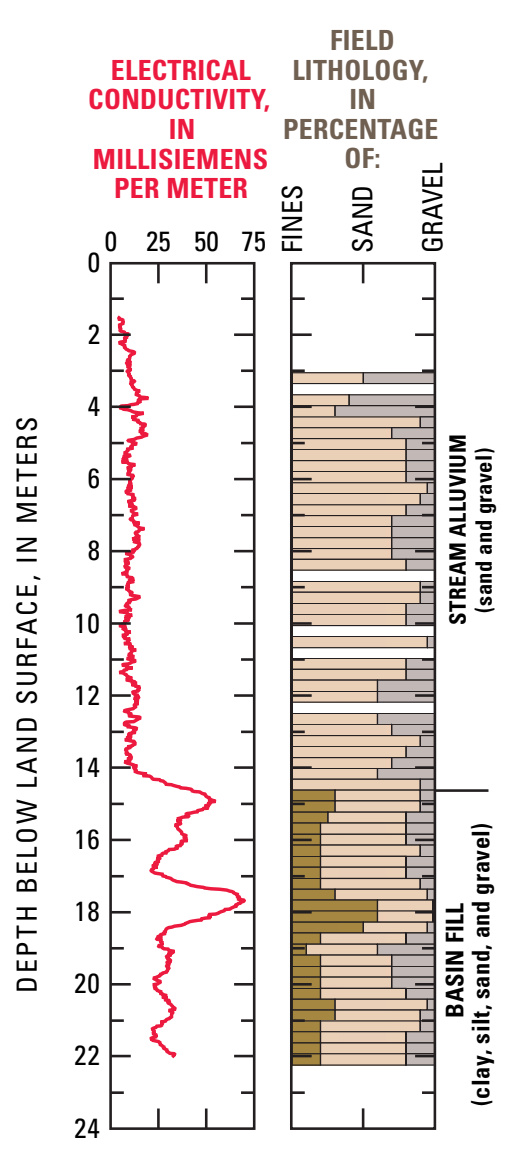

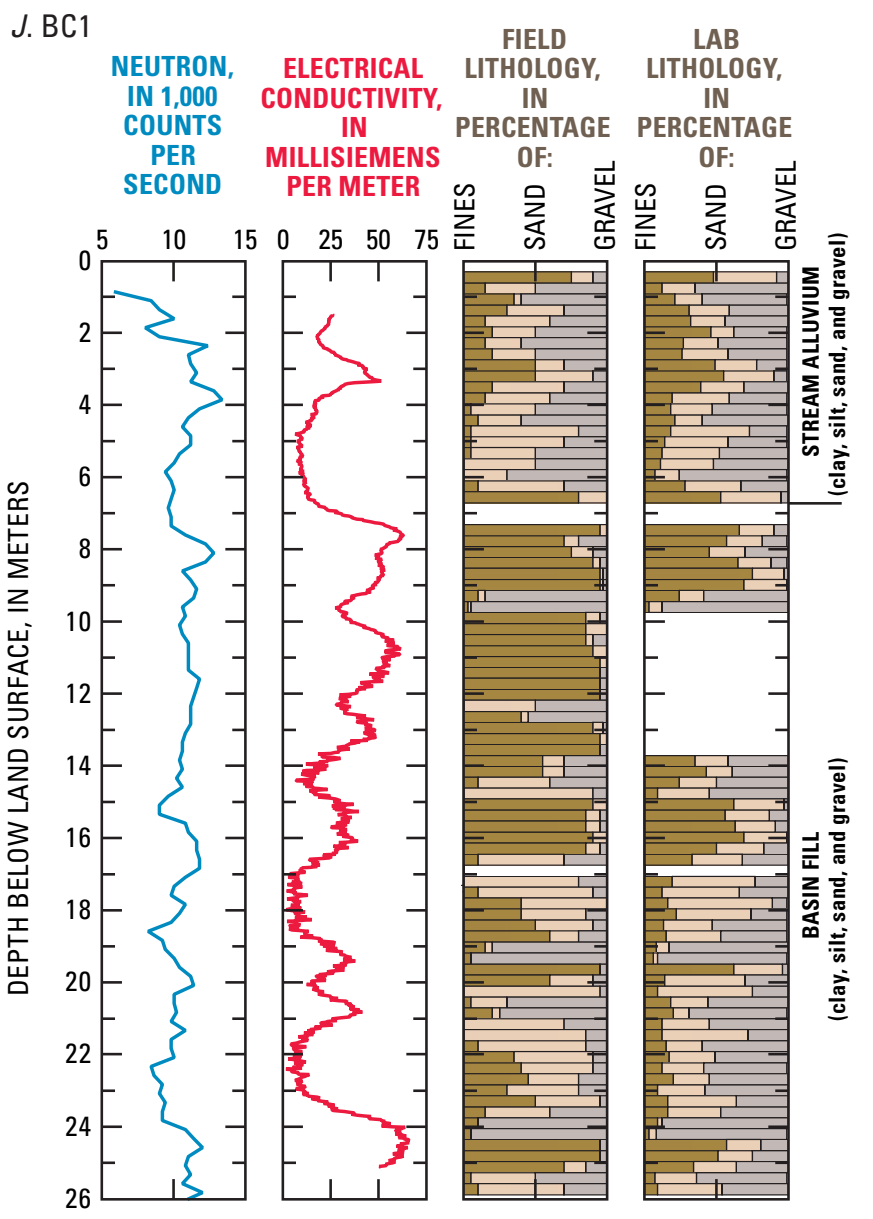

Figure 6. Continued. 


$$
\text { K. GD2 }
$$

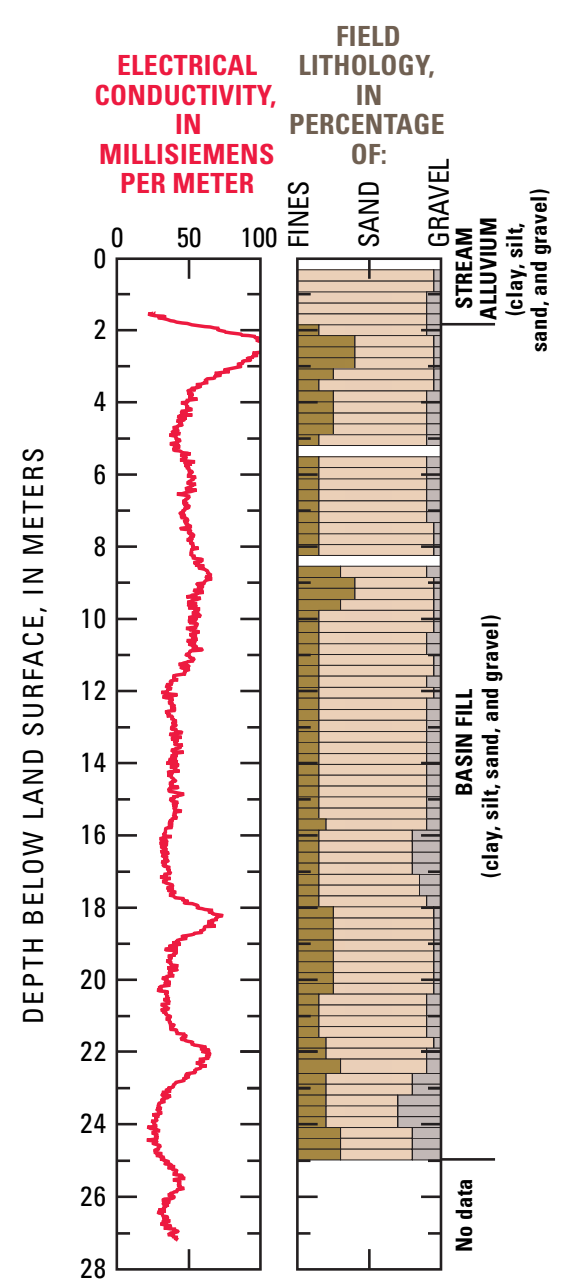

L. GD1

FIELD

IN ELECTRICAL LITHOLOGY IN 1,000 CONDUCTIVITY, COUNTS

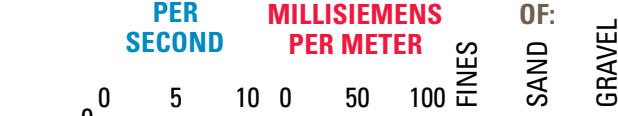
MILLISIEMENS PERCENTAGE

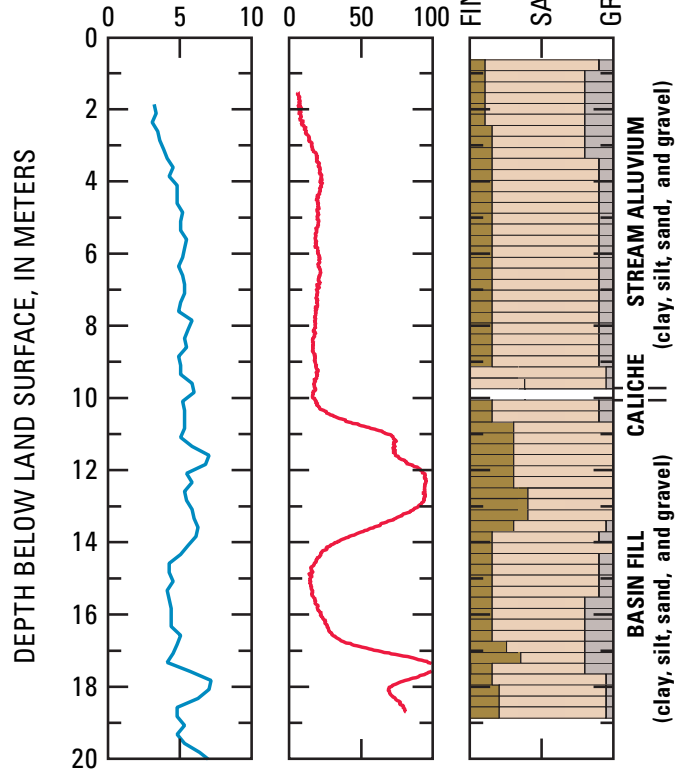

Figure 6. Continued. 
M. WG4

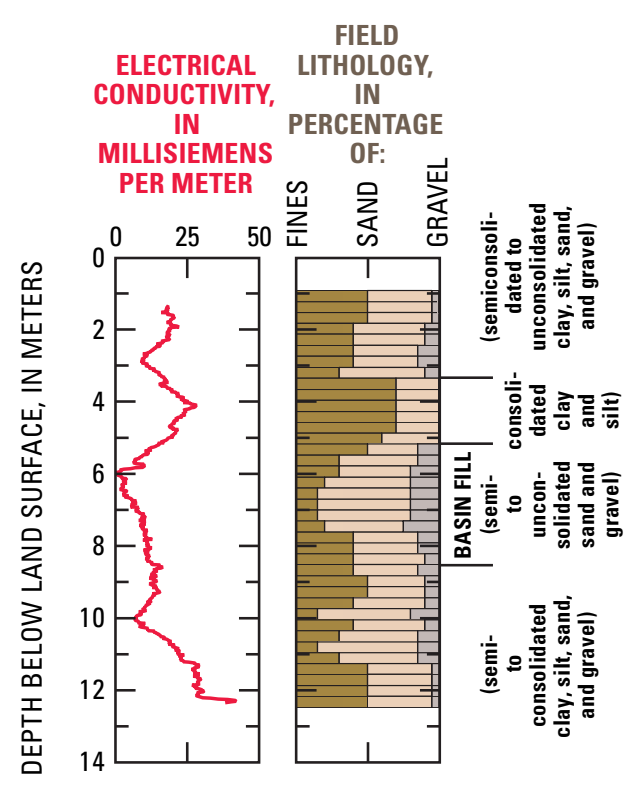

0. BF1

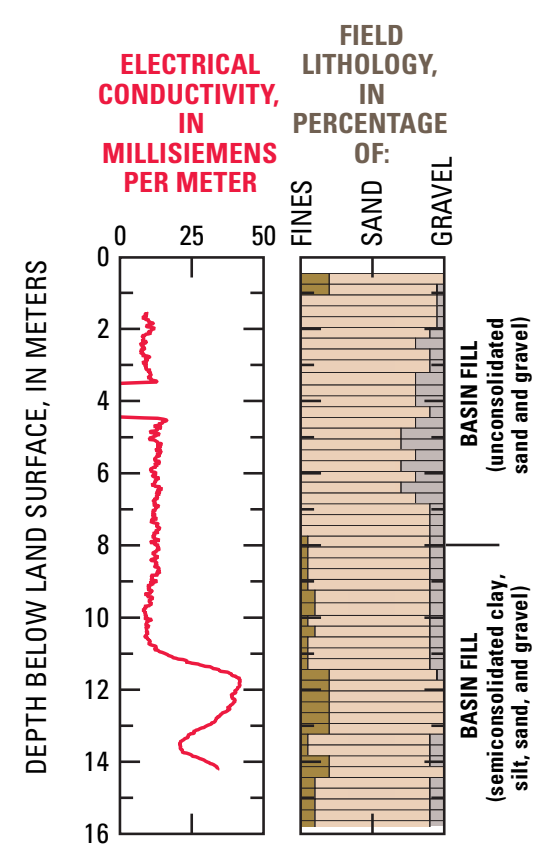

N. WG5

$$
\begin{gathered}
\text { ELECTRICAL } \\
\text { CONDUCTIVITY, } \\
\text { IN } \\
\text { MILLISIEMENS } \\
\text { PER METER }
\end{gathered}
$$

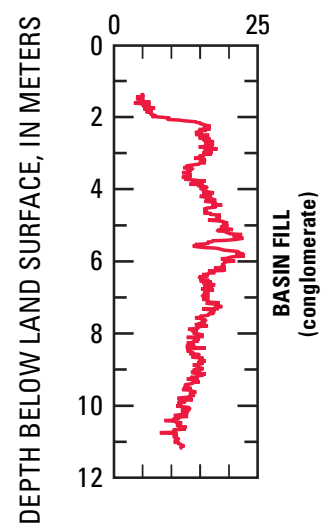

P. WC4c

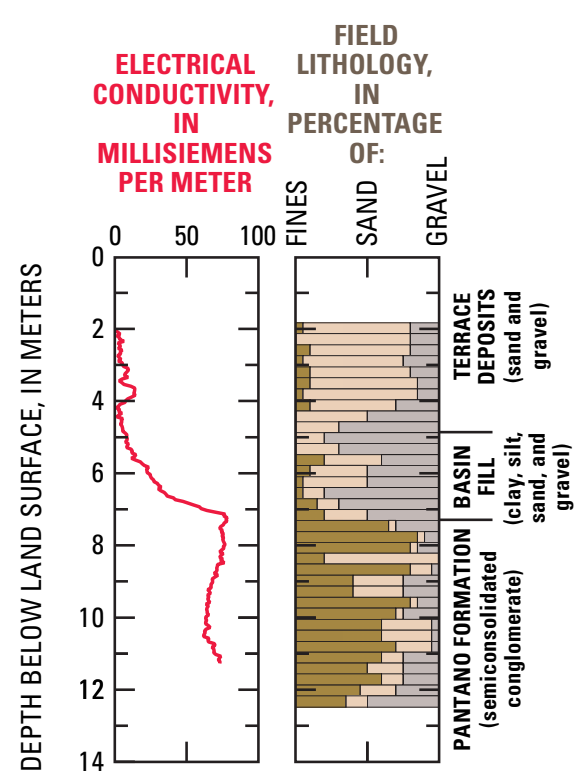

Figure 6. Continued. 
Table 3. Sediment-chloride concentrations of borehole cuttings, Sierra Vista subwatershed, Arizona

[cm, centimeters; m, meters; mg/kg, milligrams chloride per kilograms sediment; ---, no data; <, less than]

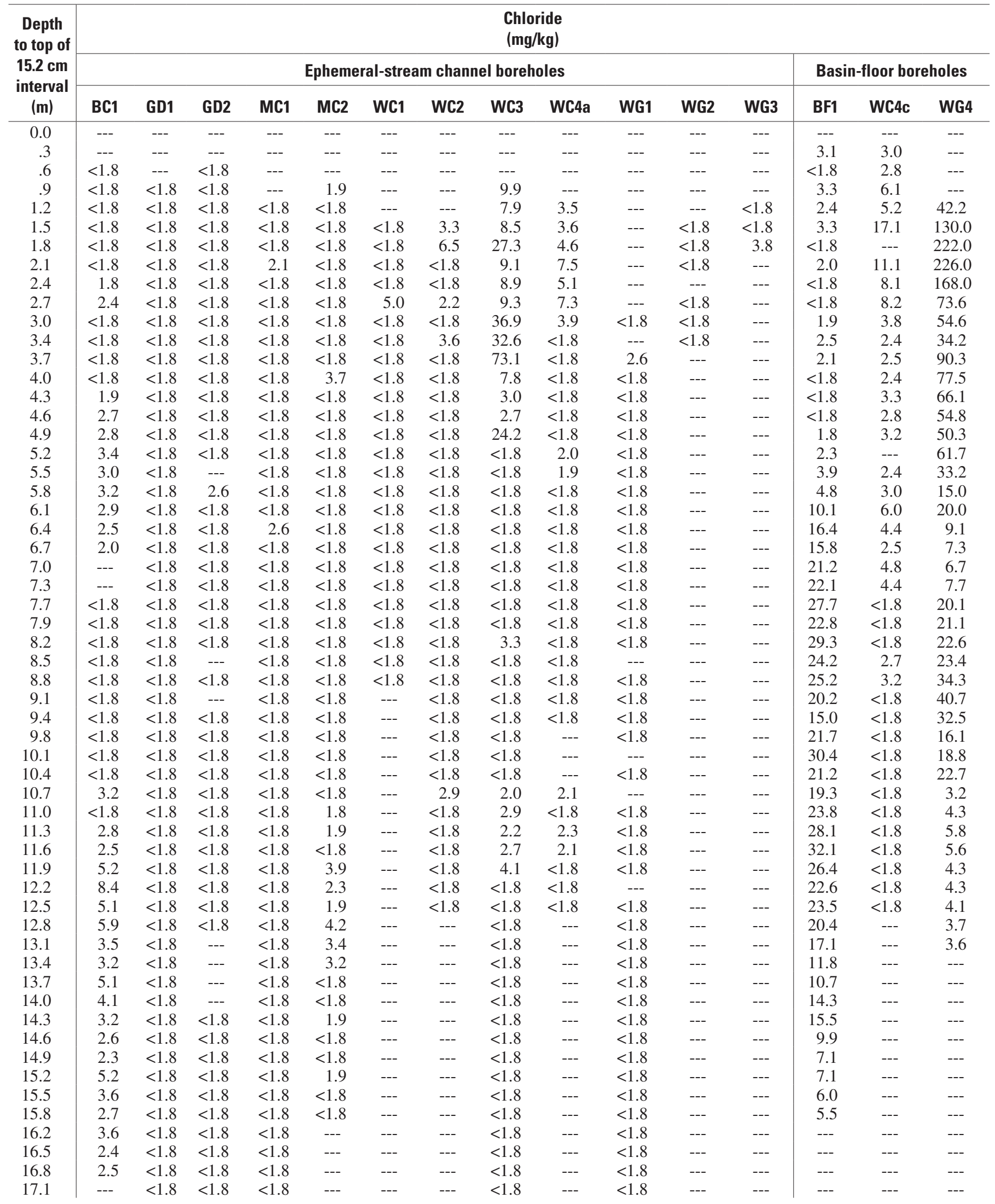


Table 3. Sediment-chloride concentrations of borehole cuttings, Sierra Vista subwatershed, Arizona-Continued

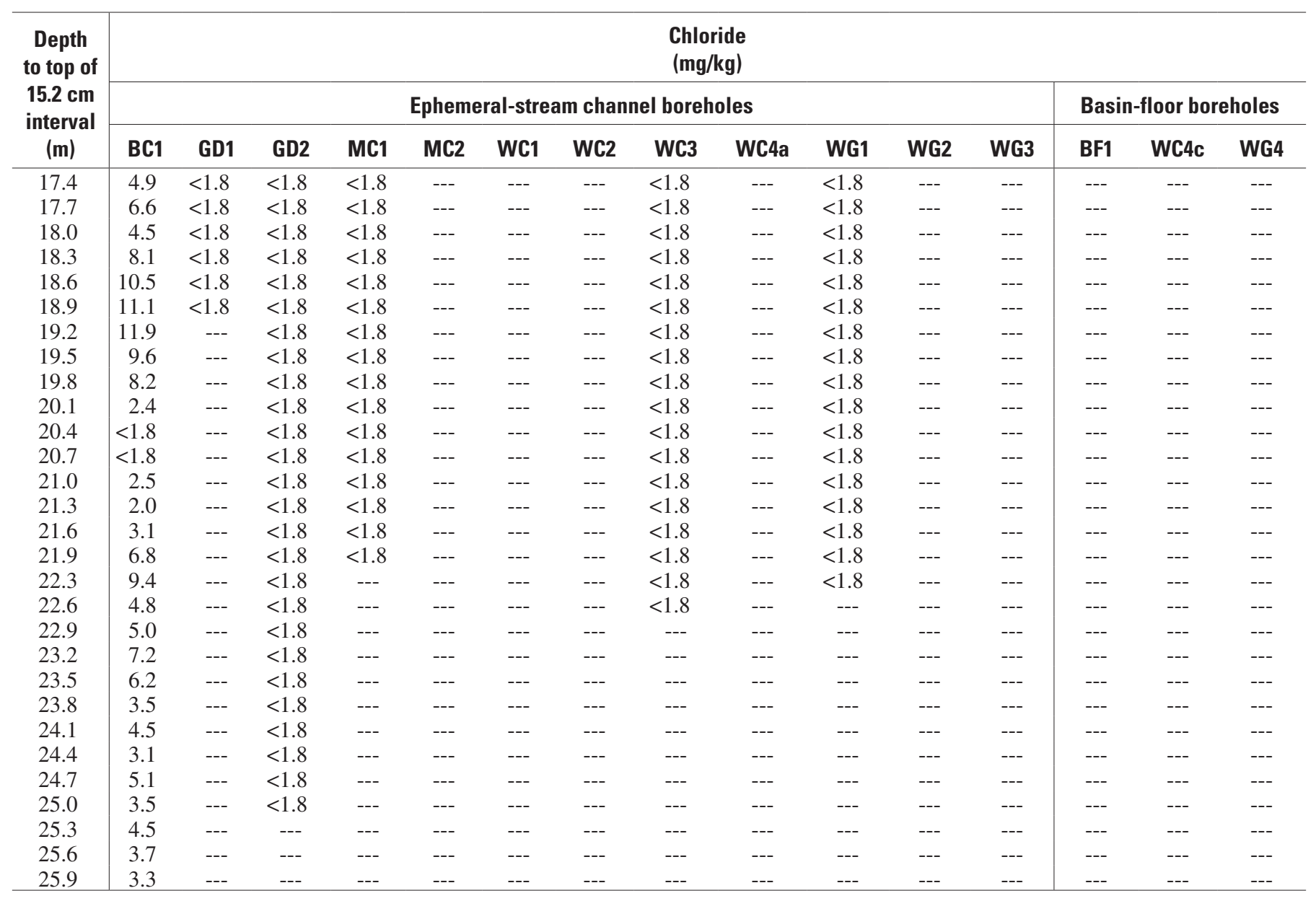


Table 4. Stable-isotope and tritium data for pore water samples from cores, Sierra Vista subwatershed, Arizona [cm, centimeters; m, meters; \%o, per mil; TU, tritium units; ---, no data]

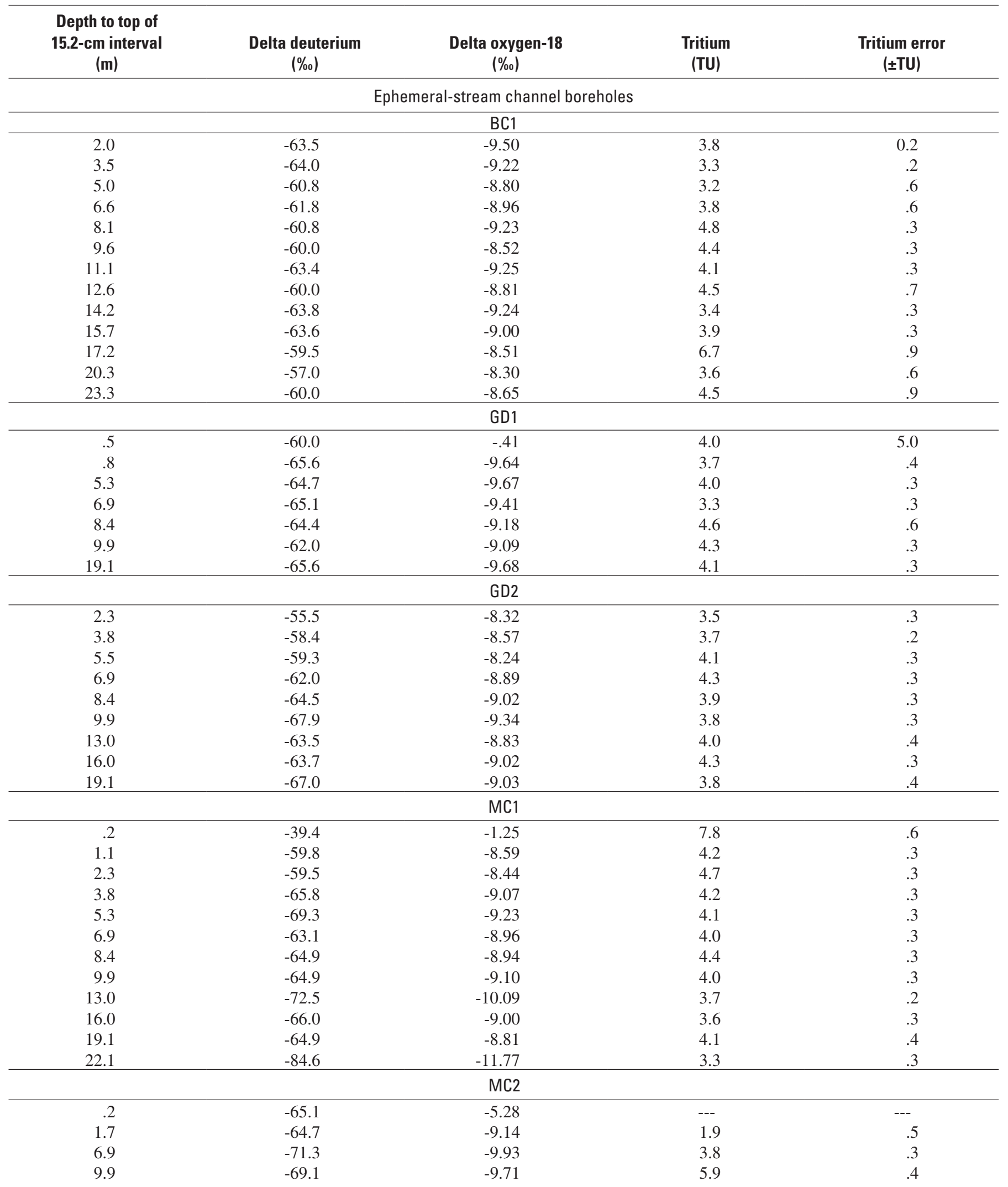


22 Ephemeral-Stream Channel and Basin-Floor Infiltration and Recharge in the Sierra Vista Subwatershed, Arizona

Table 4. Stable-isotope and tritium data for pore water samples from cores, Sierra Vista subwatershed, Arizona—Continued

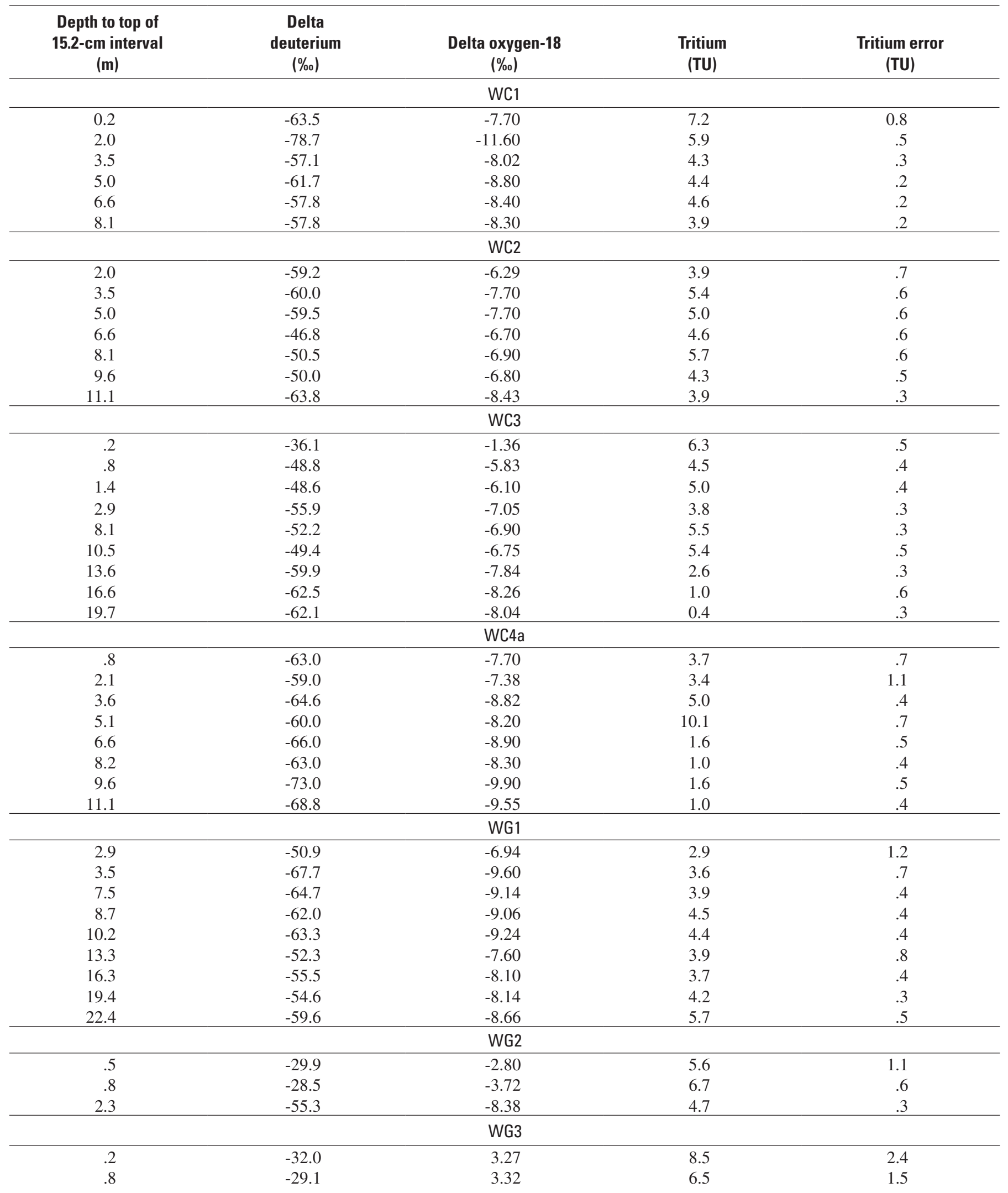


Table 4. Stable-isotope and tritium data for pore water samples from cores, Sierra Vista subwatershed, Arizona—Continued

\begin{tabular}{|c|c|c|c|c|}
\hline $\begin{array}{l}\text { Depth to top of } 15.2-\mathrm{cm} \\
\text { interval } \\
(\mathrm{m})\end{array}$ & $\begin{array}{c}\text { Delta } \\
\text { deuterium } \\
(\%))\end{array}$ & $\begin{array}{c}\text { Delta oxygen-18 } \\
(\%)\end{array}$ & $\begin{array}{l}\text { Tritium } \\
\text { (TU) }\end{array}$ & $\begin{array}{l}\text { Tritium error } \\
\text { (TU) }\end{array}$ \\
\hline \multicolumn{5}{|c|}{ Basin-floor boreholes } \\
\hline \multicolumn{5}{|c|}{ BF1 } \\
\hline 0.5 & -45.8 & -0.60 & 6.4 & 0.9 \\
\hline 3.8 & -62.2 & -7.82 & 6.4 & .9 \\
\hline 5.3 & -59.5 & -7.34 & 2.5 & .6 \\
\hline 6.9 & -57.2 & -7.03 & .8 & .6 \\
\hline 8.4 & -59.8 & -7.11 & .8 & .5 \\
\hline 10.2 & -58.0 & -7.18 & .6 & .4 \\
\hline 13.0 & -56.5 & -7.04 & .3 & .2 \\
\hline \multicolumn{5}{|c|}{ WC4c } \\
\hline .2 & -67.0 & -9.20 & 4.1 & .7 \\
\hline .8 & -75.5 & -10.37 & 2.6 & .8 \\
\hline 1.7 & -68.0 & -9.40 & 4.6 & 1.0 \\
\hline 2.3 & -68.4 & -8.99 & 7.0 & 2.0 \\
\hline 3.7 & -77.0 & -9.60 & 4.9 & 1.4 \\
\hline 5.2 & -64.4 & -8.07 & 3.7 & .4 \\
\hline 6.7 & -59.8 & -7.74 & 5.6 & .3 \\
\hline 8.2 & -63.0 & -8.56 & 11.4 & .4 \\
\hline 9.8 & -63.0 & -8.68 & 10.4 & .4 \\
\hline 11.3 & -71.0 & -9.40 & .3 & .3 \\
\hline \multicolumn{5}{|c|}{ WG4 } \\
\hline .5 & -44.1 & -0.32 & 6.3 & .7 \\
\hline 1.1 & -42.5 & -0.94 & 9.1 & .9 \\
\hline 2.0 & -52.2 & -2.82 & 10.2 & 1.2 \\
\hline 4.1 & -53.8 & -3.91 & 8.2 & .4 \\
\hline 7.5 & -43.1 & -3.37 & 4.0 & 2.4 \\
\hline 13.3 & -55.9 & -5.23 & .4 & .6 \\
\hline \multicolumn{5}{|c|}{ WG5 } \\
\hline .2 & -60.0 & -6.12 & .4 & .4 \\
\hline
\end{tabular}


Table 5. Thermal properties of core material, Sierra Vista subwatershed, Arizona

$\left[\mathrm{cm}\right.$, centimeters; $\mathrm{m}$, meters; $\mathrm{cm}^{3} / \mathrm{cm}^{3}$, cubic centimeter per cubic centimeter; $\mathrm{J} / \mathrm{m}^{3} \cdot{ }^{\circ} \mathrm{C}$, joules per cubic meter degrees Celsius; $\mathrm{J} / \mathrm{s} \cdot \mathrm{m} \cdot{ }^{\circ} \mathrm{C}$, joules per second meter degrees Celsius; ---, no data]

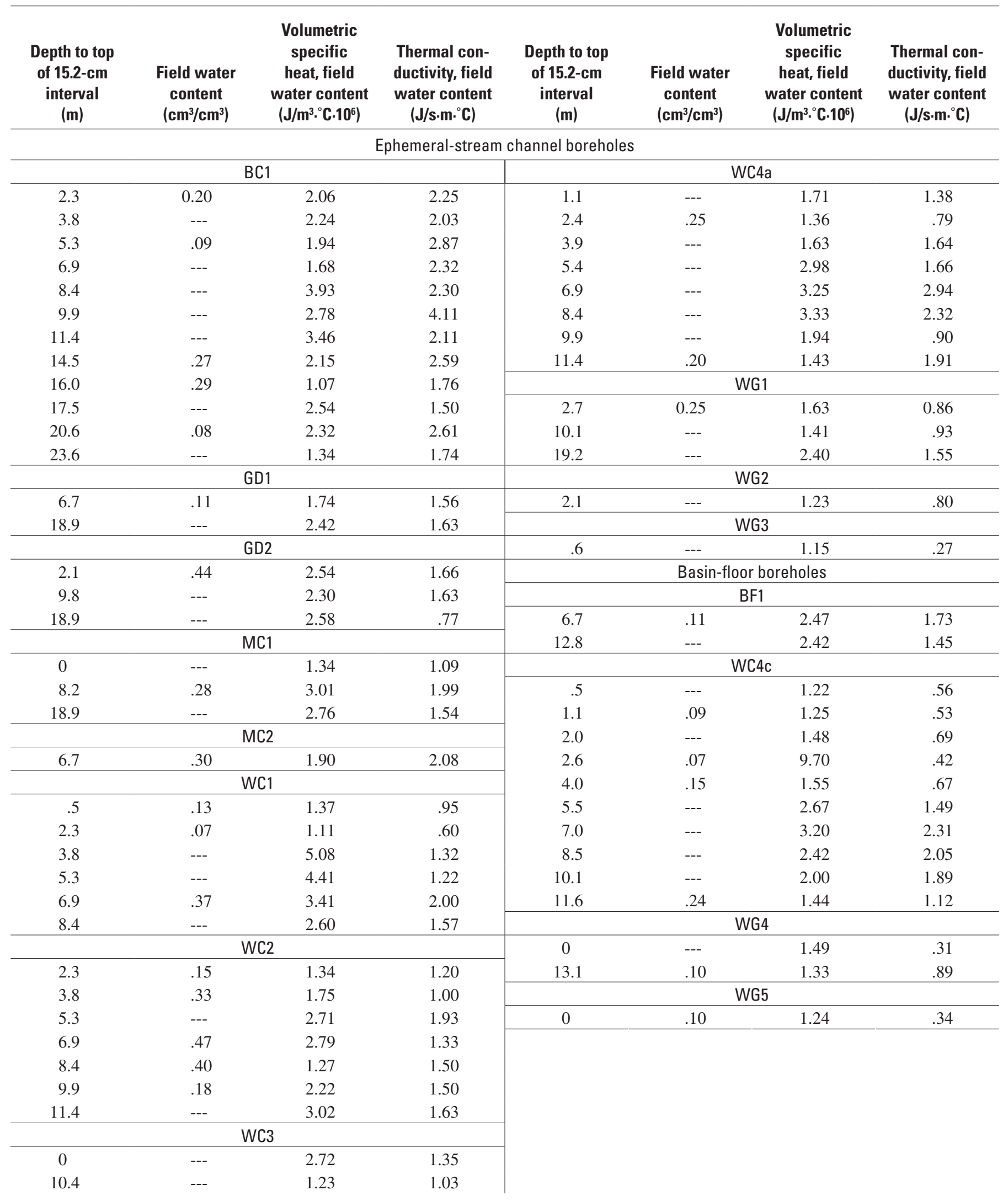


Core analyses for hydraulic properties (saturated hydraulic conductivity and van Genuchten fitting parameters) and physical properties (bulk density, volumetric soil-water content, porosity, and particle density) were completed in a laboratory at the University of Arizona in Tucson (table 6). Initially, each core's weight was measured and its volume calculated. Cores were then fully saturated and weighed again. Saturated hydraulic conductivity $(K$, in L/t) was measured by the falling-head method (Klute and Dirksen, 1986). Reported $K_{s}$ values are the average of two to five falling-head tests run sequentially. Van Genuchten fitting parameters alpha $(\alpha)$, in $1 / \mathrm{L} ; n$, dimensionless; residual soil-water content $\left(\theta_{R}\right)$, in $\mathrm{L}^{3} / \mathrm{L}^{3}$; saturated soil-water content $\left(\theta_{S}\right)$, in $\left.\mathrm{L}^{3} / \mathrm{L}^{3}\right)$ were determined from moisture-release data measured by the pressure-step outflow method (Gardner, 1956) from about 15 to $15,000 \mathrm{~cm}$ water pressure. Cores were then oven dried at $105^{\circ} \mathrm{C}$ for 24 hours, and weighed a third time. Dry bulk density $\left(\rho_{b}\right.$, in $\left.\mathrm{M} / \mathrm{L}^{3}\right)$ was determined by dividing the weight of the core after oven drying by the calculated volume of the core. Gravimetric field soil-water content $\left(\theta_{g}\right.$, in $\left.\mathrm{M} / \mathrm{M}\right)$ was calculated as the difference between the initial core weight and the weight of the core after oven drying, divided by the weight of the core after oven drying. Volumetric field soilwater content $\left(\theta_{v}\right.$, in $\left.\mathrm{L}^{3} / \mathrm{L}^{3}\right)$ was calculated as the product of the gravimetric field soil-water content and the bulk density. Porosity ( $\Phi$, dimensionless) was assumed equal to the saturated soil-water content and was calculated as the product of the bulk density and the difference between the saturated core weight and the dry core weight, divided by the dry core weight. Particle density $\left(\rho_{p}\right.$, in $\left.\mathrm{M} / \mathrm{L}^{3}\right)$ was calculated by:

$$
\rho_{p}=\frac{\rho b}{1-\phi} \text { (Danielson and Sutherland, 1986). (2) }
$$

The Soil, Water, and Plant Analysis Laboratory at the University of Arizona measured particle-size distributions for the cores (table 6). Gravel-size fractions (greater than $2 \mathrm{~mm}$ ) were determined by sieve analysis. Sand-, silt-, and clay-sized fractions were determined by hydrometer analysis (Gee and Bauder, 1986).

\section{Borehole Logging}

Electromagnetic-induction (EMI) and neutron soilmoisture geophysical borehole tools were used to augment subsurface sampling of borehole cuttings and cores (fig. 6). EMI is used to measure the electrical conductivity of the sediments near a borehole by measuring the strength of a secondary magnetic field induced in the sediments by a primary electromagnetic field. The EMI tool has a variable radius of investigation dependent on the frequency of the primary field, the spacing between the primary and secondary magnetic coils, and the subsurface conductivity. A frequency of about 40 kilohertz and a coil spacing of $0.5 \mathrm{~m}$ was used for this investigation. At this EMI setting, about 90 percent of the secondary magnetic field results from materials within a radius of about $1.3 \mathrm{~m}$ from the center of the coil spacing (Peterson, 1999). Variations in subsurface electrical conductivity are primarily caused by variations in amounts of electrically conductive silt, clay, and dissolved ions in water. Electrical conductivity is proportional to silt, clay, and soilwater contents. Dry zones with little silt and clay can have electrical conductivity values well below 10 millisiemens per meter $(\mathrm{mS} / \mathrm{m})$, but saturated clay can have values greater than $100 \mathrm{mS} / \mathrm{m}$. Variations in electrical conductivity can also be related to variations in electrically conductive salts; however, the salt contents in most of the boreholes drilled for this investigation were very low and did not likely contribute significantly to variations in electrical conductivity.

The neutron tool used in this study contained a 50-millicurie americium-241/beryllium neutron source and detector to measure variations in the amount of water molecules near the borehole. The tool had a radius of investigation of about 60 to $75 \mathrm{~cm}$. Response of the neutron tool is reported as measured neutron counts at the detector; higher neutron counts indicate greater amounts of water near the borehole. Neutron counts can be converted to soil-water content by using a soil-dependent calibration; however, calibration was not attempted for this investigation, and the resultant neutron counts from different boreholes can only be compared in a relative sense.

\section{Borehole Monitoring}

Onset StowAway TidbiT temperature sensors were installed in boreholes $\mathrm{WC} 1, \mathrm{WC} 4 \mathrm{a}, \mathrm{WC} 4 \mathrm{c}$, and $\mathrm{BC} 1$ in February 2001, and in boreholes WC3, MC1, MC2, BF1, GD1, GD2, WG1, and WG2 from January to May 2002. Sensors were installed from land surface to a maximum depth of $12.2 \mathrm{~m}$ at intervals of 1.5 to $3.0 \mathrm{~m}$ (table 2). Additionally, at most boreholes, a sensor was buried about $15 \mathrm{~cm}$ below land surface next to the borehole surface casing. Temperature was measured and recorded every 30 minutes. The TidbiT sensors measure temperatures of $-5^{\circ} \mathrm{C}$ to $+37^{\circ} \mathrm{C}$ with an accuracy of $\pm 0.2^{\circ} \mathrm{C}$.

In-Situ Inc. miniTROLL pressure transducers were installed in the three boreholes that intercepted saturated intervals (WC1, WC4a, and WC4c) during February 2001. Depth to water was measured and recorded every 30 minutes.

\section{Precipitation Collection and Analysis}

Composite atmospheric deposition samples were collected twice a year after the summer (April to October) and winter (October to April) rains at the Upper Babocomari River and Greenbush Draw streamflow-gaging stations (fig. 1). Sample collection began in July 2000 and continued through April 2003. Samples were analyzed for bulk chloride concentrations, stable-isotope values, and tritium activity (table 7). Bulk chloride was determined by ion chromatography at the USGS laboratory in San Diego, California. The stable isotopes of oxygen and hydrogen were analyzed at the USGS Isotope Fractionation Project Laboratory in Reston, Virginia. Tritium activity was determined at the Laboratory of Isotope Geochemistry at the University of Arizona in Tucson. 
[cm, centimeters; $\mathrm{m}$, meters; $\%$, percent; $\mathrm{g} / \mathrm{cm}^{3}$, grams per cubic centimeter; $\mathrm{cm}^{3} / \mathrm{cm}^{3}$, cubic centimeter per cubic centimeter; $\mathrm{cm} / \mathrm{s}$, centimeters per second; $1 / \mathrm{cm}$, inverse centimeters; ---, no data. Cores of basin fill material could not be collected at WGZ and WG3, and properties were not determined for the stream alluvium at these boreholes]

\begin{tabular}{|c|c|c|c|c|c|c|c|c|c|c|c|c|c|c|c|}
\hline \multirow[b]{2}{*}{$\begin{array}{l}\text { Depth } \\
\text { to top of } \\
7.6-\mathrm{cm} \\
\text { interval } \\
\text { (m) }\end{array}$} & \multirow[b]{2}{*}{$\begin{array}{c}\text { Gravel } \\
(\%)\end{array}$} & \multirow[b]{2}{*}{$\begin{array}{c}\text { Sand } \\
(\%)\end{array}$} & \multirow[b]{2}{*}{$\begin{array}{l}\text { Silt } \\
(\%)\end{array}$} & \multirow[b]{2}{*}{$\begin{array}{l}\text { Clay } \\
(\%)\end{array}$} & \multirow[b]{2}{*}{$\begin{array}{c}\text { Bulk } \\
\text { density } \\
\left(\mathrm{g} / \mathrm{cm}^{3}\right)\end{array}$} & \multirow[b]{2}{*}{$\begin{array}{l}\text { Particle } \\
\text { density } \\
\left(\mathrm{g} / \mathrm{cm}^{3}\right)\end{array}$} & \multirow[b]{2}{*}{$\begin{array}{l}\text { Porosity } \\
\left(\mathrm{cm}^{3} / \mathrm{cm}^{3}\right)\end{array}$} & \multirow[b]{2}{*}{$\begin{array}{c}\text { Volumetric } \\
\text { water content, } \\
\text { field } \\
\left(\mathrm{cm}^{3} / \mathrm{cm}^{3}\right)\end{array}$} & \multirow[b]{2}{*}{$\begin{array}{c}\text { Saturated } \\
\text { hydraulic } \\
\text { conductivity } \\
\text { (cm/s) }\end{array}$} & \multicolumn{6}{|c|}{ van Genuchten fitting parameters } \\
\hline & & & & & & & & & & $\begin{array}{c}\alpha \\
(1 / \mathrm{cm})\end{array}$ & $\begin{array}{c}\text { n } \\
\text { (dimen- } \\
\text { sionless) }\end{array}$ & $\underset{(1-1 / n)}{m}$ & $\begin{array}{c}\text { Residual } \\
\text { water } \\
\text { content } \\
\left(\mathrm{cm}^{3} / \mathrm{cm}^{3}\right)\end{array}$ & $\begin{array}{c}\text { Saturated } \\
\text { water } \\
\text { content } \\
\left(\mathrm{cm}^{3} / \mathrm{cm}^{3}\right)\end{array}$ & $\mathbf{R}^{2}$ \\
\hline \multicolumn{16}{|c|}{ Ephemeral-stream channel boreholes } \\
\hline \multicolumn{16}{|c|}{$\mathrm{BC} 1$} \\
\hline 2.1 & 63.7 & 22.6 & 8.9 & 4.8 & 1.85 & 2.81 & 0.34 & 0.20 & $9.6 \cdot 10^{-3}$ & 0.145 & 1.86 & 0.46 & 0.19 & 0.34 & 0.99 \\
\hline 5.2 & 79.7 & 16.2 & 2.6 & 1.5 & 1.82 & 2.65 & .31 & .09 & $1.2 \cdot 10^{-1}$ & .122 & 2.01 & .50 & .11 & .31 & 1.00 \\
\hline 8.2 & --- & --- & --- & --- & --- & --- & --- & --- & $4.1 \cdot 10^{-7}$ & --- & --- & --- & --- & --- & --- \\
\hline 14.3 & 70.8 & 19.9 & 7.4 & 1.9 & 1.82 & 3.00 & .39 & .27 & $1.7 \cdot 10^{-6}$ & .138 & 1.45 & .31 & .07 & .39 & 1.00 \\
\hline 15.8 & 35.3 & 37.8 & 23.5 & 3.4 & 1.63 & 2.88 & .43 & .29 & $3.3 \cdot 10^{-5}$ & .009 & 1.62 & .38 & .16 & .42 & 1.00 \\
\hline 20.4 & 77.7 & 19.5 & 1.9 & .9 & 2.02 & 2.70 & .25 & .08 & $8.9 \cdot 10^{-3}$ & .145 & 1.96 & .49 & .08 & .25 & 1.00 \\
\hline \multicolumn{16}{|c|}{ GD1 } \\
\hline 4.0 & 47.6 & 48.3 & 2.2 & 1.9 & 1.82 & 2.49 & .27 & .15 & $1.4 \cdot 10^{-2}$ & .145 & 2.19 & .54 & .11 & .26 & .95 \\
\hline 7.0 & 46.1 & 47.6 & 2.8 & 3.5 & 1.89 & --- & --- & .11 & $4.6 \cdot 10^{-3}$ & .145 & 1.29 & .23 & .06 & .36 & 1.00 \\
\hline 13.1 & 19.4 & 38.9 & 27.3 & 14.4 & --- & -- & --- & -- & $6.8 \cdot 10^{-8}$ & -- & -- & --- & -- & --- & --- \\
\hline \multicolumn{16}{|c|}{ GD2 } \\
\hline 2.4 & 2.7 & 66.1 & 21.9 & 9.3 & 1.47 & 3.11 & .53 & .44 & $5.9 \cdot 10^{-3}$ & .067 & 1.11 & .10 & .20 & .50 & .99 \\
\hline 5.3 & 50.7 & 33.0 & 4.2 & 12.1 & 1.44 & 2.60 & .45 & .14 & $5.3 \cdot 10^{-2}$ & .145 & 2.54 & .61 & .18 & .44 & .97 \\
\hline 13.1 & 70.9 & 12.5 & 4.2 & 12.4 & 1.57 & 2.64 & .41 & .27 & $1.6 \cdot 10^{-2}$ & .145 & 2.40 & .58 & .25 & .40 & .97 \\
\hline \multicolumn{16}{|c|}{ MC1 } \\
\hline 0.9 & 4.2 & 60.1 & 22.9 & 12.8 & 1.84 & 2.87 & .36 & --- & $9.3 \cdot 10^{-3}$ & .145 & 1.20 & .17 & .11 & .36 & .99 \\
\hline 4.0 & 18.9 & 44.6 & 19.1 & 17.4 & 1.84 & 2.91 & .37 & .31 & $3.5 \cdot 10^{-6}$ & .005 & 1.33 & .25 & .12 & .35 & .95 \\
\hline 8.5 & 4.2 & 57.6 & 25.3 & 12.9 & 1.78 & 2.92 & .39 & .28 & $1.3 \cdot 10^{-3}$ & .005 & 1.21 & .17 & .12 & .39 & .95 \\
\hline 19.2 & 4.5 & 31.5 & 32.1 & 31.9 & --- & --- & --- & --- & $1.8 \cdot 10^{-6}$ & --- & --- & --- & --- & --- & --- \\
\hline \multicolumn{16}{|c|}{ MC2 } \\
\hline 1.8 & 36.4 & 42.7 & 12.2 & 8.7 & 1.37 & 2.35 & .42 & .18 & $3.3 \cdot 10^{-3}$ & .066 & 1.22 & .19 & .08 & .41 & .99 \\
\hline 7.0 & 3.7 & 63.7 & 21.0 & 11.6 & 1.87 & 2.92 & .36 & .30 & $3.2 \cdot 10^{-6}$ & .013 & 1.37 & .27 & .16 & .36 & .95 \\
\hline 10.1 & 73.0 & 19.0 & 4.9 & 3.1 & 1.60 & 2.76 & .42 & .22 & $1.7 \cdot 10^{-2}$ & .136 & 1.33 & .25 & .14 & .42 & .97 \\
\hline
\end{tabular}


Table 6. Physical and hydraulic properties of core material, Sierra Vista subwatershed, Arizona-Continued

\begin{tabular}{|c|c|c|c|c|c|c|c|c|c|c|c|c|c|c|c|}
\hline \multirow[b]{2}{*}{$\begin{array}{l}\text { Depth } \\
\text { to top of } \\
7.6-\mathrm{cm} \\
\text { interval } \\
\text { (m) }\end{array}$} & \multirow[b]{2}{*}{$\begin{array}{c}\text { Gravel } \\
(\%)\end{array}$} & \multirow[b]{2}{*}{$\begin{array}{c}\text { Sand } \\
(\%)\end{array}$} & \multirow[b]{2}{*}{$\begin{array}{l}\text { Silt } \\
(\%)\end{array}$} & \multirow[b]{2}{*}{$\begin{array}{l}\text { Clay } \\
(\%)\end{array}$} & \multirow[b]{2}{*}{$\begin{array}{c}\text { Bulk } \\
\text { density } \\
\left(\mathrm{g} / \mathrm{cm}^{3}\right)\end{array}$} & \multirow[b]{2}{*}{$\begin{array}{l}\text { Particle } \\
\text { density } \\
\left(\mathrm{g} / \mathrm{cm}^{3}\right)\end{array}$} & \multirow[b]{2}{*}{$\begin{array}{l}\text { Porosity } \\
\left(\mathrm{cm}^{3} / \mathrm{cm}^{3}\right)\end{array}$} & \multirow[b]{2}{*}{$\begin{array}{c}\text { Volumetric } \\
\text { water content, } \\
\text { field } \\
\left(\mathrm{cm}^{3} / \mathrm{cm}^{3}\right)\end{array}$} & \multirow[b]{2}{*}{$\begin{array}{c}\text { Saturated } \\
\text { hydraulic } \\
\text { conductivity } \\
(\mathrm{cm} / \mathrm{s})\end{array}$} & \multicolumn{6}{|c|}{ van Genuchten fitting parameters } \\
\hline & & & & & & & & & & $\begin{array}{c}\alpha \\
(1 / \mathrm{cm})\end{array}$ & $\begin{array}{c}\text { n } \\
\text { (dimen- } \\
\text { sionless) }\end{array}$ & $\underset{(1-1 / n)}{m}$ & $\begin{array}{c}\text { Residual } \\
\text { water } \\
\text { content } \\
\left(\mathrm{cm}^{3} / \mathrm{cm}^{3}\right)\end{array}$ & $\begin{array}{c}\text { Saturated } \\
\text { water } \\
\text { content } \\
\left(\mathrm{cm}^{3} / \mathrm{cm}^{3}\right)\end{array}$ & $\mathbf{R}^{2}$ \\
\hline \multicolumn{16}{|c|}{ Ephemeral-stream channel boreholes } \\
\hline \multicolumn{16}{|c|}{ WC1 } \\
\hline 0.3 & 25.6 & 72.5 & $<0.7$ & 1.9 & 1.49 & 2.74 & 0.46 & 0.13 & $7.2 \cdot 10^{-2}$ & 0.145 & 2.44 & 0.59 & 0.05 & 0.45 & 0.98 \\
\hline 2.1 & 53.0 & 43.5 & 1.0 & 2.5 & 1.84 & 2.90 & .37 & .07 & $3.6 \cdot 10^{-2}$ & .145 & 2.32 & .57 & .07 & .36 & .97 \\
\hline 3.7 & 45.1 & 36.1 & 13.0 & 5.8 & --- & --- & --- & --- & $3.2 \cdot 10^{-3}$ & .006 & 1.23 & .19 & .28 & .54 & 1.00 \\
\hline 6.7 & 61.1 & 20.8 & 12.1 & 6.0 & 1.69 & --- & --- & .37 & $2.1 \cdot 10^{-6}$ & .008 & 1.59 & .37 & .22 & .52 & .98 \\
\hline \multicolumn{16}{|c|}{ WC2 } \\
\hline 2.1 & 34.7 & 61.8 & .2 & 3.3 & 1.71 & 2.64 & .35 & .15 & $6.3 \cdot 10^{-3}$ & .145 & 2.56 & .61 & .07 & .35 & .97 \\
\hline 3.7 & 22.0 & 39.5 & 22.7 & 15.8 & 1.64 & 3.18 & .48 & .33 & $2.2 \cdot 10^{-2}$ & .106 & 1.25 & .20 & .22 & .48 & .96 \\
\hline 6.7 & 59.0 & 14.5 & 12.7 & 13.8 & 1.43 & 2.95 & .52 & .47 & $5.0 \cdot 10^{-4}$ & .028 & 1.15 & .13 & .20 & .52 & .95 \\
\hline 8.2 & 27.4 & 30.1 & 30.7 & 11.8 & 1.52 & 2.92 & .48 & .40 & $9.8 \cdot 10^{-6}$ & .014 & 1.41 & .29 & .21 & .47 & .95 \\
\hline 9.8 & 15.9 & 76.1 & 3.7 & 4.3 & 1.65 & 2.48 & .34 & .18 & $3.0 \cdot 10^{-3}$ & .068 & 1.51 & .34 & .10 & .32 & .97 \\
\hline \multicolumn{16}{|c|}{ WC3 } \\
\hline 0.9 & 38.7 & 45.3 & 4.8 & 11.2 & 1.64 & 2.48 & .34 & .11 & $8.5 \cdot 10^{-3}$ & .145 & 2.03 & .51 & .13 & .34 & 1.00 \\
\hline 1.5 & --- & --- & --- & --- & --- & --- & --- & --- & $1.7 \cdot 10^{-4}$ & --- & --- & --- & --- & --- & --- \\
\hline 8.2 & 92.4 & 5.0 & 1.7 & .9 & 1.75 & 2.60 & .33 & .21 & $2.3 \cdot 10^{-3}$ & .043 & 1.36 & .27 & .08 & .32 & .97 \\
\hline 13.7 & 20.7 & 62.4 & 9.8 & 7.1 & 1.64 & 2.71 & .39 & .11 & $9.9 \cdot 10^{-3}$ & .162 & 1.53 & .35 & .10 & .39 & 1.00 \\
\hline 19.8 & 11.3 & 58.9 & 22.6 & 7.2 & 1.72 & 2.88 & .40 & .19 & $5.8 \cdot 10^{-3}$ & .068 & 1.37 & .27 & .13 & .39 & .98 \\
\hline \multicolumn{16}{|c|}{ WC4a } \\
\hline 2.1 & 78.7 & 15.9 & 1.9 & 3.5 & 1.81 & 3.16 & .43 & .25 & $6.4 \cdot 10^{-2}$ & .145 & 2.03 & .51 & .15 & .42 & .99 \\
\hline 11.3 & 48.5 & 32.7 & 11.7 & 7.1 & 1.80 & 2.69 & .33 & .20 & $4.2 \cdot 10^{-4}$ & .049 & 1.48 & .32 & .22 & .33 & 1.00 \\
\hline \multicolumn{16}{|c|}{ WG1 } \\
\hline 3.0 & 68.5 & 27.9 & 1.4 & 2.2 & 1.68 & 2.97 & .43 & .25 & $2.0 \cdot 10^{-2}$ & .146 & 1.39 & .28 & .05 & .43 & 1.00 \\
\hline 3.7 & 72.8 & 24.0 & 1.6 & 1.6 & 1.84 & 2.81 & .35 & .13 & $4.6 \cdot 10^{-2}$ & .145 & 1.51 & .34 & .04 & .34 & .98 \\
\hline 13.4 & 43.9 & 52.9 & .7 & 2.5 & 1.37 & 2.58 & .47 & .10 & $4.0 \cdot 10^{-2}$ & .145 & 1.98 & .50 & .07 & .47 & .99 \\
\hline 22.6 & 66.0 & 27.8 & 5.7 & .5 & 1.59 & 2.66 & .40 & .19 & $2.0 \cdot 10^{-2}$ & .145 & 1.29 & .23 & .05 & .39 & .97 \\
\hline
\end{tabular}




\begin{tabular}{|c|c|c|c|c|c|c|c|c|c|c|c|c|c|c|c|}
\hline \multirow[b]{2}{*}{$\begin{array}{l}\text { Depth } \\
\text { to top of } \\
7.6-\mathrm{cm} \\
\text { interval } \\
\text { (m) }\end{array}$} & \multirow[b]{2}{*}{$\begin{array}{c}\text { Gravel } \\
(\%)\end{array}$} & \multirow[b]{2}{*}{$\begin{array}{c}\text { Sand } \\
(\%)\end{array}$} & \multirow[b]{2}{*}{$\begin{array}{l}\text { Silt } \\
(\%)\end{array}$} & \multirow[b]{2}{*}{$\begin{array}{l}\text { Clay } \\
(\%)\end{array}$} & \multirow[b]{2}{*}{$\begin{array}{c}\text { Bulk } \\
\text { density } \\
\left(\mathrm{g} / \mathrm{cm}^{3}\right)\end{array}$} & \multirow[b]{2}{*}{$\begin{array}{l}\text { Particle } \\
\text { density } \\
\left(\mathrm{g} / \mathrm{cm}^{3}\right)\end{array}$} & \multirow[b]{2}{*}{$\begin{array}{c}\text { Porosity } \\
\left(\mathrm{cm}^{3} / \mathrm{cm}^{3}\right)\end{array}$} & \multirow[b]{2}{*}{$\begin{array}{c}\text { Volumetric } \\
\text { water content, } \\
\text { field } \\
\left(\mathrm{cm}^{3} / \mathrm{cm}^{3}\right)\end{array}$} & \multirow[b]{2}{*}{$\begin{array}{c}\text { Saturated } \\
\text { hydraulic } \\
\text { conductivity } \\
(\mathrm{cm} / \mathrm{s})\end{array}$} & \multicolumn{6}{|c|}{ van Genuchten fitting parameters } \\
\hline & & & & & & & & & & $\begin{array}{c}\alpha \\
(1 / \mathrm{cm})\end{array}$ & $\begin{array}{c}n \\
\text { (dimen- } \\
\text { sionless) }\end{array}$ & $\underset{(1-1 / n)}{m}$ & $\begin{array}{c}\text { Residual } \\
\text { water } \\
\text { content } \\
\left(\mathrm{cm}^{3} / \mathrm{cm}^{3}\right)\end{array}$ & $\begin{array}{c}\text { Saturated } \\
\text { water } \\
\text { content } \\
\left(\mathrm{cm}^{3} / \mathrm{cm}^{3}\right)\end{array}$ & $\mathbf{R}^{2}$ \\
\hline \multicolumn{16}{|c|}{ Basin-floor boreholes } \\
\hline \multicolumn{16}{|c|}{ BF1 } \\
\hline 0.3 & 41.7 & 43.3 & 7.0 & 8.0 & 1.52 & 2.51 & 0.39 & $<0.02$ & $2.1 \cdot 10^{-2}$ & 0.076 & 2.11 & 0.53 & 0.09 & 0.40 & 1.00 \\
\hline 4.0 & 68.0 & 25.8 & 2.5 & 3.7 & --- & --- & --- & --- & --- & --- & --- & --- & --- & --- & --- \\
\hline 5.5 & 76.5 & 16.5 & 1.7 & 5.3 & --- & --- & --- & --- & --- & --- & --- & --- & --- & --- & --- \\
\hline 7.0 & 64.1 & 28.5 & 3.1 & 4.3 & 1.77 & 2.72 & .35 & .11 & $1.4 \cdot 10^{-2}$ & .137 & 1.72 & .42 & .14 & .35 & .99 \\
\hline 8.5 & 34.8 & 34.5 & 21.0 & 9.7 & 1.60 & 2.92 & .45 & .26 & $5.1 \cdot 10^{-3}$ & .073 & 1.28 & .22 & .18 & .46 & .95 \\
\hline 10.1 & 77.0 & 18.5 & 2.4 & 2.1 & --- & --- & --- & --- & --- & --- & --- & --- & --- & --- & --- \\
\hline 13.1 & 60.7 & 24.6 & 7.7 & 7.0 & --- & --- & --- & --- & --- & --- & --- & --- & --- & --- & --- \\
\hline \multicolumn{16}{|c|}{ WC4c } \\
\hline 1.1 & 41.1 & 54.4 & 1.0 & 3.5 & 1.70 & 2.54 & .33 & .09 & $1.5 \cdot 10^{-2}$ & .166 & 1.58 & .37 & .03 & .33 & .98 \\
\hline 2.4 & 51.6 & 43.9 & 1.7 & 2.8 & 1.69 & 2.57 & .34 & .07 & $5.1 \cdot 10^{-3}$ & .145 & 1.81 & .45 & .05 & .34 & .99 \\
\hline 3.8 & 23.9 & 68.5 & 2.1 & 5.5 & 1.66 & 2.76 & .40 & .15 & $1.5 \cdot 10^{-3}$ & .071 & 1.89 & .47 & .06 & .40 & 1.00 \\
\hline 9.9 & 68.3 & 19.1 & 9.3 & 3.3 & --- & --- & --- & --- & $1.9 \cdot 10^{-5}$ & .025 & 3.89 & .74 & .27 & .40 & .99 \\
\hline 11.3 & 56.6 & 31.0 & 9.6 & 2.8 & 1.83 & 2.87 & .36 & .24 & $7.2 \cdot 10^{-6}$ & .021 & 2.09 & .52 & .27 & .36 & .97 \\
\hline \multicolumn{16}{|c|}{ WG4 } \\
\hline 4.3 & 47.6 & 26.0 & 17.2 & 9.2 & 1.24 & 2.38 & .48 & .19 & $1.3 \cdot 10^{-2}$ & .122 & 1.21 & .17 & .15 & .48 & 1.00 \\
\hline 13.4 & 36.3 & 37.2 & 18.6 & 7.9 & 1.30 & 2.61 & .50 & .10 & $1.7 \cdot 10^{-2}$ & .077 & 1.63 & .39 & .17 & .47 & .96 \\
\hline \multicolumn{16}{|c|}{ WG5 } \\
\hline .3 & 34.0 & 47.2 & 15.6 & 3.2 & 1.41 & 2.71 & .48 & .10 & $1.5 \cdot 10^{-2}$ & .126 & 1.40 & .29 & .10 & .48 & .98 \\
\hline
\end{tabular}


Table 7. Isotope and chloride data for composite precipitation samples, July 2000-April 2003, Sierra Vista subwatershed, Arizona

[cm, centimeters; mg/ $\mathrm{cm}^{2}$, milligrams per square centimeter; \%o, per mil; TU, tritium units; ---, no data]

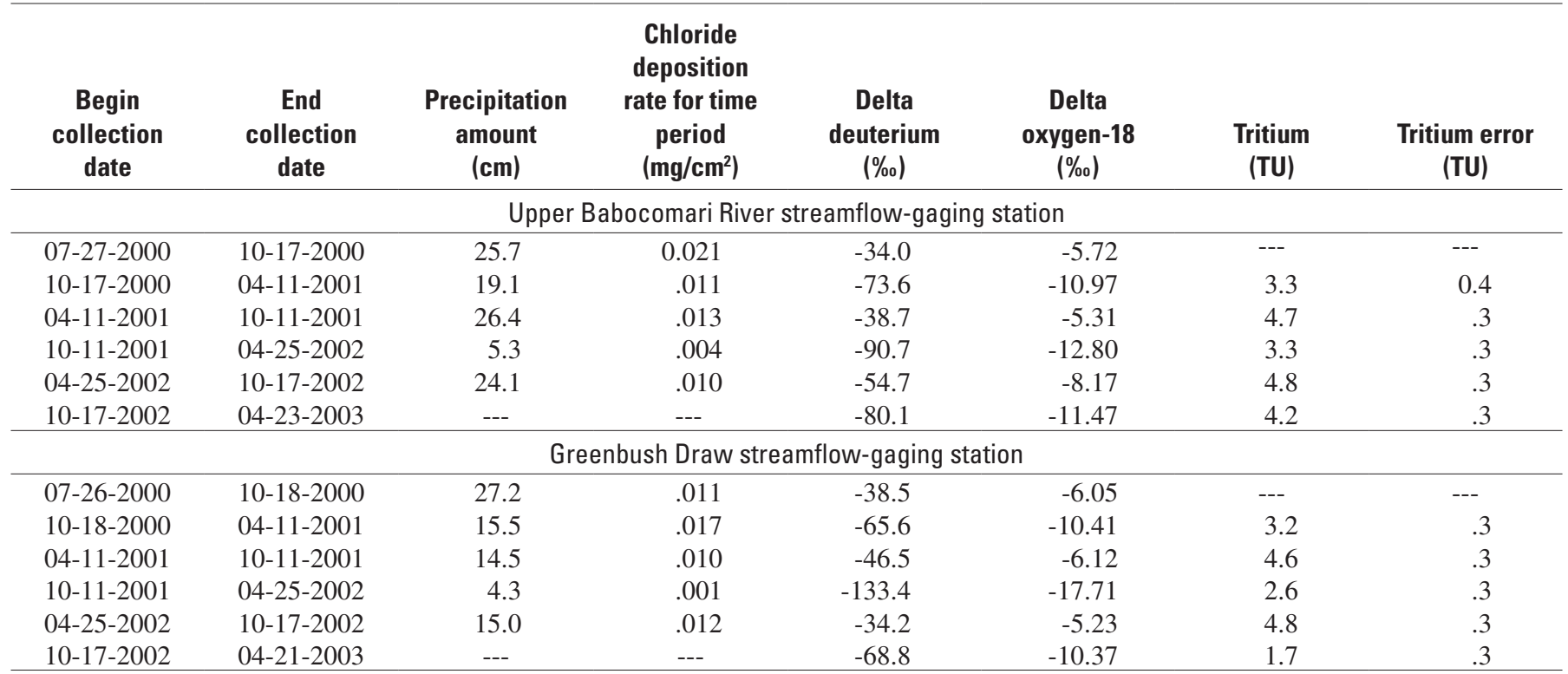

\section{Streamflow-Data Collection and Analysis}

Knowledge of ephemeral streamflow timing and duration in the tributaries was needed to determine the availability of water for ephemeral-stream channel infiltration. In this study, streamflow availability was estimated using frequency and duration of flow determined by USGS streamflow-gaging stations, ARS flumes, and temperature methods. Onset StowAway TidbiT temperature sensors were buried about $15 \mathrm{~cm}$ below the surface of streambed sediments at 7 of the 12 tributary borehole sites (table 2) and at selected channel locations between boreholes (fig. 1). Sediment temperatures were logged every 15 to 30 minutes. A rapid drop in temperature of more than $0.2^{\circ} \mathrm{C}$ indicated onset of streamflow; a low-temperature inflection point in the thermograph was interpreted as the cessation of streamflow (Constantz and others, 2001; Gungle, 2003). Durations of individual ephemeral-streamflow events ranged from 15 minutes to 48 days (table 8 ).

\section{Data-Analysis Methods}

Infiltration is defined as the flow of water from above ground into the unsaturated zone; recharge is defined as the flow of water across the regional water table. The rate of infiltration, or infiltration flux, is strongly dependent on the spatial and temporal distribution of source water and the hydraulic and physical properties of the subsurface sediments. At the onset of infiltration, the initial infiltration flux is at its highest and is extremely transient. As infiltration continues over time, the infiltration flux decreases to a nearly constant rate approaching the effective mean saturated hydraulic conductivity of the subsurface sediments.
Infiltration can lead directly to recharge when the wetting front reaches the regional water table while infiltration is still occurring. In the arid and semiarid Southwest, however, deep water tables and short infiltration times lead to infiltration ending long before the wetting front crosses the water table. In these instances, water that has infiltrated into the unsaturated zone can be removed by evapotranspiration or, if the water has moved past the root zone, remain in storage until it is displaced by water from a subsequent infiltration event. Unsaturated-zone water in storage below the root zone can continue to redistribute over time. This long-term movement of water, or percolation flux, occurs both vertically, by drainage, and horizontally in response to heterogeneity or anisotropy of the sediments. Long-term percolation can result in recharge.

\section{Unsaturated Hydraulic Properties}

Moisture-release curves describe the nonlinear decrease in soil-water content at decreasing matric potentials. The van Genuchten (1980) algebraic expression relates soil-water content to matric potential by:

$$
\begin{aligned}
& \theta_{v}=\left(1+\left(\alpha\left|h_{p}\right|\right)^{n}\right)^{-m}, \\
& \text { where } \\
& \theta_{v}=\text { volumetric soil-water content }\left[\mathrm{L}^{3} / \mathrm{L}^{3}\right] \text {, } \\
& \alpha=\text { van Genuchten fitting parameter }[1 / \mathrm{L}] \text {, } \\
& h_{p}=\text { matric potential [L], } \\
& n=\text { van Genuchten fitting parameter (dimensionless), } \\
& \text { and } \\
& m=\text { van Genuchten fitting parameter equal to } 1-1 / n \\
& \text { (dimensionless). }
\end{aligned}
$$


Table 8. Streamflow durations at streambed-temperature sensors, Agricultural Research Service flumes, and U.S. Geological Survey streamflow-gaging stations; and distance of duration-measurement locations from the mountain front, Sierra Vista subwatershed, Arizona

[hr, hours; km, kilometers; ---, no data; values in parentheses are distance from the mountain front in kilometers]

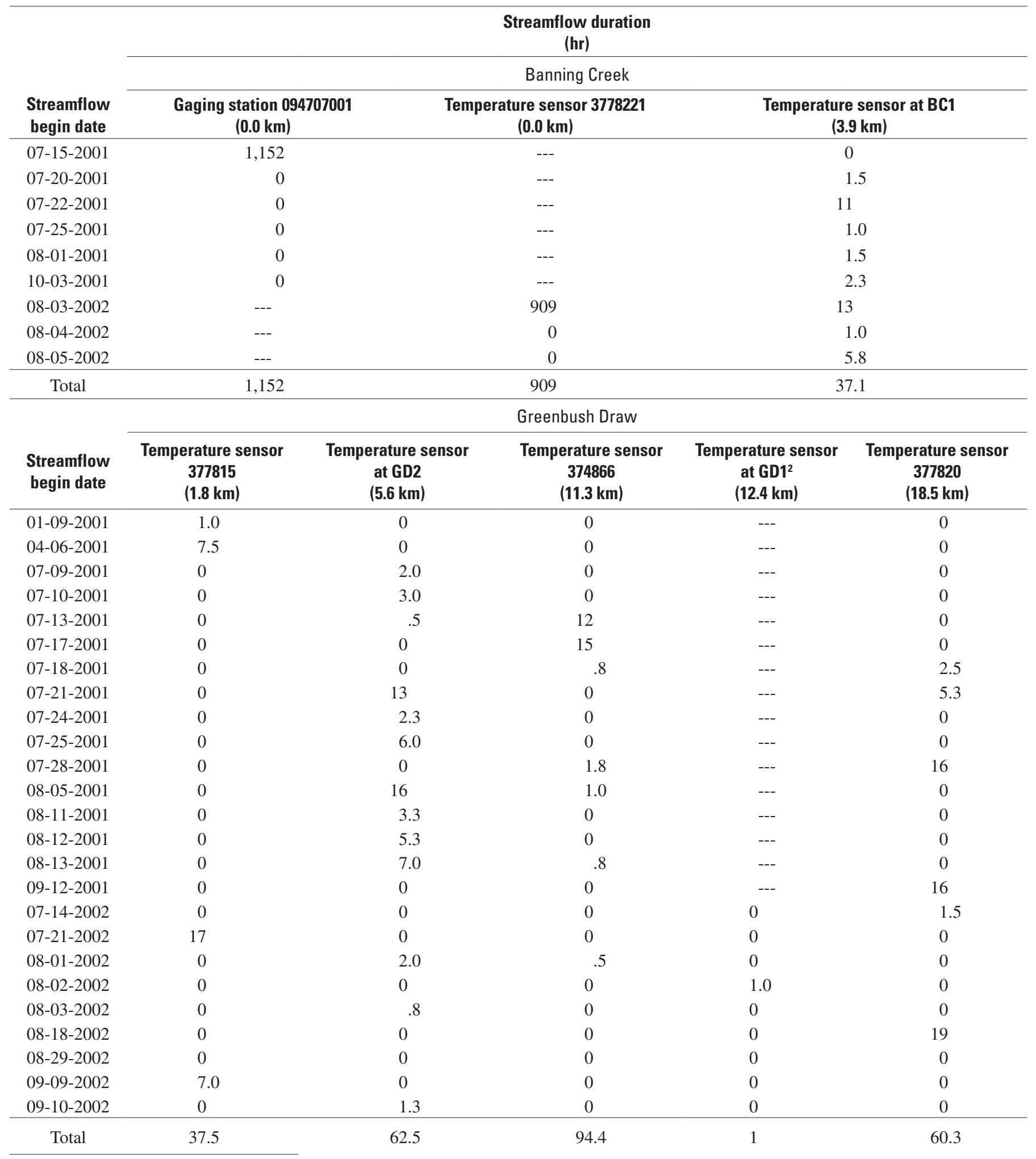

See footnotes at end of table. 
Table 8. Streamflow durations at streambed-temperature sensors, Agricultural Research Service flumes, and U.S. Geological Survey streamflow-gaging stations; and distance of duration-measurement locations from the mountain front, Sierra Vista subwatershed, Arizona-Continued

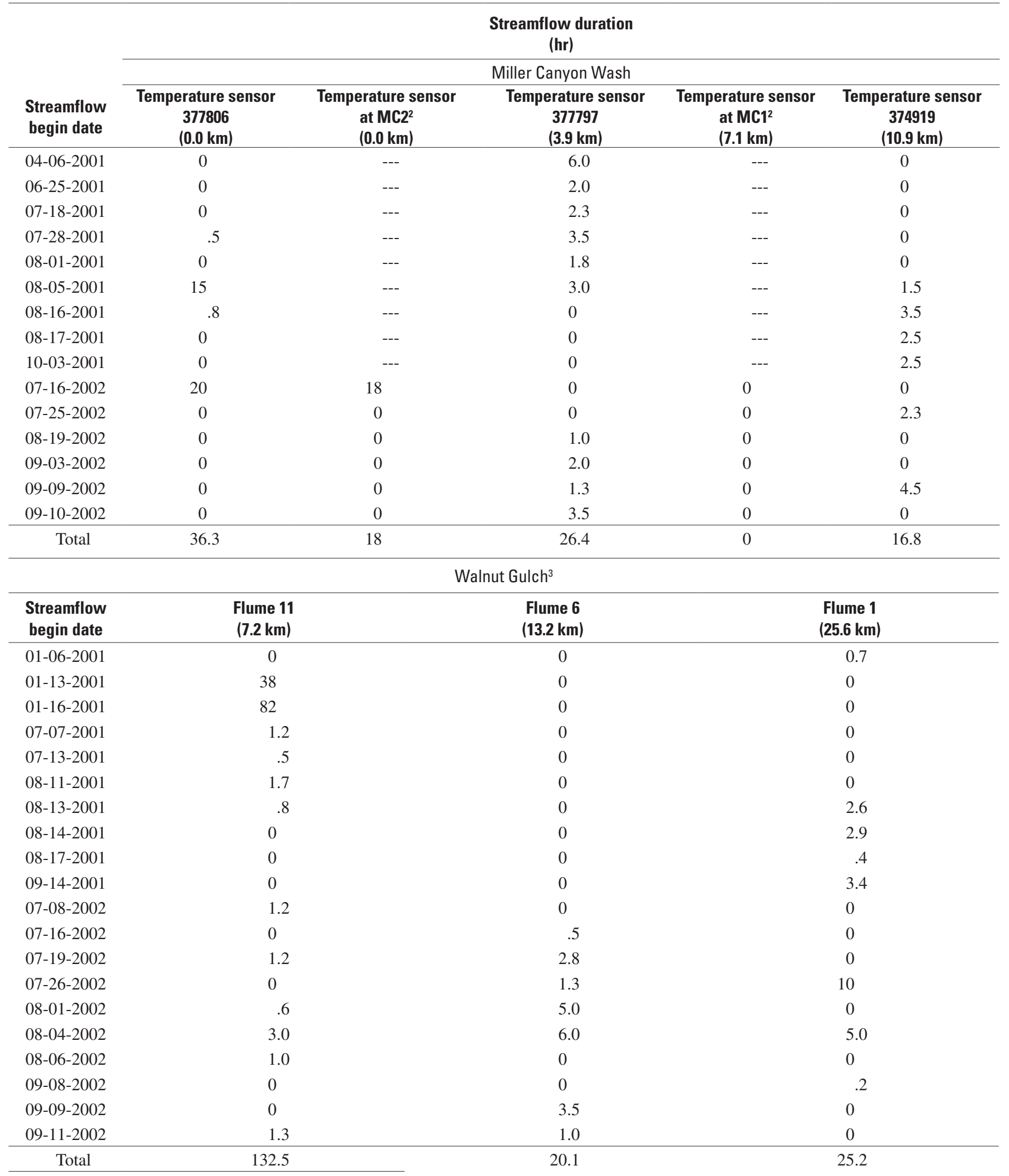

See footnotes at end of table. 
Table 8. Streamflow durations at streambed-temperature sensors, Agricultural Research Service flumes, and U.S. Geological Survey streamflow-gaging stations; and distance of duration-measurement locations from the mountain front, Sierra Vista subwatershed, Arizona-Continued

\begin{tabular}{|c|c|c|c|c|c|}
\hline & \multicolumn{5}{|c|}{$\begin{array}{l}\text { Streamflow duration } \\
\text { (hr) }\end{array}$} \\
\hline \multicolumn{6}{|c|}{ Woodcutters Wash } \\
\hline $\begin{array}{l}\text { Streamflow } \\
\text { begin date }\end{array}$ & $\begin{array}{c}\text { Temperature sensor } \\
\text { at WC4a } \\
(0.4 \mathrm{~km})\end{array}$ & $\begin{array}{c}\text { Temperature sensor } \\
375010 \\
(3.1 \mathrm{~km}) \\
\end{array}$ & $\begin{array}{c}\text { Temperature sensor } \\
\text { at WC3 } \\
(7.2 \mathrm{~km})\end{array}$ & $\begin{array}{c}\text { Temperature sensor } \\
377793 \\
(8.0 \mathrm{~km}) \\
\end{array}$ & $\begin{array}{c}\text { Temperature sensor } \\
\text { at WC1 } \\
(16.4 \mathrm{~km}) \\
\end{array}$ \\
\hline 04-05-2001 & 0 & 0 & --- & 13 & 0 \\
\hline 04-06-2001 & 0 & .5 & --- & 0 & 3.0 \\
\hline 06-19-2001 & 0 & 16 & --- & 12.5 & 0 \\
\hline $06-25-2001$ & 0 & 0 & --- & 2.0 & .3 \\
\hline 07-05-2001 & 0 & 13 & --- & 0 & 0 \\
\hline 07-07-2001 & 0 & 22 & --- & 1.5 & .5 \\
\hline 07-09-2001 & 0 & 5.0 & --- & 1.3 & 0 \\
\hline $07-16-2001$ & 0 & 0 & --- & 0 & .8 \\
\hline $07-24-2001$ & 0 & 5.0 & --- & 0 & 0 \\
\hline $07-25-2001$ & 0 & 7.5 & --- & 0 & 0 \\
\hline $07-28-2001$ & 0 & 13 & --- & 2.8 & .3 \\
\hline 08-01-2001 & 0 & 1.0 & --- & 0 & 0 \\
\hline 08-05-2001 & 0 & 2.0 & --- & 0 & 0 \\
\hline 08-11-2001 & 0 & 7.5 & --- & 0 & 0 \\
\hline 08-13-2001 & .5 & 6.5 & --- & 0 & 14 \\
\hline 08-14-2001 & 0 & 1.5 & --- & 0 & 0 \\
\hline 08-16-2001 & 0 & 2.0 & --- & 0 & 0 \\
\hline $08-17-2001$ & 0 & 8.5 & --- & 0 & 4.5 \\
\hline 08-29-2001 & 0 & 5.5 & --- & 0 & 12 \\
\hline $09-12-2001$ & 0 & 6.5 & --- & 0 & 0 \\
\hline 07-08-2002 & 0 & 1.0 & 2.5 & .8 & 12 \\
\hline $07-16-2002$ & 0 & .5 & 1.5 & 1.0 & .5 \\
\hline $07-18-2002$ & 0 & 0 & 0 & 0 & .8 \\
\hline $07-26-2002$ & 0 & 0 & 0 & 0 & 2.0 \\
\hline 08-03-2002 & 0 & 0 & 2.0 & 0 & 0 \\
\hline $08-08-2002$ & 0 & 0 & 0 & 0 & 1.8 \\
\hline $08-16-2002$ & 0 & 0 & 0 & 0 & .8 \\
\hline $08-19-2002$ & 0 & 0 & 1.0 & 1.0 & .8 \\
\hline 09-08-2002 & 0 & 0 & 0 & 0 & 15 \\
\hline 09-09-2002 & 0 & 0 & 0 & 0 & 3.3 \\
\hline $10-07-2002$ & 0 & 0 & 1.5 & 2.5 & 1.0 \\
\hline Total & 0.5 & 124.5 & 8.5 & 38.4 & 73.4 \\
\hline
\end{tabular}

${ }^{1}$ Streamflow-gaging station 09470700 and temperature sensor 377822 are at the same location.

${ }^{2}$ Data not used in analysis of streamflow duration versus distance from the mountain front.

${ }^{3}$ Provisional data provided by the U.S. Department of Agriculture, Agricultural Research Service, Southwest Watershed Research Center. 
For this study, the pressures (in cm water) at which soil-water contents were determined are considered to be equivalent to matric potentials.

The RETC (RETention Curve) computer code (van Genuchten and others, 1991) was used to fit moisture-release curves to the induced-pressure and measured water-content data to determine the van Genuchten fitting parameters of $\alpha$ and $n$ (table 6). All curves were fit so that their coefficients of determination $\left(R^{2}\right)$ for the regression of the measured values versus the fitted values were greater than 0.95 . Volumetric residual and saturated soil-water contents $\left(\theta_{R}\right.$ and $\theta_{S}$, in $\left.\mathrm{L}^{3} / \mathrm{L}^{3}\right)$ were also determined using the RETC code.

\section{Unsaturated-Zone Chloride Mass Balance}

The mass of chloride $(\mathrm{Cl})$ in the unsaturated zone can be used to estimate long-term vertical water movement. Chloride is continuously deposited on the land surface by precipitation and dry fallout. The high solubility of $\mathrm{Cl}$ enables its transport into the subsurface by infiltrating water. Because $\mathrm{Cl}$ is essentially nonvolatile and $\mathrm{Cl}$ uptake by plants is minimal, $\mathrm{Cl}$ is retained in the sediment when water is removed by evaporation and transpiration. An increase in $\mathrm{Cl}$ within the root zone of the shallow subsurface, therefore, is proportional to the amount of water lost by evapotranspiration (Allison and Hughes, 1978). In areas where active infiltration is occurring, an increase in $\mathrm{Cl}$ in the shallow subsurface will generally be absent, and concentrations will be very low through the unsaturated zone. In areas where little to no active infiltration is occurring, an increase in $\mathrm{Cl}$ in the shallow subsurface will be present, and concentrations will be relatively high through the unsaturated zone.

If the $\mathrm{Cl}$ deposition rate on the land surface is known, the average travel time of $\mathrm{Cl}\left(t_{C l}\right.$; in $\left.\mathrm{t}\right)$ to a depth in the unsaturated zone $(z$, in $\mathrm{L})$ can be calculated by:

$$
t_{C l}=\frac{\int_{0}^{z} C l_{\text {soil }} d z}{C l_{d e p}},
$$

where

$C l_{\text {soil }}=$ chloride mass in the sample interval $\left[\mathrm{M} / \mathrm{L}^{3}\right]$, and $C l_{d e p}=$ chloride deposition rate $\left[\mathrm{M} / \mathrm{L}^{2} / \mathrm{t}\right]$.

The above calculation entails several assumptions: (1) flow in the unsaturated zone is downward-vertical and piston type, (2) bulk precipitation (precipitation plus dry fallout) is the only source of $\mathrm{Cl}$ and there are no mineral sources of $\mathrm{Cl}$, (3) the $\mathrm{Cl}$ deposition rate has stayed constant over time, and (4) there is no recycling of $\mathrm{Cl}$ within the unsaturated zone.

This model of $\mathrm{Cl}$ movement predicts that in interdrainage areas with little to no infiltration, $\mathrm{Cl}$ concentrations should increase through the root zone and then remain constant down to the water table. Numerous published chloride profiles, however, show that $\mathrm{Cl}$ concentrations commonly decrease below the peak concentration in the root zone. Some of the above assumptions, therefore, may not be valid for all unsaturated-zone systems. The decrease in $\mathrm{Cl}$ concentrations below the peak has been attributed to nonpiston flow (Sharma and Hughes, 1985), ground-water dilution (Allison and others, 1985), or nonsteady flow as a result of paleoclimatic variations (Phillips and Stone, 1985; Scanlon, 1991).

For some geomorphic settings, such as ephemeral streams, assumption 2 is not valid because streamflow provides an additional source of $\mathrm{Cl}$ to the subsurface. To correctly determine travel time below ephemeral streams with the $\mathrm{Cl}$ mass balance method, the mass of $\mathrm{Cl}$ in streamflow needs to be included in equation 4. In this study, ephemeral streamflow discharges and $\mathrm{Cl}$ concentrations were not quantified; therefore, the $\mathrm{Cl}$ mass method was not used to determine travel times below ephemeral streams.

Chloride deposition rates in the Sierra Vista subwatershed were determined from the composite precipitation samples collected for this study (table 7). Annual rates ranged from 0.011 to $0.032 \mathrm{mg} / \mathrm{cm}^{2} \cdot \mathrm{yr}$. The average annual $\mathrm{Cl}$ deposition rate for the subwatershed was determined to be $0.022 \mathrm{mg} / \mathrm{cm}^{2} \cdot \mathrm{yr}$.

\section{Meteoric Tritium}

Tritium $\left({ }^{3} \mathrm{H}\right)$, a naturally occurring radioactive isotope of hydrogen, can be used to estimate the age of subsurface water and infiltration fluxes into the subsurface. Large quantities of tritium were released to the atmosphere during thermonuclearweapons testing from 1952 until the late 1960s; maximum releases occurred in the early 1960s. As a result, the amount of tritium in precipitation sharply increased during testing as tritium was introduced into the water cycle, and decreased after testing ended. The amount of tritium in subsurface water at a given time is a function of the amount of tritium in the atmosphere when infiltration occurred and the radioactivedecay rate of tritium. If flow in the unsaturated zone is assumed to be downward-vertical and piston type, the average infiltration flux $\left(q_{i}\right.$, in L/T) can be estimated by:

$$
q_{i}=\frac{\Delta z}{\Delta t} \theta_{v}
$$

where

$$
\begin{aligned}
\Delta z= & \text { depth of maximum tritium activity }[\mathrm{L}], \\
\Delta t= & \text { elapsed time between sampling and maximum } \\
& \text { atmospheric tritium activity }[\mathrm{t}] \text { (38 years for this } \\
& \text { study), and } \\
\theta_{v}= & \text { volumetric soil-water content }\left[\mathrm{L}^{3} / \mathrm{L}^{3}\right] .
\end{aligned}
$$

Tritium activity in the composite precipitation samples collected during this study ranged from 1.7 to $4.2 \mathrm{TU}$ for winter precipitation and from 4.6 to $4.8 \mathrm{TU}$ for summer precipitation (table 7). Pore water having a tritium activity within this range was, therefore, considered to be recent infiltration. Pore water having an activity of less than $0.5 \mathrm{TU}$ was considered to have infiltrated prior to 1952. 


\section{Stable Isotopes}

The stable-isotope ratios of oxygen $\left({ }^{18} \mathrm{O} /{ }^{16} \mathrm{O}\right)$ and hydrogen $\left({ }^{2} \mathrm{H} /{ }^{1} \mathrm{H}\right)$ can be used to estimate seasonal cycles of infiltration and to determine if pore water has undergone evaporation. Ratios determined in this study are reported relative to Vienna Standard Mean Ocean Water (VSMOW). Differences from the standard are expressed by delta notation $(\delta)$ in per mil (\%o). The delta notation is computed by:

$$
\delta=\left[\frac{R_{x}-R_{S t d}}{R_{S t d}}\right] \cdot 1,000,
$$

where

$$
\begin{aligned}
R_{x} & =\text { ratio of isotopes measured in the sample, and } \\
R_{S t d} & =\text { ratio of same isotopes in standard. }
\end{aligned}
$$

The relation between $\delta^{18} \mathrm{O}$ and $\delta^{2} \mathrm{H}$ in precipitation can be represented by the global meteoric water line:

$$
\delta^{2} \mathrm{H}=8 \delta^{18} \mathrm{O}+10(\text { Craig, 1961) } .
$$

Mass differences between ${ }^{18} \mathrm{O}$ and ${ }^{16} \mathrm{O}$ and between ${ }^{2} \mathrm{H}$ and ${ }^{1} \mathrm{H}$ enable isotopic fractionation during phase changes, such as evaporation. Water molecules consisting of ${ }^{16} \mathrm{O}$ and ${ }^{1} \mathrm{H}$ evaporate preferentially, resulting in water enriched in ${ }^{18} \mathrm{O}$ and ${ }^{2} \mathrm{H}$.

Lines describing the relation between $\delta^{18} \mathrm{O}$ and $\delta^{2} \mathrm{H}$ in enriched water have smaller slopes than the slope of the global meteoric water line.

The amount of each isotope in precipitation is dependant on the temperature and source location of the precipitation. Because precipitation temperatures and sources vary by season in the Sierra Vista subwatershed, stable-isotope values in precipitation show seasonal variation. The $\delta^{18} \mathrm{O}$ for the composite precipitation samples collected for this study ranged from -5.23 to $-8.17 \%$ o for summer precipitation and from -10.37 to $-17.71 \%$ for winter precipitation (table 7). The $\delta^{2} \mathrm{H}$ ranged from -34.0 to $-54.7 \%$ for summer precipitation and from -65.6 to $-133.4 \%$ o for winter precipitation (table 7 ).

\section{Heat as a Tracer}

Sediment-temperature profiles can be used to estimate one-dimensional infiltration fluxes in the unsaturated zone below the beds of ephemeral-stream channels (Constantz and Thomas, 1996; Constantz and others, 2003). Temperatures of streambed surfaces are predominantly influenced by heating from solar radiation and ambient air temperatures. Beneath dry streambeds, shallow sediment temperatures vary diurnally and seasonally in response to downward conductive heat transport. Deeper sediment temperatures are less affected by diurnal or seasonal air temperatures, and, therefore, do not greatly vary over time. During periods of stream-channel infiltration, heat transport into the subsurface by advection predominates and transport by conduction is considered negligible.
An analytical method (Taniguchi and Sharma, 1990; Constantz and Thomas, 1996) was used as a first approximation to calculate infiltration flux $\left(q_{i}\right.$, in $\left.\mathrm{L} / \mathrm{t}\right)$ from measured sediment temperatures at each ephemeral-stream site (table 9):

$$
q_{i}=\frac{\Delta z}{\Delta t} \frac{\rho_{b_{s o i}} C_{s}}{\rho_{b_{\text {water }}} C_{w}},
$$

where

$$
\begin{aligned}
\Delta z= & \text { vertical distance between temperature } \\
& \text { sensors }[\mathrm{L}], \\
\Delta t= & \text { travel time of the temperature perturbation } \\
& \text { between sensors }[\mathrm{t}], \\
\rho_{b_{s o i l}}= & \text { bulk density of sediment }\left[\mathrm{M} / \mathrm{L}^{3}\right], \\
C_{s}= & \text { heat capacity of the dry sediment }\left[\mathrm{E} / \mathrm{L}^{3} / \mathrm{T}\right], \\
\rho_{b_{\text {water }}=}= & \text { bulk density of water }\left[\mathrm{M} / \mathrm{L}^{3}\right], \text { and } \\
C_{w}= & \text { heat capacity of water }\left[\mathrm{E} / \mathrm{L}^{3} / \mathrm{T}\right] .
\end{aligned}
$$

Onset of streamflow was determined from streambed-temperature data. The distance between temperature sensors was known for each borehole, and the travel time of the temperature signal was measured. The $\rho_{b}$ and $C_{S}$ of the sediment were determined from cores. For depth intervals where more than one property value was available, average values were used. The $\rho_{b_{\text {water }}}$ is a constant $1.0 \mathrm{~g} / \mathrm{cm}^{3}$, and the $C_{W}$ is a constant $4.2 \cdot 10^{6} \mathrm{~J} / \mathrm{m}^{3} \cdot{ }^{\circ} \mathrm{C}$.

The infiltration flux determined by the use of the analytical method represents the initial, transient infiltration flux. This method is only valid for cases where pore-water velocities are high enough that heat transport by conduction is negligible compared with heat transport by advection. The high $K_{s}$ values determined for stream-alluvium cores indicate that this situation is typical for most of the subsurface sediments beneath ephemeral-stream channels in the Sierra Vista subwatershed. The analytical method is also only valid for infiltration under nonisothermal, continuous-streamflow loss; this condition is assumed in the ephemeral-stream channels.

A more comprehensive, rigorous numerical approach was used to account for heat transport with water flow in the unsaturated zone. Convective and advective heat transport can be expressed by:

$$
\begin{aligned}
& \frac{d}{d t}\left[\theta_{v} C_{w}+(1-\Phi) C_{s}\right] \\
& =\frac{d}{d z}\left[K_{t}(\theta) \frac{d T}{d z}\right] \\
& +\frac{d}{d z}\left(\theta C_{w} D_{h} \frac{d T}{d z}\right)-\frac{d}{d z}\left(\theta C_{w} T q_{w}\right)
\end{aligned}
$$

where

$$
\begin{aligned}
\theta_{v} & =\text { volumetric soil-water content }\left[\mathrm{L}^{3} / \mathrm{L}^{3}\right] \\
K_{t} & =\text { thermal conductivity }[\mathrm{E} / \mathrm{t} / \mathrm{L} / \mathrm{T}], \\
T & =\text { temperature }[\mathrm{T}], \text { and } \\
D_{h} & =\text { a thermomechanical dispersion tensor }\left[\mathrm{L}^{2} / \mathrm{t}\right]
\end{aligned}
$$


Table 9. Streamflow characteristics and input parameters used for the infiltration-flux analytical method using heat as a tracer, Sierra Vista subwatershed, Arizona

$\left[\mathrm{m}\right.$, meters; hr, hour; $\mathrm{g} / \mathrm{cm}^{3}$, grams per cubic centimeter; $\mathrm{J} / \mathrm{m}^{3}{ }^{\circ} \mathrm{C}$, joules per cubic meter degrees Celsius; $\mathrm{m} / \mathrm{hr}$, meters per hour;

Flux type: Infiltration, infiltration flux; Percolation, percolation flux; NC, not calculated]

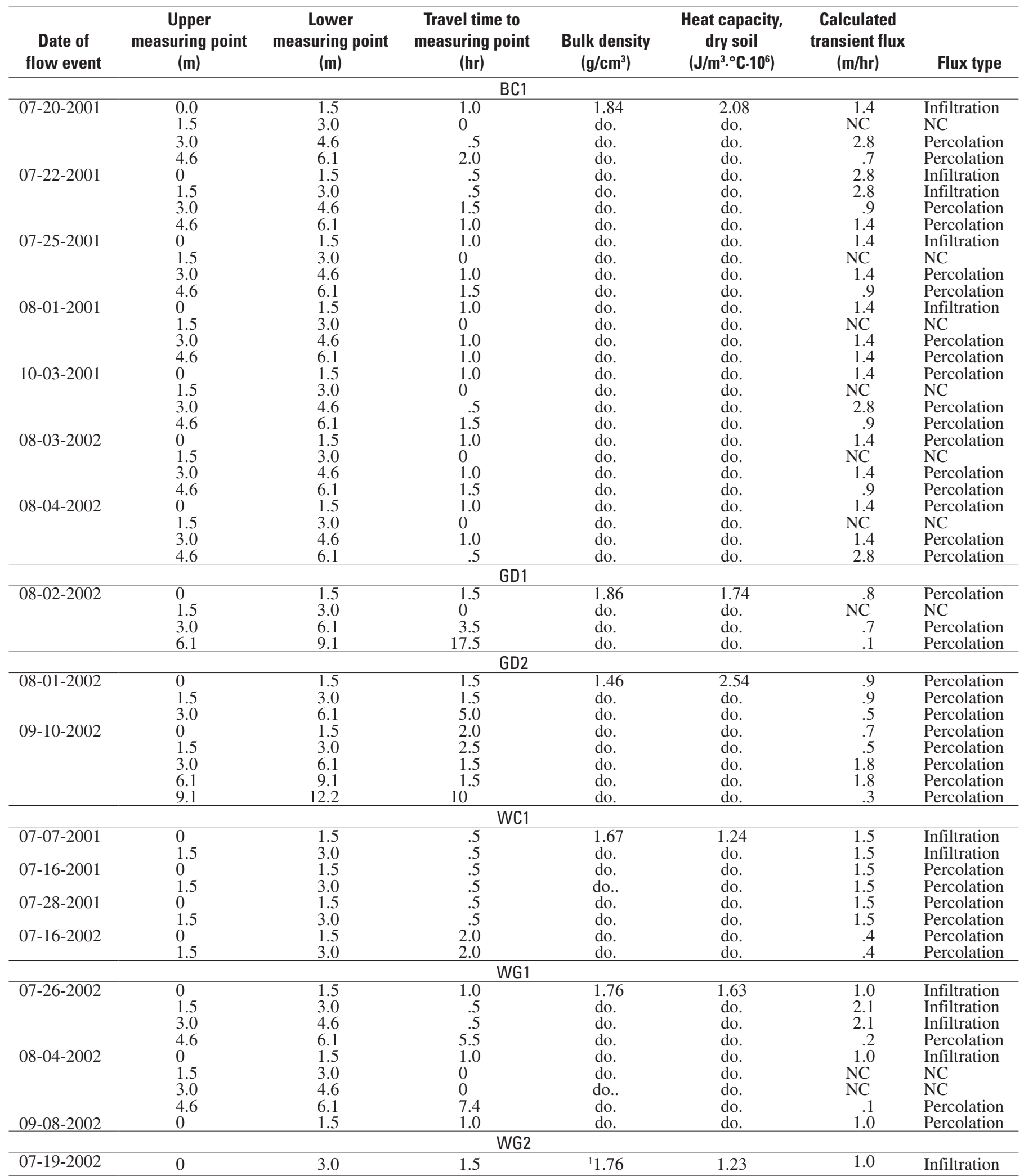

${ }^{1}$ Estimated on the basis of the value for borehole WG1. 
To describe water flow in the unsaturated zone, variably saturated ground-water flow can be expressed by:

$$
\begin{aligned}
& \frac{d \theta(z, t)}{d t} \\
& =\frac{d}{d z}\left[K_{u}\left(h_{p}, z\right) \frac{d h(z, t)}{d z}\right] \quad \text { (Richards, 1931), }
\end{aligned}
$$

where

$$
\begin{aligned}
K_{u} & =\text { unsaturated hydraulic conductivity }[\mathrm{L} / \mathrm{t}] \\
h_{p} & =\text { matric potential }[\mathrm{L}], \text { and } \\
h & =\text { total head }[\mathrm{L}] .
\end{aligned}
$$

The numerical code VS2DH (Healy and Ronan, 1996) and its graphical user interface (Hsieh and others, 2000) were used to solve equations 9 and 10 simultaneously.

One-dimensional numerical models were developed to represent conceptual fluid flow and heat transfer at each ephemeral-stream site (tables 10 and 11). Models were created only for sites and times where temperature perturbations were detected at depth during streamflow events. Models were not created for sites and events where temperature perturbations were not detected until after streamflow ended. Similarly, simulations were terminated at the end of streamflow because at that point, heat transfer is dominated by both water and

\begin{tabular}{|c|c|c|c|c|c|c|c|c|c|c|c|}
\hline Borehole & $\begin{array}{l}\text { Depth } \\
\text { to top of } \\
\text { domain } \\
\text { (m) }\end{array}$ & $\begin{array}{l}\text { Depth to } \\
\text { bottom of } \\
\text { domain } \\
\text { (m) }\end{array}$ & $\begin{array}{c}\text { Initial } \\
\text { saturated } \\
\text { hydraulic } \\
\text { conductivity } \\
\text { (cm/s) }\end{array}$ & $\begin{array}{l}\text { Adjusted } \\
\text { saturated } \\
\text { hydraulic } \\
\text { conductivity } \\
\text { (cm/s) }\end{array}$ & $\begin{array}{c}\text { Porosity } \\
\left(\mathrm{cm}^{3} / \mathrm{cm}^{3}\right)\end{array}$ & $\begin{array}{c}\text { Residual } \\
\text { water } \\
\text { content } \\
\left(\mathrm{cm}^{3} / \mathrm{cm}^{3}\right)\end{array}$ & $\begin{array}{c}\alpha \\
(1 / \mathrm{cm})\end{array}$ & $\begin{array}{c}\mathbf{n} \\
\text { (dimen- } \\
\text { sionless) }\end{array}$ & $\begin{array}{c}\text { Thermal } \\
\text { conductivity, } \\
\text { saturation' } \\
\left(\mathrm{W} / \mathrm{m}^{\circ}{ }^{\circ} \mathrm{C}\right)\end{array}$ & $\begin{array}{l}\text { Thermal } \\
\text { conductivity, } \\
\text { residual } \\
\text { water } \\
\text { content } \\
\left(\mathrm{W} / \mathrm{m}^{\circ} \mathrm{C}\right)\end{array}$ & $\begin{array}{c}\text { Heat } \\
\text { capacity, } \\
\text { dry soil } \\
\left(\mathrm{J} / \mathrm{m}^{3} \cdot{ }^{\circ} \mathrm{C} \cdot 10^{6}\right)\end{array}$ \\
\hline $\mathrm{BC} 1$ & 0.0 & 3.0 & $9.6 \cdot 10^{-3}$ & $1.5 \cdot 10^{-2}$ & 0.34 & 0.10 & 0.145 & 1.9 & 2.5 & 2.1 & 2.08 \\
\hline WG1 & 0 & 4.6 & $3.3 \cdot 10^{-2}$ & $3.5 \cdot 10^{-2}$ & .39 & .05 & .145 & 1.4 & 2.5 & .9 & 1.63 \\
\hline WG2 & 0 & 3.0 & $23.3 \cdot 10^{-2}$ & $3.5 \cdot 10^{-2}$ & ${ }^{2} .39$ & ${ }^{2} .05$ & ${ }^{2} .145$ & ${ }^{2} 1.4$ & 2.5 & .8 & 1.23 \\
\hline
\end{tabular}
vapor flux, a condition VS2DH cannot simulate.

Table 10. Sediment properties used for the VS2DH numerical simulations, Sierra Vista subwatershed, Arizona

$\left[\mathrm{m}\right.$, meters; $\mathrm{cm} / \mathrm{s}$, centimeters per second $; \mathrm{cm}^{3} / \mathrm{cm}^{3}$, cubic centimeters per cubic centimeters; $1 / \mathrm{cm}$, inverse centimeters; $\mathrm{W} / \mathrm{m} \cdot{ }^{\circ} \mathrm{C}$, watts per meter degrees Celsius; $\mathrm{J} / \mathrm{m}^{3} \cdot{ }^{\circ} \mathrm{C}$, joules per cubic meter degrees Celsius]

\begin{tabular}{|c|c|c|c|c|c|c|c|c|c|}
\hline \multirow[b]{2}{*}{ Borehole } & \multirow[b]{2}{*}{$\begin{array}{l}\text { Simulation } \\
\text { date }\end{array}$} & \multicolumn{5}{|c|}{$\begin{array}{l}\text { Initial sediment temperature condition } \\
\qquad\left({ }^{\circ} \mathrm{C}\right)\end{array}$} & \multirow{2}{*}{$\begin{array}{c}\begin{array}{c}\text { Initial hydraulic } \\
\text { condition }\end{array} \\
\text { Water } \\
\text { content }^{1} \\
\left(\mathrm{~cm}^{3} / \mathrm{cm}^{3}\right)\end{array}$} & \multicolumn{2}{|c|}{ Transport boundary condition } \\
\hline & & $0.0 \mathrm{~m}$ & $1.5 \mathrm{~m}$ & $3.0 \mathrm{~m}$ & $4.6 \mathrm{~m}$ & $6.1 \mathrm{~m}$ & & $\begin{array}{c}\text { Temperature } \\
\text { of inflow } \\
\left({ }^{\circ} \mathrm{C}\right)\end{array}$ & $\begin{array}{c}\text { Flux into } \\
\text { domain² } \\
(\mathrm{m} / \mathrm{hr})\end{array}$ \\
\hline $\mathrm{BC} 1$ & 07-20-2001 & 29.5 & 23.7 & 19.6 & --- & --- & 0.15 & 24.0 & 0.5 \\
\hline WC1 & 07-07-2001 & 26.2 & 25.0 & 21.0 & --- & --- & .07 & 24.0 & 1.3 \\
\hline \multirow[t]{2}{*}{ WG1 } & 07-26-2002 & 28.7 & 25.9 & 23.4 & 21.5 & --- & .10 & 25.0 & .5 \\
\hline & 08-04-2002 & 26.8 & 25.7 & 24.2 & 22.6 & --- & .20 & 25.0 & .4 \\
\hline
\end{tabular}

${ }^{1}$ Estimated from thermal conductivity at field conditions.

${ }^{2}$ Estimated on the basis of values for borehole WG1.

Table 11. Initial and boundary conditions for the VS2DH numerical simulations, Sierra Vista subwatershed, Arizona

[m, meters; ${ }^{\circ} \mathrm{C}$, degrees Celsius; $\mathrm{cm}^{3} / \mathrm{cm}^{3}$, cubic centimeter per cubic centimeter; $\mathrm{m} / \mathrm{hr}$, meters per hour; ---, no data]

${ }^{1}$ Estimated from soil-water content at time of sampling.

${ }^{2}$ Determined through calibration. 
Sediment properties were determined from core measurements. For depth intervals where more than one property value was measured, average values were used in the calculation. Thermal conductivities at saturation were estimated on the basis of measured thermal conductivities at ambient conditions (table 5). All layers were assumed to be isotropic and to have a specific storage of zero. Streamflow water temperatures were determined from values measured by the surface temperature sensors. Upper boundaries were defined as no flow for the hour prior to the onset of flow, and then as specified normal-flux boundaries during streamflow. Initial sediment temperatures were determined from values measured by temperature sensors at depth. Initial hydraulic conditions were estimated as soil-water contents. Lower boundaries were defined as possible seepage faces. Onset and length of streamflow were determined from streambed sediment-temperature data.

The model simulations yielded subsurface sediment temperatures due to advective heat transport. In all cases, the saturated hydraulic conductivity had to be adjusted to accurately simulate the temperature inflection point identifying streamflow arrival time (table 10). The models were calibrated by adjusting the specified infiltration flux at the upper boundary to minimize the difference between the calculated and the measured sediment temperatures at depth.

The infiltration flux calibrated for the upper boundary represents an average value of the initial, transient infiltration flux. The model simulations represent infiltration from streamflow events ranging in duration from 1 to 5.5 hours; long-term constant infiltration rates were probably not achieved during these ephemeral streamflows.

\section{Rates of Ephemeral-Stream Channel Recharge}

Recharge deriving from ephemeral streamflow along the length of a channel can be estimated by:

$$
R=\int_{0}^{\ell}\left(S w q_{i}-E V-T\right) d \ell,
$$

where

$$
\begin{aligned}
R= & \text { recharge }\left[\mathrm{L}^{3}\right], \\
S= & \text { streamflow duration }[\mathrm{t}], \\
w= & \text { wetted width of channel }[\mathrm{L}], \\
q_{i}= & \text { infiltration flux }[\mathrm{L} / \mathrm{t}], \\
E V= & \text { water lost to channel evaporation per channel } \\
& \text { length }\left[\mathrm{L}^{3} / \mathrm{L}\right], \\
T= & \text { water lost to near-channel transpiration per } \\
& \text { channel length }\left[\mathrm{L}^{3} / \mathrm{L}\right], \text { and } \\
\ell= & \text { length of channel containing alluvial sediments } \\
& {[\mathrm{L}] . }
\end{aligned}
$$

Average annual recharge was determined by dividing the calculated recharge rate for the 2001-2002 period by the number of years in the time period ( 2 years for this study). The total streamflow duration was determined for the 2-year period at each streambed-temperature sensor, ARS flume, and USGS streamflow-gaging station (table 8), and an exponential best-fit relation between streamflow duration and distance in the channel downstream from the mountain front was then developed for each channel (fig. 7). Only sites having streamflow-duration data for the entire 2001-2002 period were used. The width of the channel at each borehole was known (table 2), and was linearly extrapolated between boreholes. The averaged wetted-channel width during flow events was determined to be between 10 and 20 percent of the channel width on the basis of the effective wettedchannel width along a portion of Walnut Gulch as estimated by Goodrich and others (2004). An average wetted-channel width of 15 percent of the channel width was used in the calculations. Goodrich and others (2004) also estimated channel evaporation losses and near-channel transpiration losses for 1999 and 2000 along a 6.8-km reach of Walnut Gulch. The average losses were scaled so that channel evaporation was represented by $3.0 \cdot 10^{-4} \mathrm{hm}^{3} / \mathrm{km} / 2 \mathrm{yr}$ and nearchannel transpiration was represented by $1.4 \cdot 10^{-2} \mathrm{hm}^{3} / \mathrm{km} / 2 \mathrm{yr}$. These values were used for all the channels in the 2001-2002 calculations

Ephemeral-stream channel recharge rates determined with equation 11 were compared with rates derived using other independent methods (channel-reach water balance, chloride mass balance, ground-water mounding model, and microgravity measurements) for a $6.8-\mathrm{km}$ reach of Walnut Gulch (Goodrich and others, 2004). The infiltration flux used in this comparison was the lowest one calculated for Walnut Gulch by sediment-temperature analysis. As previously stated, streamflow events for which infiltration fluxes could be determined were all less than 5.5 hours in duration; the calculated infiltration fluxes represent an average value of the initial, transient infiltration fluxes. The lowest calculated infiltration fluxes are assumed to best represent the steady-state infiltration rate. Calculations of recharge for 1999 were $0.44 \mathrm{hm}^{3}$ using equation 11 and 0.14 to $0.47 \mathrm{hm}^{3}$ using other methods.Recharge calculations for 2000 were $0.16 \mathrm{hm}^{3}$ using equation 11 and 0.13 to $0.37 \mathrm{hm}^{3}$ using other methods. These results validate the assumption that the lowest calculated infiltration flux can represent the steady-state infiltration flux when determining ephemeral-stream channel recharge. 


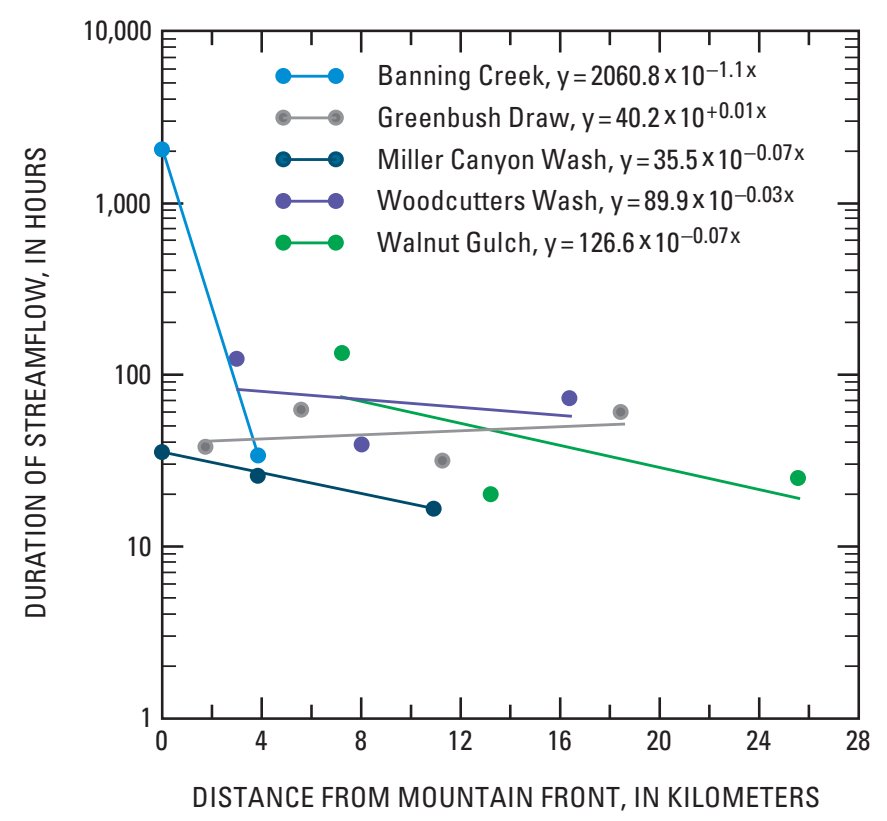

Figure 7. Regression of streamflow duration to distance from the mountain front, 2001 and 2002, Sierra Vista subwatershed, Arizona.

\section{Ephemeral-Stream Channel Infiltration}

Infiltration fluxes during streamflow events and percolation fluxes immediately following those events were determined for sites in Woodcutters Wash, Miller Canyon Wash, Walnut Gulch, Banning Creek, and Greenbush Draw. Data used in the determination of fluxes included physical, hydraulic, and thermal properties of sediment; chloride concentrations of sediment; pore-water stable-isotope values and tritium activity; neutron soil-moisture and EMI logs; and sediment-temperature and water-level monitoring. Where possible, fluxes through the upper 1.5 to $12.2 \mathrm{~m}$ of sediments were estimated.

\section{Woodcutters Wash}

Woodcutters Wash is a northeast-trending channel with headwaters in the Huachuca Mountains. The channel is $23.0 \mathrm{~km}$ long and has an average slope of $13.9 \mathrm{~m} / \mathrm{km}$. The channel widens from less than $1 \mathrm{~m}$ along the upper reaches to more than $20 \mathrm{~m}$ along the lower reaches. It is incised less than $0.5 \mathrm{~m}$ along the upper reaches and $2 \mathrm{~m}$ or more along the lower reaches. Several knickpoints occur along the lower onehalf of the channel in an area where the stream has cut through several layers of clay and caliche.
The channel drains a $37.5-\mathrm{km}^{2}$ area that ranges in elevation from 1,204 to 2,488 m. Desert scrub and grassland are the primary land-cover types in the drainage basin; mesquite is dominant along the mountain fronts and oak woodland is dominant in the mountainous areas (fig. 2). About 1 percent of the drainage basin, the central part, is urban. The banks of Woodcutters Wash have been stabilized in this area.

Soils in the drainage basin vary from loamy soils near the mountains to calcium carbonate and clayey soils downgradient. Along the stream channel, soils are sandy (fig. 3). Thickness of permeable stream alluvium is about $1 \mathrm{~m}$ near the mountains, a few centimeters within Sierra Vista, and about $3 \mathrm{~m}$ in the lower reaches of Woodcutters Wash. The stream alluvium is underlain by the compacted clayey gravels of the Pantano Formation near the mountains; the poorly sorted sand, silt, and clay of the basin fill in the Sierra Vista area; and the low-permeability silt and clay, and calcium carbonate of the basin fill along the lower reaches of the wash.

Ephemeral streamflows recorded from 2001 to 2002 in Woodcutters Wash ranged in duration from about $15 \mathrm{~min}$ to $22 \mathrm{hr}$ (table 8). Flows in the upper reaches generally were more frequent and were of a longer duration than flows in reaches downstream (fig. 7). The farthest upstream temperature sensor, 375010, detected 19 flows, which had an average duration of $6.5 \mathrm{hr}$. The farthest downstream temperature sensor, at site $\mathrm{WC} 1$, detected 18 flows, which had an average duration of $4.0 \mathrm{hr}$.

Borehole WC4a is the farthest upstream site in Woodcutters Wash and is about $0.4 \mathrm{~km}$ from the base of the Huachuca Mountains. The site is in a reach about $0.5 \mathrm{~m}$ wide and incised less than $1 \mathrm{~m}$ into terrace deposits, basin fill, and the Pantano Formation. The highly permeable sand and gravel stream alluvium extends from the land surface to a depth of $3.4 \mathrm{~m}$, and the less permeable semiconsolidated conglomerate of the Pantano Formation extends from 3.4 to 12.5 m (fig. $6 A$ ). Electrical conductivities of the stream alluvium and the Pantano Formation ranged from about 10 to $30 \mathrm{mS} / \mathrm{m}$, and from about 25 to $45 \mathrm{mS} / \mathrm{m}$, respectively (fig. 6A). A neutron soil-moisture log was not recorded at this site.

Physical and hydraulic properties were determined for two core samples from WC4a collected at depths of 2.1 and $11.3 \mathrm{~m}$ (table 6). For the stream alluvium and the Pantano Formation, measured saturated hydraulic conductivity was $6.4 \cdot 10^{-2}$ and $4.2 \cdot 10^{-4} \mathrm{~cm} / \mathrm{s}$, respectively; porosity was 0.43 and $0.33 \mathrm{~cm}^{3} / \mathrm{cm}^{3}$, respectively; and soil-water content was 0.09 and $0.07 \mathrm{~cm}^{3} / \mathrm{cm}^{3}$, respectively.

When borehole WC4a was drilled in January 2001, a saturated interval was penetrated above the Pantano Formation at a depth of 2.0 to $3.4 \mathrm{~m}$ (fig. $8 A$ ). Sedimentchloride concentrations were lower than $8 \mathrm{mg} / \mathrm{kg}$ in the stream alluvium and generally lower than $3 \mathrm{mg} / \mathrm{kg}$ in the 
Pantano Formation (fig. 9A). Tritium activity in the stream alluvium pore water was similar to activity in present-day precipitation (between 3.4 and 3.7 TU; fig. 9A). Tritium activity was $10.1 \mathrm{TU}$ in the upper $1.7 \mathrm{~m}$ of the Pantano Formation and was between 1 and 2 TU from a depth of 6.6 to $11.1 \mathrm{~m}$. This pattern indicates that recent precipitation has likely infiltrated through the stream alluvium to the Pantano Formation. Water is infiltrating into the semiconsolidated, unsaturated Pantano Formation slowly, at a rate of about $0.9 \mathrm{~cm} / \mathrm{yr}$ (assuming an average volumetric soil-water content of $0.20 \mathrm{~cm}^{3} / \mathrm{cm}^{3}$ ). Pore water within the Pantano Formation was depleted in heavy isotopes, similar to winter precipitation (fig. 10). This could indicate that the Pantano Formation receives infiltration primarily during winter streamflows or that the existing pore water was derived from infiltration received when the climate was cooler than at present.

Temperature methods detected only one summer flow event (30 minutes in duration) at WC4a between January 2001 and December 2002 (table 8). Water levels in the saturated zone, however, rose at least six times during the summer of 2001 (fig. 8A). The lack of sediment-temperature signals may be caused by a retention basin about $260 \mathrm{~m}$ upstream from the borehole. Water-level recovery was likely the result of infiltration at the retention basin and subsequent downgradient subflow above the contact between the Pantano Formation and the stream alluvium. A recharge flux could not be calculated from the detected flow event because the water level began to rise before the onset of temperaturedetected flow in the channel.
Borehole WC3 is about $7.2 \mathrm{~km}$ downstream from the mountain front. This site is within the city limits of Sierra Vista, just downstream from an area where the banks and streambed of Woodcutters Wash have been stabilized. The site is in a reach about $8 \mathrm{~m}$ wide and incised 1.8 to $3.0 \mathrm{~m}$ into terrace deposits and basin fill. Stream alluvium in the channel bed is only a few centimeters thick. The poorly sorted sand, silt, and clay of the upper basin fill extends from the land surface to a depth of $22.6 \mathrm{~m}$ (fig. $6 B$ ). The silt and clay content of the upper basin fill is generally 30 to 60 percent. Electrical conductivity of the sediments ranged from about 25 to $60 \mathrm{mS} / \mathrm{m}$ (fig. $6 B$ ). Neutron soil-moisture counts ranged from 6,000 to 9,000 in the borehole (fig. 6B).

Physical and hydraulic properties were determined for five core samples from WC3 collected at depths of $0.9,1.5$, 8.2, 13.7, and $19.8 \mathrm{~m}$ (table 6). The measured saturated hydraulic conductivity of the basin fill ranged from $1.7 \cdot 10^{-4}$ to $9.9 \cdot 10^{-3} \mathrm{~cm} / \mathrm{s}$. Porosity ranged from 0.33 and $0.40 \mathrm{~cm}^{3} / \mathrm{cm}^{3}$, and soil-water content ranged from 0.11 to $0.19 \mathrm{~cm}^{3} / \mathrm{cm}^{3}$.

Sediment-chloride concentrations ranged from 3 to $70 \mathrm{mg} / \mathrm{kg}$ from the surface to $4.9 \mathrm{~m}$, and were below $4 \mathrm{mg} / \mathrm{kg}$ from 5.2 to $22.6 \mathrm{~m}$ (fig. $9 \mathrm{~B}$ ). Stable-isotope data indicate that the high chloride concentrations near the surface are not the result of chloride accumulation due to evapotranspiration; stable-isotope values in pore water at $0.2 \mathrm{~m}$ had evaporative signatures, but the values at $0.8 \mathrm{~m}$ and below did not (fig. 10). The high chloride concentrations in the shallow part of the unsaturated zone are probably indicative of chloride concentrations in runoff from Sierra Vista. Pore-water tritium activity values from the surface to $16.6 \mathrm{~m}$ were similar to those of present-day precipitation (between 1.0 and $6.3 \mathrm{TU}$; fig. 9B).

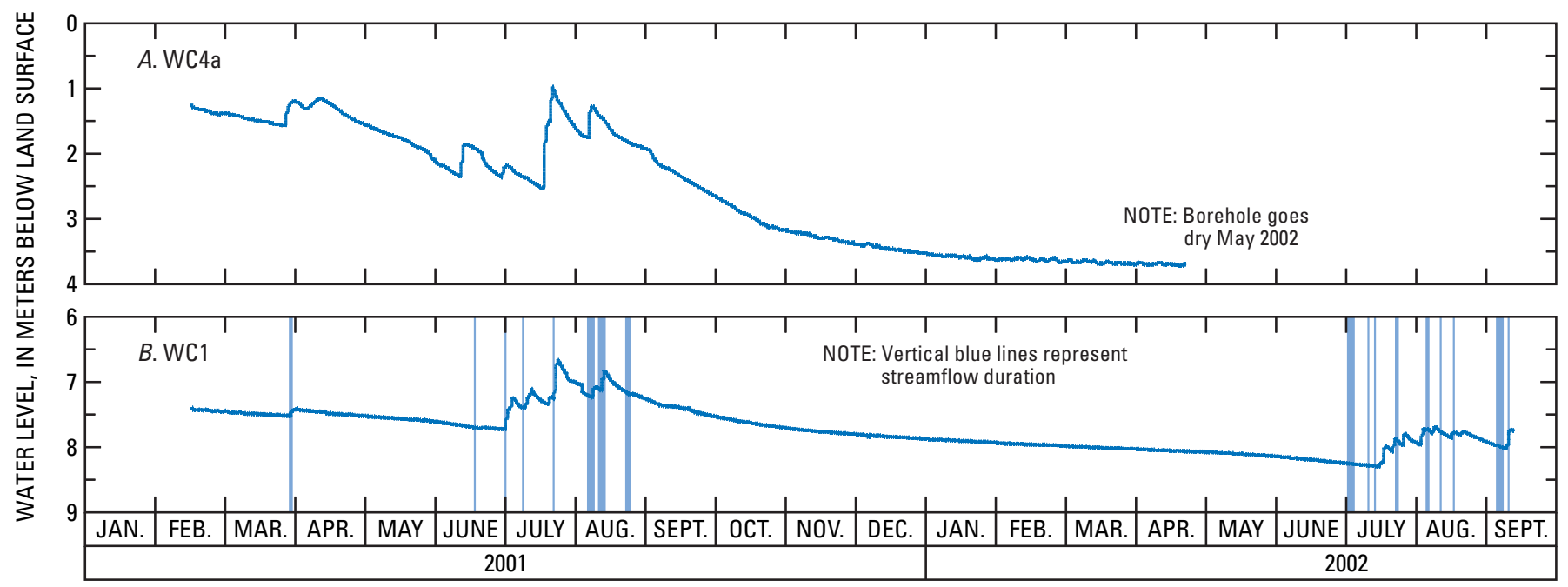

Figure 8. Water levels and streamflow durations from temperature sensors, Woodcutters Wash boreholes, Sierra Vista subwatershed, Arizona. A, WC4a; B, WC1. 
A. WC4a

TRITIUM, IN TRITIUM UNITS

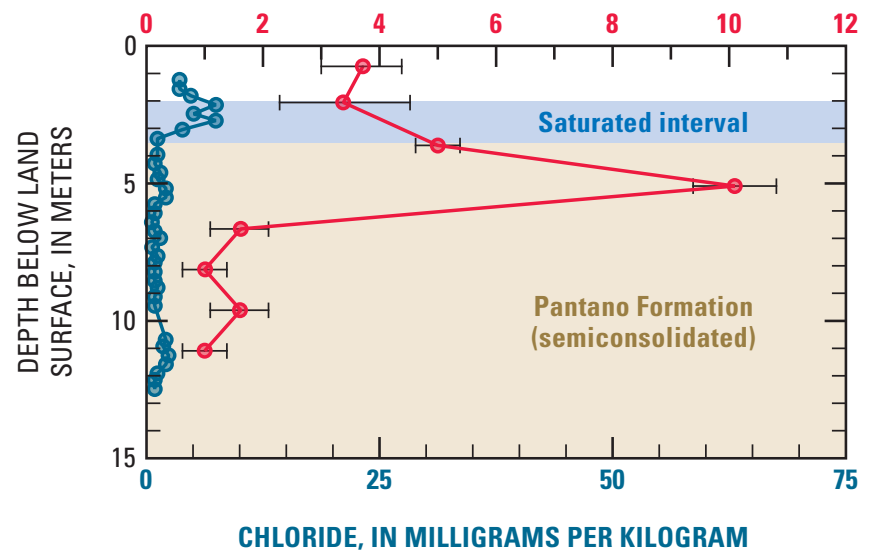

NOTE: Tritium values include standard error of estimate bars

\section{WC2}

TRITIUM, IN TRITIUM UNITS

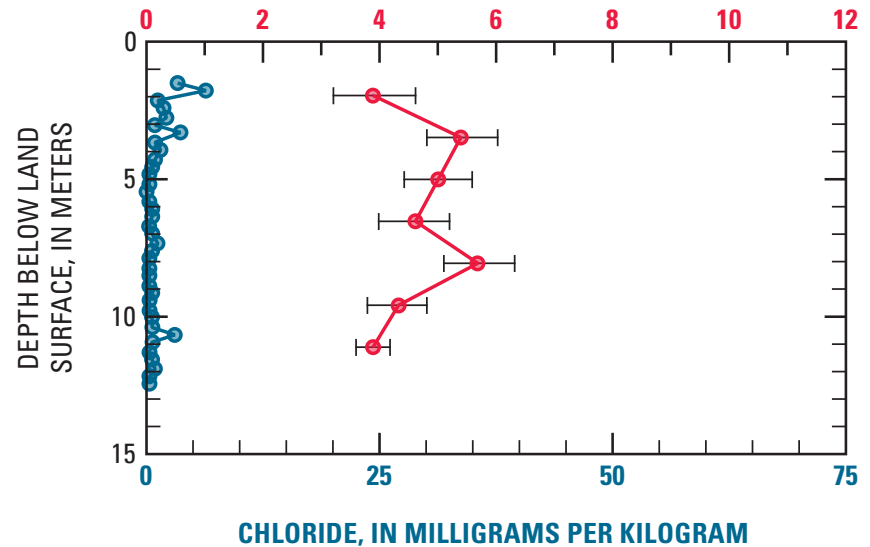

B. WC3

TRITIUM, IN TRITIUM UNITS

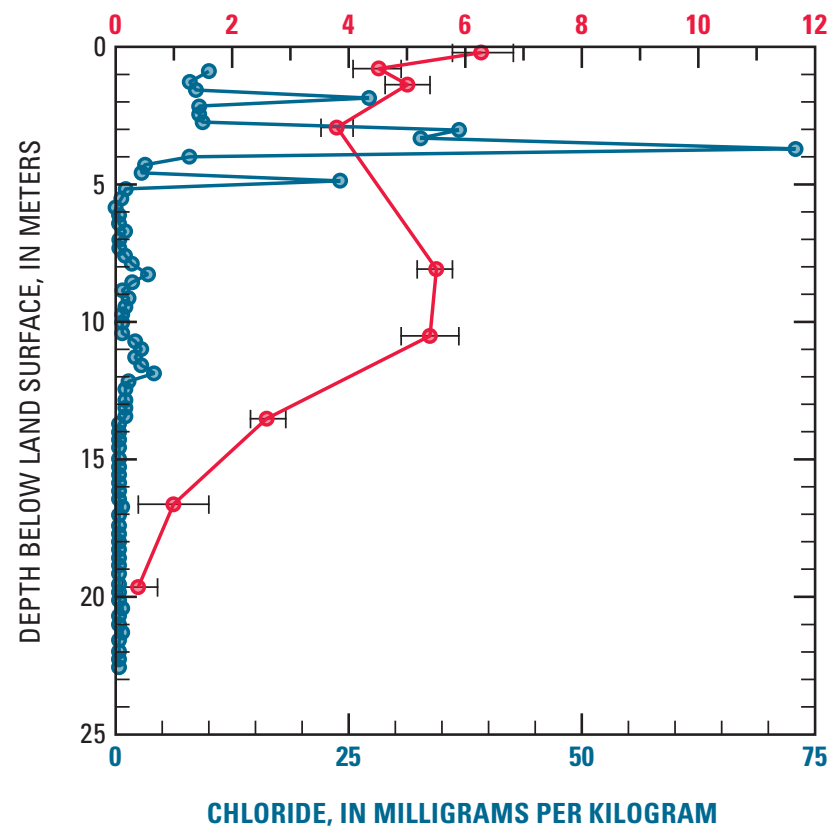

D. WC1

TRITIUM, IN TRITIUM UNITS

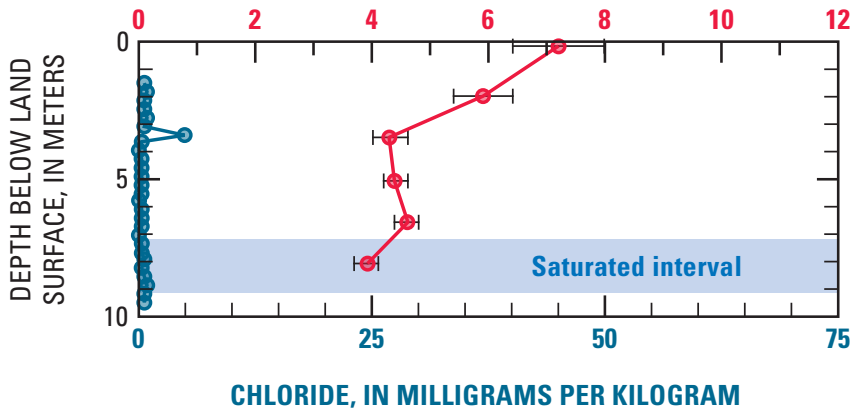

Figure 9. Sediment-chloride and pore-water tritium data, Woodcutters Wash boreholes, Sierra Vista subwatershed, Arizona. $\boldsymbol{A}$, WC4a; $\boldsymbol{B}$, WC3; $\boldsymbol{C}$, WC2; $\boldsymbol{D}$, WC1. 


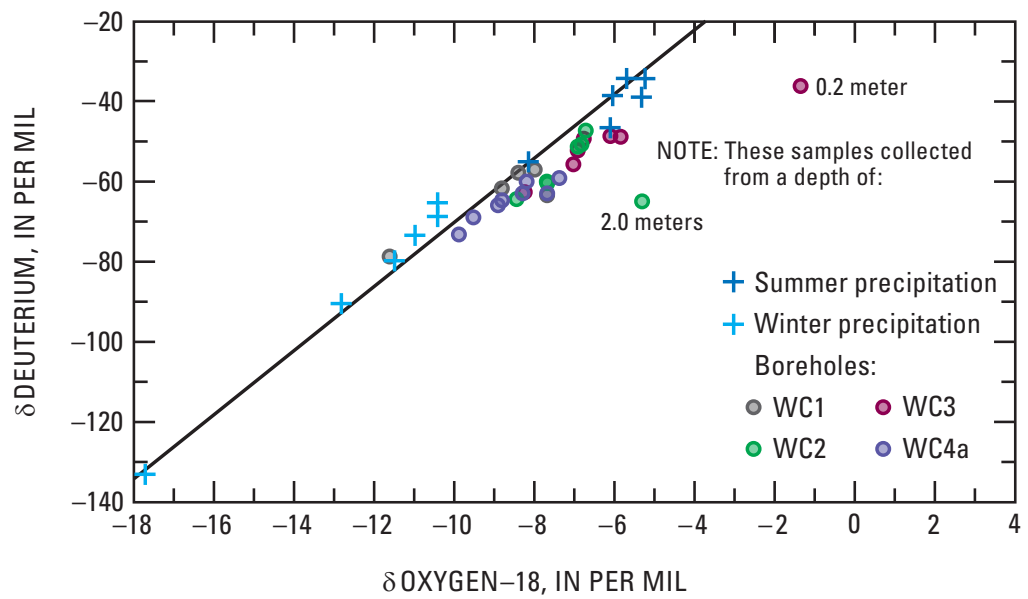

Figure 10. Stable-isotope data for pore water collected from Woodcutters Wash boreholes and for precipitation, Sierra Vista subwatershed, Arizona.

The tritium activity at $19.7 \mathrm{~m}$ was $0.4 \mathrm{TU}$. Five flow events were detected at WC3 between January 2002 and December 2002 (table 8). There were no sediment-temperature perturbations, however, at $1.5 \mathrm{~m}$ and below during or after flow events.

The temperature data indicate that the infiltration flux at WC3 is too low to perturb the sediment-temperature profile during and after individual flow events. Tritium data indicate an infiltration rate of about $4.1 \mathrm{~cm} / \mathrm{yr}$ (assuming an average volumetric soil-water content of $0.15 \mathrm{~cm}^{3} / \mathrm{cm}^{3}$ ). Stable-isotope values in pore water were between the ranges for summer and winter precipitation, indicating that infiltration may have occurred during both summer and winter streamflow events in the past (fig. 10).

Borehole WC2 is about $12.3 \mathrm{~km}$ downstream from the mountain front. The site is in a 22-m wide channel reach that is incised about $1.8 \mathrm{~m}$ into terrace deposits and basin fill. The channel bed is floored with only a veneer of stream alluvium and is underlain by less permeable, poorly sorted sand, silt, and clay of the basin fill (fig. 6C). The silt and clay content of the basin fill is generally 50 to 80 percent. Geophysical borehole logs were not recorded in this borehole.

Physical and hydraulic properties were determined for five core samples from WC2 collected at depths of 2.1, 3.7, 6.7, 8.2, and $9.8 \mathrm{~m}$ (table 6). The measured saturated hydraulic conductivity of the basin fill ranged from $9.8 \cdot 10^{-6}$ to $2.2 \cdot 10^{-2} \mathrm{~cm} / \mathrm{s}$. Porosity of the basin fill ranged from 0.34 to $0.52 \mathrm{~cm}^{3} / \mathrm{cm}^{3}$. The soil-water content of the basin fill ranged from 0.15 to $0.47 \mathrm{~cm}^{3} / \mathrm{cm}^{3}$.

Sediment-chloride concentrations to $12.5 \mathrm{~m}$ were low (less than $7 \mathrm{mg} / \mathrm{kg}$ ), and tritium activity to $11.1 \mathrm{~m}$ was comparable to that of present-day precipitation (between 3.9 and 5.7 TU), indicating that recent infiltration has occurred to at least $11.1 \mathrm{~m}$ (fig. 9C). Pore-water stable-isotope values at $2.0 \mathrm{~m}$ had a slight evaporative signature and indicate infiltration of both summer and winter streamflow (fig. 10).
This borehole was not completed with a casing; therefore, sediment-temperature data are not available and infiltration fluxes could not be determined.

Borehole WC1 is at the SPRNCA boundary $16.4 \mathrm{~km}$ downstream from the Huachuca Mountains. The site is in a reach $10 \mathrm{~m}$ wide and incised several meters into the basin fill. The highly permeable stream alluvium, consisting of sand and gravel, extends from land surface to $3.7 \mathrm{~m}$; basin fill consisting of silt and clay extends from 3.7 to $9.1 \mathrm{~m}$; and basin fill consisting of sand extends from 9.1 to $9.4 \mathrm{~m}$ (fig. 6D). The basin fill includes a large amount of calcium carbonate from 3.7 to $5.2 \mathrm{~m}$, and a slightly sandy zone from 6.4 to $7.0 \mathrm{~m}$. Electrical conductivity of the sediments was about $10 \mathrm{mS} / \mathrm{m}$ within the stream alluvium and 60 to $100 \mathrm{mS} / \mathrm{m}$ within the basin fill (fig. 6D). The higher electrical conductivity in the basin fill is likely due to both higher soil-water content and a higher silt and clay content than the stream alluvium.

Drilling of borehole WC1 in January 2001 penetrated saturated sediments at $7.5 \mathrm{~m}$. Water levels were highly variable during the monitoring period, from 6.6 to $8.3 \mathrm{~m}$ below the land surface, and rose as much as $0.5 \mathrm{~m}$ in 2 days following a single flow event (fig. 8B). Neutron soil-moisture counts ranged from 5,000 to 7,000 in the stream alluvium and 7,000 to nearly 20,000 in the basin fill (fig. 6D). The highest counts correspond to saturated or near-saturated sediments.

Physical and hydraulic properties were determined for four core samples from WC1 collected at depths of $0.3,2.1$, 3.7 , and $6.7 \mathrm{~m}$ (table 6). The measured saturated hydraulic conductivity of the stream alluvium ranged from $3.6 \cdot 10^{-2}$ to $7.2 \cdot 10^{-2} \mathrm{~cm} / \mathrm{s}$ and that of the basin fill ranged from $2.1 \cdot 10^{-6}$ to $3.2 \cdot 10^{-3} \mathrm{~cm} / \mathrm{s}$. Porosity of the stream alluvium ranged from 0.37 to $0.46 \mathrm{~cm}^{3} / \mathrm{cm}^{3}$; porosity of the basin fill was not determined. Soil-water contents of the stream alluvium ranged from 0.07 to $0.13 \mathrm{~cm}^{3} / \mathrm{cm}^{3}$, and the soilwater content at one depth in the basin fill was $0.37 \mathrm{~cm}^{3} / \mathrm{cm}^{3}$. 
Sediment-chloride concentrations to $8.8 \mathrm{~m}$ were low (less than $6 \mathrm{mg} / \mathrm{kg}$ ) and tritium activity values to $8.1 \mathrm{~m}$ were between 3.9 and 7.2 TU (fig. 9D), indicating that recent infiltration has occurred to at least $9.1 \mathrm{~m}$. Stable-isotope values in pore water were between the isotope ratio ranges for summer and winter precipitation, indicating that infiltration prior to drilling may have occurred during both summer and winter streamflow events (fig. 10). An evaporative signature is not evident in the stable-isotope data.

Eighteen flow events occurred at WC1 between January 2001 and December 2002 (tab;e 8). During four events, temperature perturbations were detected at 1.5 and $3.0 \mathrm{~m}$, but not below $3.0 \mathrm{~m}$ (table 9). The water level in the saturated zone, however, rose sharply following each event, indicating that the infiltrating streamflow is recharging the saturated zone. The lack of temperature variation below $3.0 \mathrm{~m}$, coupled with the substantial water-level response, supports the occurrence of recharge from nearby areas but not directly through the silt and clay at the site. The water-level response may represent a confined response in sandy stringers within the silt and clay that are hydraulically connected to upstream areas where infiltration occurs.

Infiltration fluxes to $3.0 \mathrm{~m}$ below the land surface during flow events ranged from 1.3 to $1.5 \mathrm{~m} / \mathrm{hr}$ (fig. 11 and tables 9 and 11). Percolation fluxes to $3.0 \mathrm{~m}$ after flow events ranged from 0.4 to $1.5 \mathrm{~m} / \mathrm{hr}$ (table 9 ).

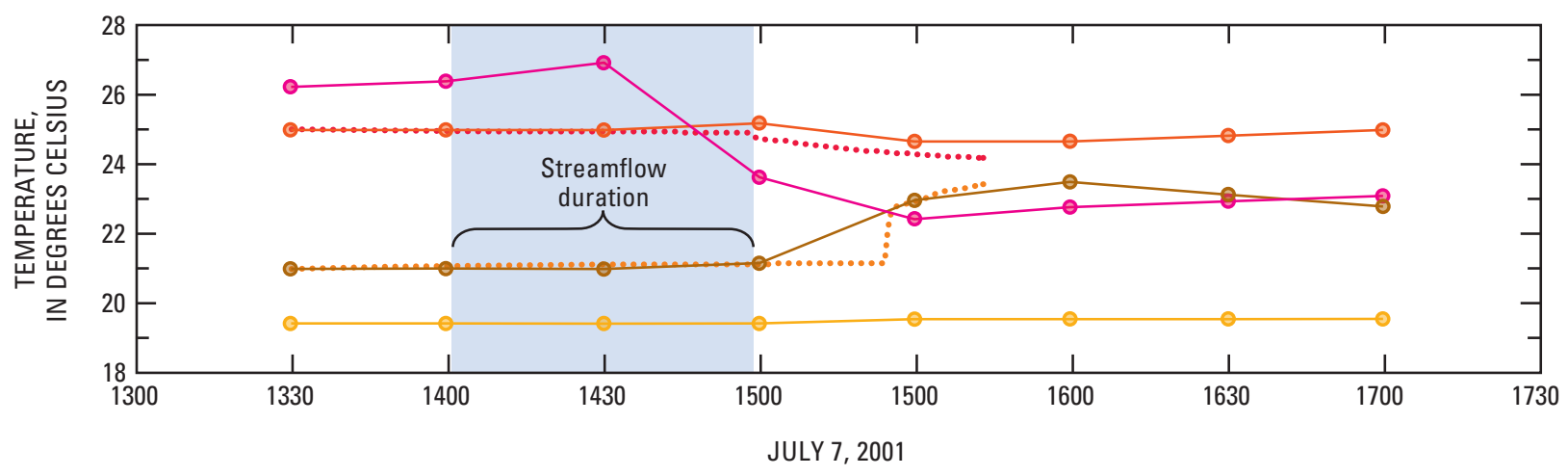

EXPLANATION

DEPTH AND SOURCE OF TEMPERATURE DATA

$\bigcirc$ O 0 METER, MEASURED

$\bigcirc \quad 1.5$ METERS, MEASURED

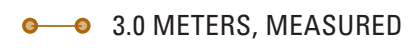

$\bigcirc$ - 4.6 METERS, MEASURED
.... 1.5 METERS, VS2DH MODEL

-... 3.0 METERS, VS2DH MODEL

Figure 11. Streamflow duration and sediment temperatures from sensors and from VS2DH model output, Woodcutters Wash borehole WC1, Sierra Vista subwatershed, July 7, 2001. 


\section{Miller Canyon Wash}

Miller Canyon Wash is a northeast-trending channel with headwaters in the Huachuca Mountains. The channel is $16.2 \mathrm{~km}$ long and has an average slope of $20.5 \mathrm{~m} / \mathrm{km}$. The channel widens from less than $1 \mathrm{~m}$ along the upper reaches to more than $4 \mathrm{~m}$ along the lower reaches. It is incised less than $1 \mathrm{~m}$ along the upper reaches and $1 \mathrm{~m}$ or more along the lower reaches. The channel drains a $32.8-\mathrm{km}^{2}$ area that ranges in elevation from 1,252 to 2,859 $\mathrm{m}$. Desert scrub, grassland, and mesquite are the primary land-cover types in the drainage basin; oak woodland and forest are dominant in the mountainous areas (fig. 2). About 15 percent of the basin, along the mountain front, is urban. The urban areas, however, generally have less paved area than the urban areas in the Woodcutters Wash drainage basin.

Soils in the drainage basin vary from loamy soils and fine paleosoils below the mountains to clayey soils downgradient. Along the stream channel, soils are sandy (fig. 3 ). The permeable stream alluvium ranges in thickness from a few centimeters near the mountains to a few meters in the lower reaches. The stream alluvium is underlain by low permeability basin fill that has variable amounts of clay, silt, sand, and gravel.

Ephemeral streamflows recorded in 2001-2002 ranged in duration from about $30 \mathrm{~min}$ to $19.8 \mathrm{hr}$ (table 8). Flows in the upper reaches were less frequent but generally were of longer duration than those farther downstream (fig. 7). The farthest upstream site, temperature sensor 377806 , detected four flows, which had an average duration of $9.1 \mathrm{~min}$. The farthest downstream site, temperature sensor 374919, detected six flows, which had an average duration of $2.8 \mathrm{hr}$.

Borehole MC2 is at the contact between the crystalline rocks of the Huachuca Mountains and the basin fill. The site is in a reach about $2 \mathrm{~m}$ wide and incised less than $1 \mathrm{~m}$ into the basin fill. Drilling penetrated a layer of predominantly poorly sorted gravel and sand of the basin fill from the land surface to $15.8 \mathrm{~m}$ that included a layer of silt and clay from 6.4 to $7.6 \mathrm{~m}$ (fig. $6 E$ ). Electrical conductivity of the sediments at $\mathrm{MC} 2$ ranged from about 20 to $40 \mathrm{mS} / \mathrm{m}$ (fig. $6 E$ ). Borehole
$\mathrm{MC} 1$ is at the SPRNCA boundary, $7.1 \mathrm{~km}$ downstream from the mountain front. The site is in a reach about $4 \mathrm{~m}$ wide and incised several meters into the basin fill. Drilling penetrated poorly sorted sand, silt, and clay of the basin fill from the land surface to $25.0 \mathrm{~m}$ (fig. $6 F$ ). Electrical conductivity of the sediments ranged from about 20 to $100 \mathrm{mS} / \mathrm{m}$ (fig. $6 F$ ). Neutron soil-moisture counts ranged from about 7,000 to 11,000 for MC2 (fig. 6E); a neutron soil-moisture log was not completed in $\mathrm{MC} 1$.

Physical and hydraulic properties of the basin fill were determined for three core samples from MC2 collected at depths of 1.8, 7.0, and $10.1 \mathrm{~m}$; and for four core samples from MC1 collected at depths of 0.9, 4.0, 8.5, and $19.2 \mathrm{~m}$ (table 6). The measured saturated hydraulic conductivity ranged from $1.7 \cdot 10^{-2}$ to $3.2 \cdot 10^{-6} \mathrm{~cm} / \mathrm{s}$ at $\mathrm{MC} 2$ and from $9.3 \cdot 10^{-3}$ to $1.8 \cdot 10^{-6} \mathrm{~cm} / \mathrm{s}$ at $\mathrm{MC} 1$. Porosities ranged from 0.36 to $0.42 \mathrm{~cm}^{3} / \mathrm{cm}^{3}$ at MC2 and from 0.36 to $0.39 \mathrm{~cm}^{3} / \mathrm{cm}^{3}$ at $\mathrm{MC} 1$. Soil-water contents ranged from 0.18 to $0.30 \mathrm{~cm}^{3} / \mathrm{cm}^{3}$ at $\mathrm{MC} 2$ and from 0.28 to $0.31 \mathrm{~cm}^{3} / \mathrm{cm}^{3}$ at $\mathrm{MC} 1$.

Sediment-chloride concentrations were lower than $5 \mathrm{mg} / \mathrm{kg}$ in the upper $15.8 \mathrm{~m}$ of MC2 and in the upper $21.9 \mathrm{~m}$ of MC1. Tritium activity in the upper $9.9 \mathrm{~m}$ of MC2 and in the upper $22.1 \mathrm{~m}$ of $\mathrm{MC} 1$ were comparable to activity in present-day precipitation (1.9 to $7.8 \mathrm{TU}$; fig 12). Recent infiltration has occurred to at least $9.9 \mathrm{~m}$ at $\mathrm{MC} 2$ and $22.1 \mathrm{~m}$ at MC1. Stable-isotope values for the pore water at both sites indicated that infiltration occurred during summer and winter; pore water below $0.2 \mathrm{~m}$ did not show evaporative signatures (fig. 13).

One streamflow event, 18 hours in duration, was detected between January 2002 and December 2002 at MC2; streamflow was not detected between April 2002 and December 2002 at MC1 (table 8). There were no sedimenttemperature perturbations at or below $1.5 \mathrm{~m}$ during or after the flow event at MC2. The temperature data suggest that the infiltration flux at $\mathrm{MC} 2$ is too low to perturb the sedimenttemperature profile during and after individual events. Infiltration fluxes could not be calculated from sedimenttemperature profiles at either site because of a lack of data. 
A. MC2

TRITIUM, IN TRITIUM UNITS

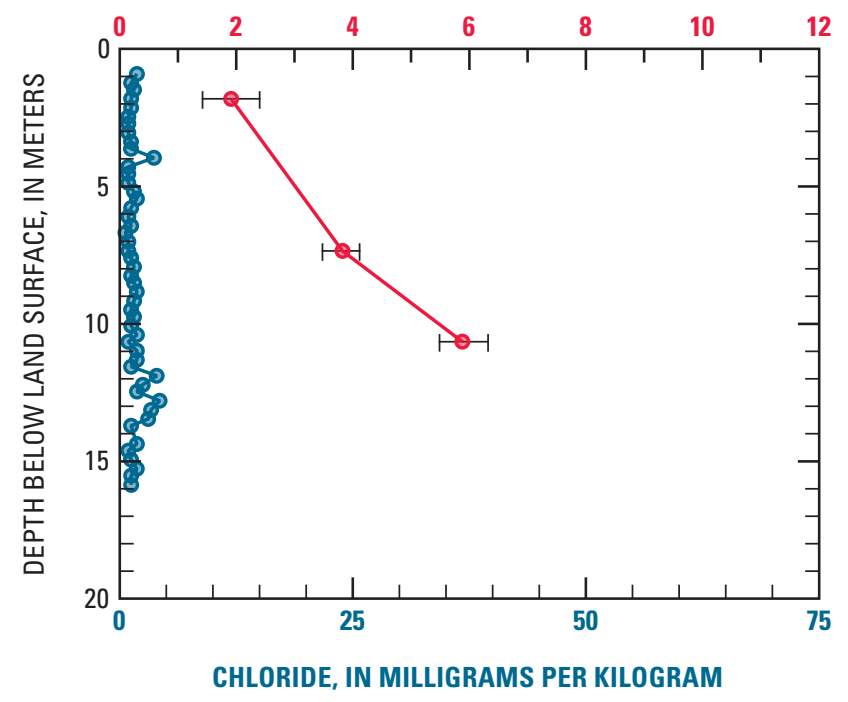

NOTE: Tritium values include standard error of estimate bars
B. MC1

TRITIUM, IN TRITIUM UNITS

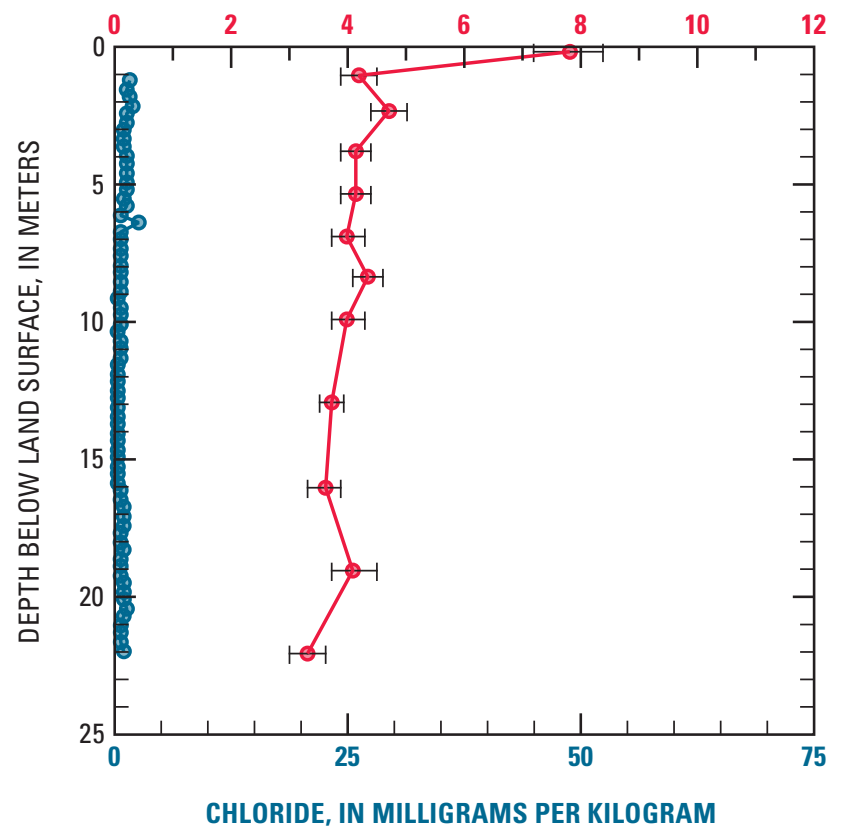

Figure 12. Sediment-chloride and pore-water tritium data, Miller Canyon Wash boreholes, Sierra Vista subwatershed, Arizona. $A, \mathrm{MC2} ; \boldsymbol{B}, \mathrm{MC1}$.

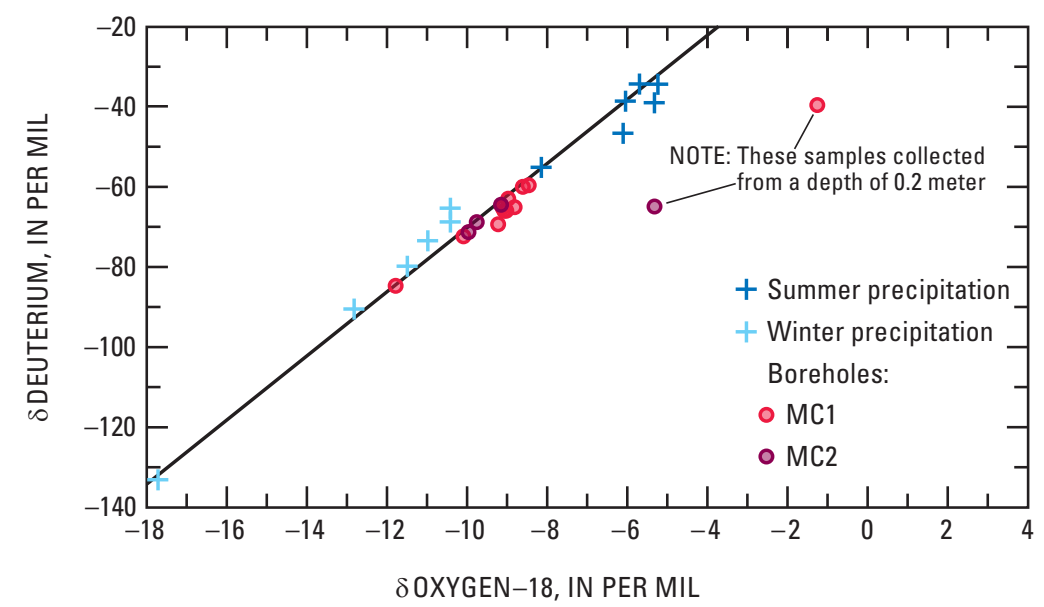

Figure 13. Stable-isotope data for pore water collected from Miller Canyon Wash boreholes and for precipitation, Sierra Vista subwatershed, Arizona. 


\section{Walnut Gulch}

Walnut Gulch is a west-trending channel with headwaters in the Tombstone Hills and the Mule and Dragoon Mountains. The main channel is about $26.5 \mathrm{~km}$ long and has an average slope of $12.1 \mathrm{~m} / \mathrm{km}$. The channel widens from less than $2 \mathrm{~m}$ along the upper reaches to more than $40 \mathrm{~m}$ along the lower reaches. It is incised less than $1 \mathrm{~m}$ along the upper reaches and $4 \mathrm{~m}$ or more along the lower reaches. The channel drains a $152.1-\mathrm{km}^{2}$ area that ranges in elevation from 1,164 to $1,939 \mathrm{~m}$. Desert scrub, grassland, and mesquite are the primary landcover types in the drainage basin (fig. 2). Approximately 3 percent of the Walnut Gulch Basin, near the northern extent of the Tombstone Hills, is urbanized.

Soils in the drainage basin vary from clayey near the mountains to secondarily developed calcium carbonate downgradient; soils are sandy along the stream channel (fig. 3). The permeable stream alluvium ranges in thickness from about $1 \mathrm{~m}$ near the mountains to $15 \mathrm{~m}$ in the lower reaches of the channel. The stream alluvium is underlain by low-permeability consolidated to semiconsolidated conglomerate of the lower basin fill near the mountains and by upper basin fill in the lower reaches of the channel.

The ARS has monitored ephemeral streamflows in Walnut Gulch since the 1950s by using a series of flumes. Ephemeral streamflows recorded during 2001-2002 at flumes 1, 6, and 11 ranged in duration from $12 \mathrm{~min}$ to $82.2 \mathrm{hr}$ (table 8). Flows generally were more frequent and of longer duration near the mountain front than in areas downgradient (fig. 7). The farthest upstream site, flume 11, had 12 flows, which had an average duration of $11.1 \mathrm{hr}$. The farthest downstream site, flume 1, had eight flows, which had an average duration of $3.2 \mathrm{hr}$.

Borehole WG3 is just upstream from flume 11 and is $7.2 \mathrm{~km}$ downstream from the mountain front. The site is in a reach about $2 \mathrm{~m}$ wide and incised less than $1 \mathrm{~m}$ into the basin fill. Drilling penetrated unconsolidated stream alluvium of sand and gravel to $1.8 \mathrm{~m}$, and semiconsolidated conglomerate of the lower basin fill from 1.8 to $13.1 \mathrm{~m}$ (fig. $6 G$ ). The electrical conductivity of the conglomerate was about 5 to $10 \mathrm{mS} / \mathrm{m}$ (fig. $6 G$ ). A neutron soil-moisture $\log$ was not recorded in this borehole. The high degree of induration of the conglomerate and basalt prevented the collection of cores below $1.8 \mathrm{~m}$, and physical and hydraulic properties were not determined for the stream alluvium above $1.8 \mathrm{~m}$.

Sediment-chloride concentrations were less than $4 \mathrm{mg} / \mathrm{kg}$ in the upper $1.8 \mathrm{~m}$, and tritium activity in the upper $0.8 \mathrm{~m}$ was comparable to activity for present-day precipitation (6.5 to $8.5 \mathrm{TU}$; fig. 14A), indicating that recent infiltration has occurred to at least $0.8 \mathrm{~m}$. Although the primary porosity of the semiconsolidated conglomerate is small, infiltration can occur through secondary fractures. The stable-isotope values of the pore water at 0.2 and $0.8 \mathrm{~m}$ had a strong evaporative signature (fig. 15). Sediment temperatures were not monitored at this site, and therefore, infiltration fluxes were not calculated.
A. WG3

TRITIUM, IN TRITIUM UNITS

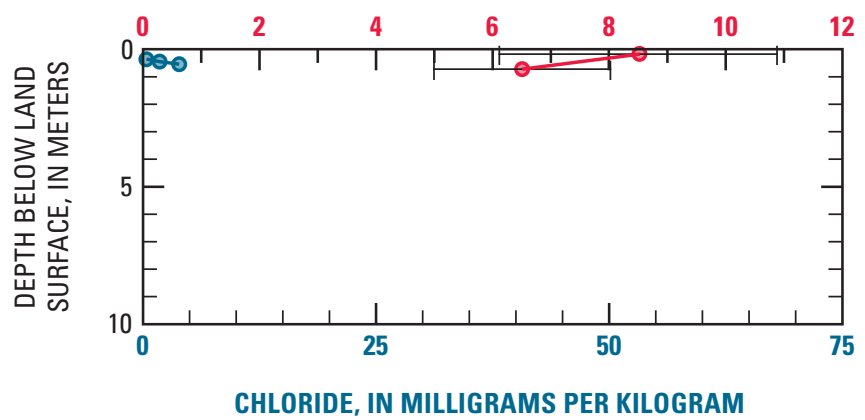

B. WG2

TRITIUM, IN TRITIUM UNITS

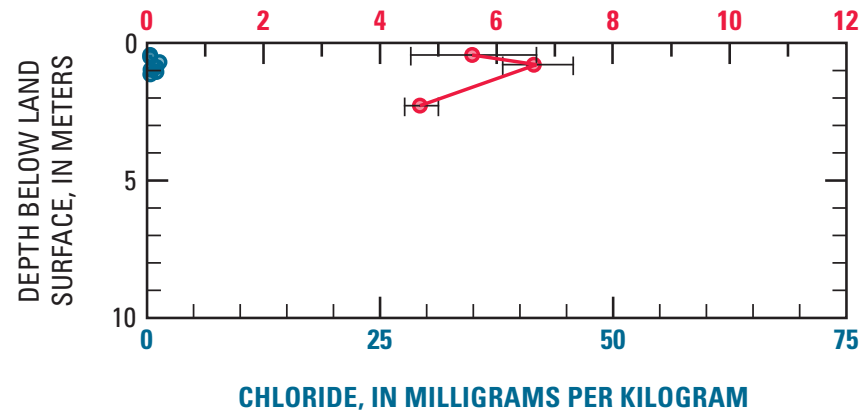

C. WG1

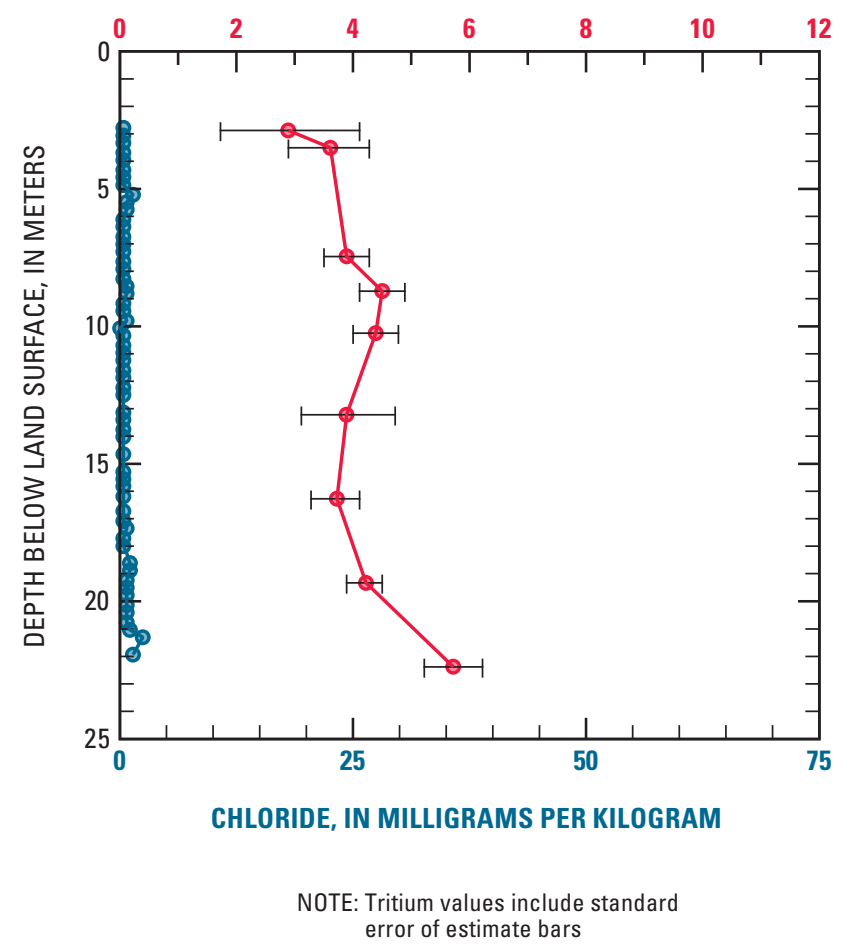

Figure 14. Sediment-chloride and pore-water tritium data, Walnut Gulch boreholes, Sierra Vista subwatershed, Arizona. $A, W G 3 ; B, W G 2 ; C, W G 1$. 


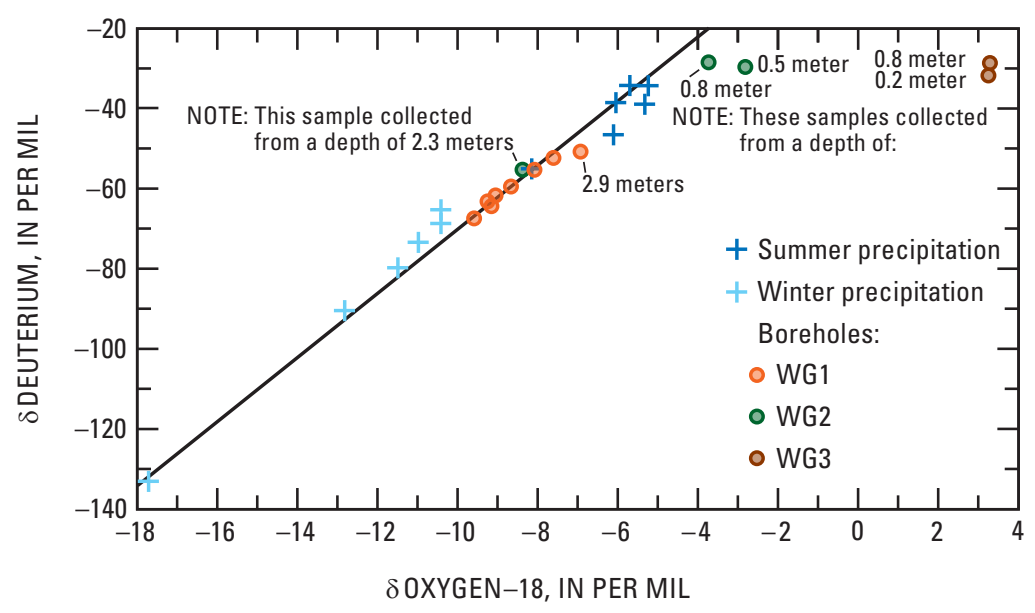

Figure 15. Stable-isotope data for pore water collected from Walnut Gulch boreholes and for precipitation, Sierra Vista subwatershed, Arizona.

Borehole WG2 is just upstream from flume 6 and is $13.2 \mathrm{~km}$ downstream from the mountain front. The site is in a reach about $13 \mathrm{~m}$ wide and incised several meters into the basin fill. Drilling penetrated unconsolidated stream alluvium of sand and gravel to $3.7 \mathrm{~m}$, semiconsolidated conglomerate of the lower basin fill from 3.7 to $11.6 \mathrm{~m}$, and basalt from 11.6 to $12.2 \mathrm{~m}$ (fig. $6 H$ ). Electrical conductivity of the sediments was less than $5 \mathrm{mS} / \mathrm{m}$ in the stream alluvium and from 10 to $15 \mathrm{mS} / \mathrm{m}$ in the conglomerate (fig. $6 H$ ). Neutron soil-moisture counts in the borehole ranged from about 6,000 to 10,000 .

As at WG3, the high degree of induration of the conglomerate and basalt prevented the collection of cores below $3.7 \mathrm{~m}$, and physical and hydraulic properties were not determined for the stream alluvium above $3.7 \mathrm{~m}$.

Sediment-chloride concentrations in the upper $3.4 \mathrm{~m}$ were less than the detection limit of $1.80 \mathrm{mg} / \mathrm{kg}$, and tritium activity in the upper $2.3 \mathrm{~m}$ was comparable to values for present-day precipitation ( 4.7 to $6.7 \mathrm{TU}$; fig. $14 \mathrm{~B}$ ), indicating that recent infiltration has occurred to at least $2.3 \mathrm{~m}$. The stable-isotope values for the pore water at 0.5 and $0.8 \mathrm{~m} \mathrm{had}$ a strong evaporative signature; however, the pore water at $2.3 \mathrm{~m}$ did not (fig. 15). Although the primary porosity of the consolidated conglomerate is small, infiltration can occur through secondary fractures.

Seven flow events occurred at flume 6 between May 2002 and December 2002 (table 8). Borehole WG2 was damaged sometime after mid-July 2002, and therefore only sediment temperatures from the flow on July 19, 2002, can be used to determine infiltration fluxes at this site. During this flow, a temperature perturbation was detected at a depth of $3.0 \mathrm{~m}$ (table 9). The temperature sensor at $1.5 \mathrm{~m}$ malfunctioned during this time and all data were lost. The calculated infiltration fluxes to $3.0 \mathrm{~m}$ during flow ranged from 0.4 to $1.0 \mathrm{~m} / \mathrm{hr}$ (fig. $16 \mathrm{~A}$ and tables 9 and 11).
Borehole WG1 is just upstream from flume 1 and $25.6 \mathrm{~km}$ downstream from the mountain front. The site is in a reach about $31 \mathrm{~m}$ wide and incised several meters into the basin fill. Drilling penetrated stream alluvium of sand and gravel in the upper $14.5 \mathrm{~m}$ underlain by basin fill that is 20 to 55 percent silt and clay (fig. $6 I$ ). Electrical conductivity of the sediments ranged from less than $20 \mathrm{mS} / \mathrm{m}$ within the stream alluvium to 25 to $65 \mathrm{mS} / \mathrm{m}$ within the basin fill (fig. $6 I$ ). A neutron soil-moisture log was not recorded in this borehole. Physical and hydraulic properties were determined for four core samples from WG1 collected at depths of 3.0, 3.7, 13.4 , and $22.6 \mathrm{~m}$ (table 6 ). The data indicate little variation of properties between the stream alluvium and the upper basin fill. The measured saturated hydraulic conductivity of the cores ranged from $2.0 \cdot 10^{-2}$ to $4.6 \cdot 10^{-2} \mathrm{~cm} / \mathrm{s}$; porosity ranged from 0.35 to $0.47 \mathrm{~cm}^{3} / \mathrm{cm}^{3}$; and soil-water content ranged from 0.10 to $0.25 \mathrm{~cm}^{3} / \mathrm{cm}^{3}$.

Sediment-chloride concentrations in the upper $22.3 \mathrm{~m}$ were less than $3 \mathrm{mg} / \mathrm{kg}$, and tritium activity in the upper $22.4 \mathrm{~m}$ was comparable to present-day precipitation (2.9 to 4.5 TU; fig. 14C), indicating that recent infiltration has occurred to at least $22.4 \mathrm{~m}$. Stable-isotope values at $2.9 \mathrm{~m}$ had a slight evaporative signature (fig. 15) and also indicated that water in the unsaturated zone infiltrated during both summer and winter streamflow events.

Three flow events occurred at flume 1 between April 2002 and December 2002 (table 8). All were during the summer and had durations from 12 min to about $10 \mathrm{hr}$. During each event, sediment-temperature perturbations in WG1 were detected at 1.5, 3.0, and $4.6 \mathrm{~m}$ (table 9). Temperature perturbations were detected at $6.1 \mathrm{~m}$ after the end of each flow event (table 9), but no perturbations were detected below $6.1 \mathrm{~m}$. 
A. WG2, July 19, 2002

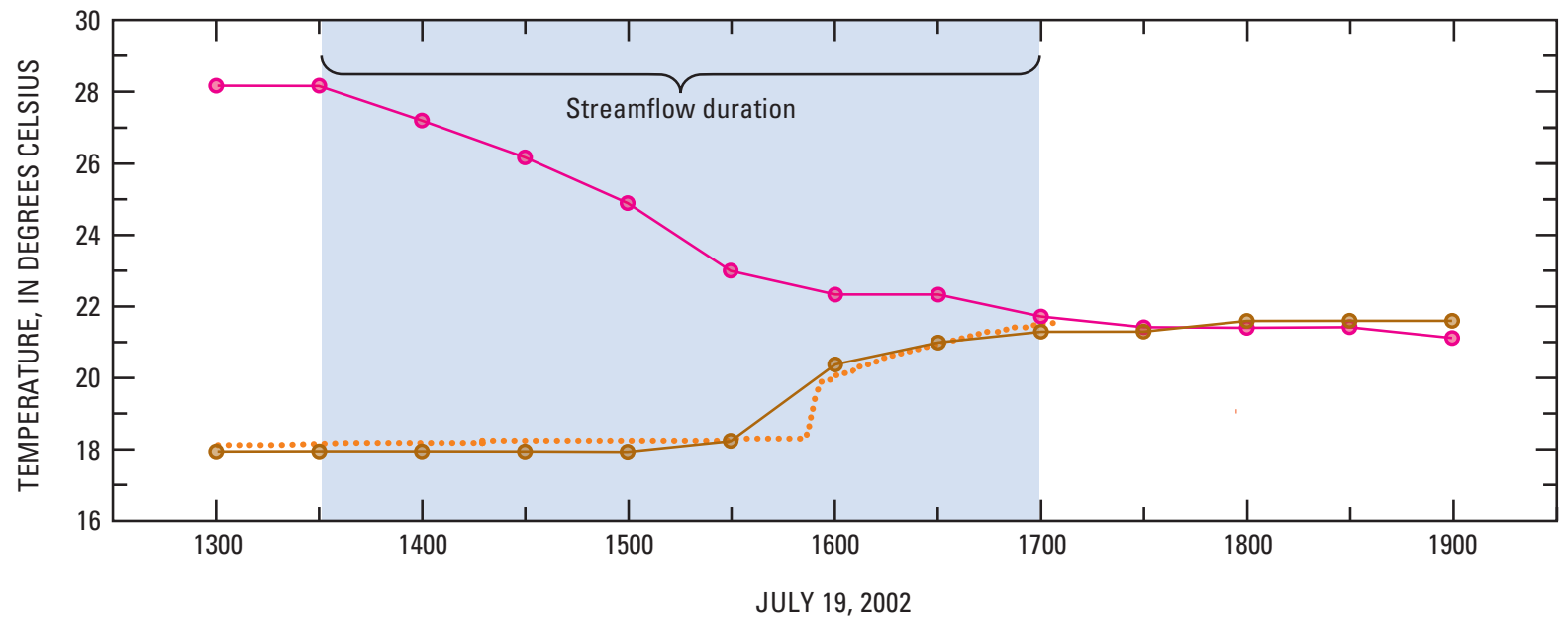

B. WG1, July $26-27,2002$

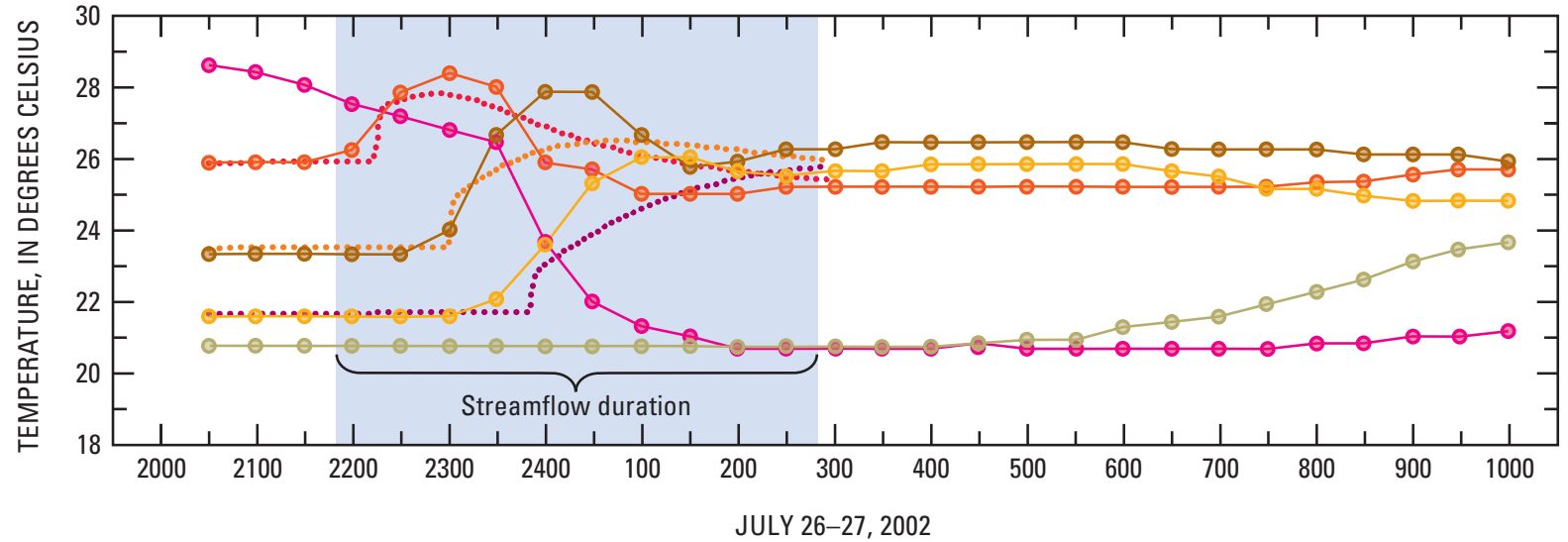

C. WG1, August 4, 2002

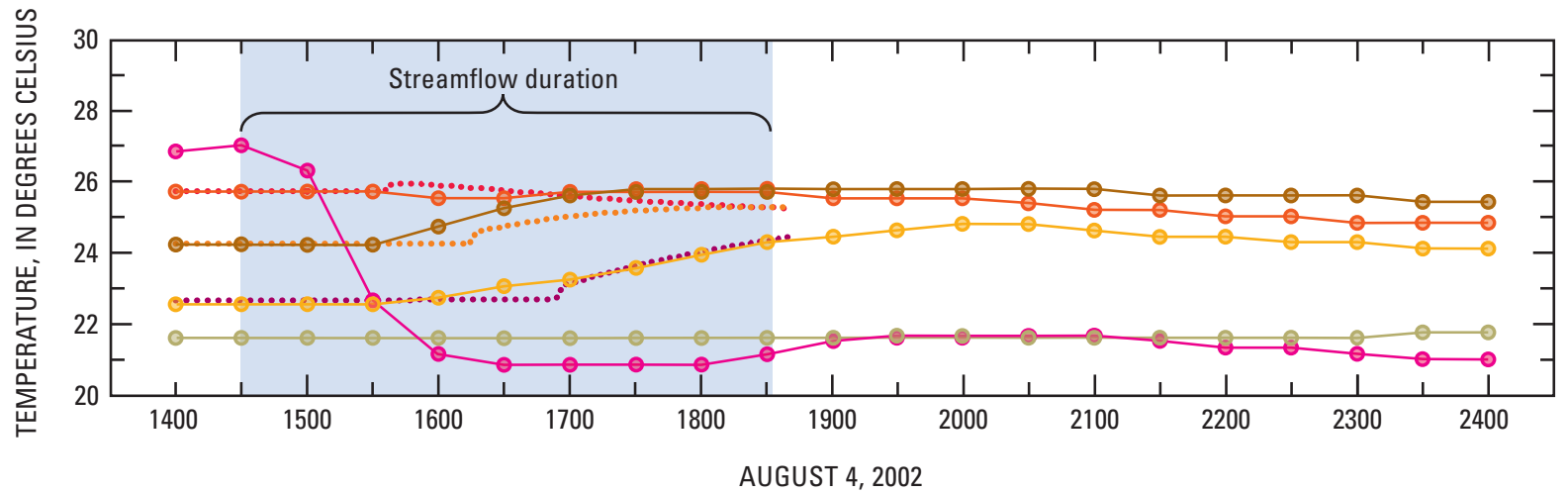

EXPLANATION

DEPTH AND SOURCE OF TEMPERATURE DATA

- 0 METER, MEASURED

$\circ \quad 1.5$ METERS, MEASURED

$\bigcirc \quad 3.0$ METERS, MEASURED $\bigcirc \quad 4.6$ METERS, MEASURED

$\circ \quad 6.1$ METERS, MEASURED
.... 1.5 METERS, VS2DH MODEL

.... 3.0 METERS, VS2DH MODEL

.... 4.6 METERS, VS2DH MODEL

Figure 16. Streamflow durations and sediment temperatures from sensors and from VS2DH model output, Walnut Gulch boreholes, Sierra Vista subwatershed, Arizona. A, WG2, July 19, 2002; B, WG1, July 26-27, 2002; C, WG1, August 4, 2002. 
Calculated infiltration fluxes to $4.6 \mathrm{~m}$ below the land surface during flow events ranged from 0.4 to $2.1 \mathrm{~m} / \mathrm{hr}$ (figs. $15 B$ and $15 C$ and tables 9 and 11). Percolation fluxes to $6.1 \mathrm{~m}$ after flow ended ranged from 0.1 to $1.0 \mathrm{~m} / \mathrm{hr}$ (table 9 ).

\section{Banning Creek}

Banning Creek is a west-trending channel with headwaters in the Mule Mountains. The channel is $8.6 \mathrm{~km}$ long and has an average slope of $15.6 \mathrm{~m} / \mathrm{km}$. The creek drains a $41.3-\mathrm{km}^{2}$ area that ranges in elevation from 1,257 to 2,217 m. Desert scrub, grassland, and mesquite are the primary land-cover types in the drainage basin; oak woodland dominates the mountainous areas (fig. 2). Less than 1 percent of the basin is urbanized land.

Soils in the drainage basin vary from lithic rock near the mountains to calcium carbonate downgradient; soils are sandy along the stream channel (fig. 3). The permeable stream alluvium ranges in thickness from less than $1 \mathrm{~m}$ near the mountains to more than $7 \mathrm{~m}$ in the lower reaches of the creek. The stream alluvium is underlain by limestone in the upper reaches and unconsolidated basin fill of clay, silt, sand, and gravel in the lower reaches.

Ephemeral streamflows recorded during 2001-2002 ranged in duration from $1 \mathrm{hr}$ to 48 days (table 8). Flows in the upper reaches were not more frequent but were of a longer duration than flows farther downstream (fig. 7). The farthest upstream streamflow-gaging station, 09470700, and temperature sensor, 377822, detected two flows during 2001-2002. The flows had an average duration of 42.9 days. The farthest downstream temperature sensor, at site $\mathrm{BC} 1$, detected eight flows, which had with an average duration of $4.6 \mathrm{hr}$.

Borehole $\mathrm{BC} 1$ is $3.9 \mathrm{~km}$ downstream from the crystalline rocks of the Mule Mountains. The channel at the site is about $4 \mathrm{~m}$ wide and is incised several meters into the basin fill.
Drilling penetrated unconsolidated stream alluvium of clay, silt, sand, and gravel from the land surface to $6.4 \mathrm{~m}$ (fig. $6 \mathrm{~J}$ ). Basin fill, which includes greater amounts of clay and silt than the stream alluvium, was penetrated from 6.4 to $25.9 \mathrm{~m}$. Electrical conductivity ranged from 10 to $50 \mathrm{mS} / \mathrm{m}$ in the stream alluvium and from 10 to $70 \mathrm{mS} / \mathrm{m}$ in the basin fill (fig. $6 J$ ). Neutron soil-moisture counts ranged from 6,000 to 10,000 in the borehole (fig. 6J).

Physical and hydraulic properties were determined for six core samples from BC1 collected at depths of 2.1, 5.2, $8.2,14.3,15.8$, and $20.4 \mathrm{~m}$ (table 6 ). The measured saturated hydraulic conductivity ranged from $9.6 \cdot 10^{-3}$ to $1.2 \cdot 10^{-1} \mathrm{~cm} / \mathrm{s}$ for the stream alluvium and from $4.1 \cdot 10^{-7}$ to $8.9 \cdot 10^{-3} \mathrm{~cm} / \mathrm{s}$ for the basin fill. Porosity of the two units ranged from 0.25 to $0.43 \mathrm{~cm}^{3} / \mathrm{cm}^{3}$, and soil-water content ranged from 0.08 to $0.29 \mathrm{~cm}^{3} 3 / \mathrm{cm}^{3}$.

Sediment-chloride concentrations in the upper $25.9 \mathrm{~m}$ were less than $12 \mathrm{mg} / \mathrm{kg}$, and tritium activity in the upper $23.3 \mathrm{~m}$ were comparable to values for present-day precipitation (3.2 to $6.7 \mathrm{TU}$; fig. 17), indicating that recent infiltration has occurred to at least $23.3 \mathrm{~m}$. Stable-isotope values for pore water were between bulk precipitation ranges for summer and winter (fig. 18), indicating that infiltration occurs during summer and winter streamflow events.

Eight flow events occurred at BC1 between January 2001 and December 2002 (table 8). During seven of the events, temperature perturbations were detected at 1.5 and $3.0 \mathrm{~m}$; temperature perturbations were also detected at 4.6 and $6.1 \mathrm{~m}$ after the end of each event (table 9).

Calculated infiltration fluxes to $3.0 \mathrm{~m}$ during flow events ranged from 0.4 to $2.8 \mathrm{~m} / \mathrm{hr}$ (fig. 19 and tables 9 and 11). Percolation fluxes to $6.1 \mathrm{~m}$ after flow ended ranged from 0.7 to $2.8 \mathrm{~m} / \mathrm{hr}$ (tables 9 and 11 ). 
TRITIUM, IN TRITIUM UNITS

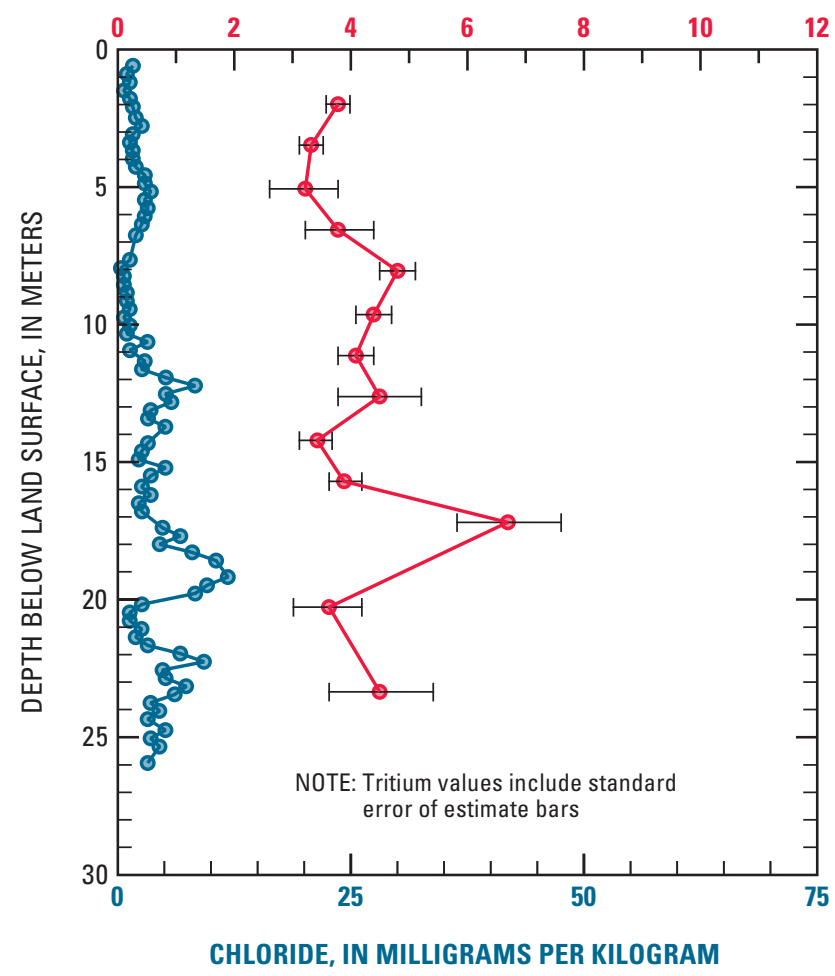

Figure 17. Sediment-chloride and pore-water tritium data, Banning Creek borehole BC1, Sierra Vista subwatershed, Arizona.

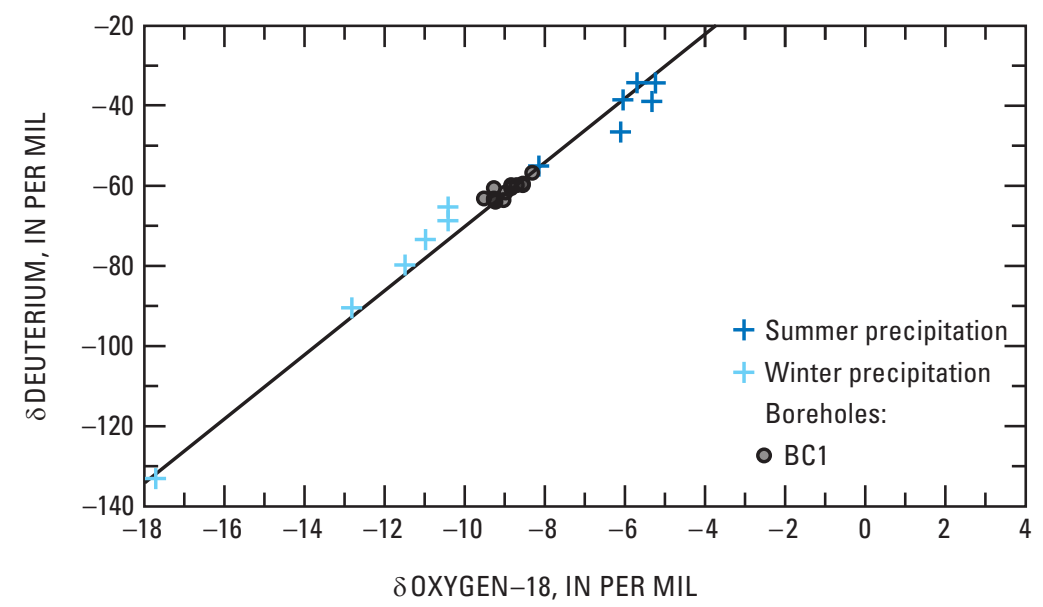

Figure 18. Stable-isotope data for pore water collected from Banning Creek borehole BC1 and for precipitation, Sierra Vista subwatershed, Arizona. 
A. July 20, 2001

Streamflow duration

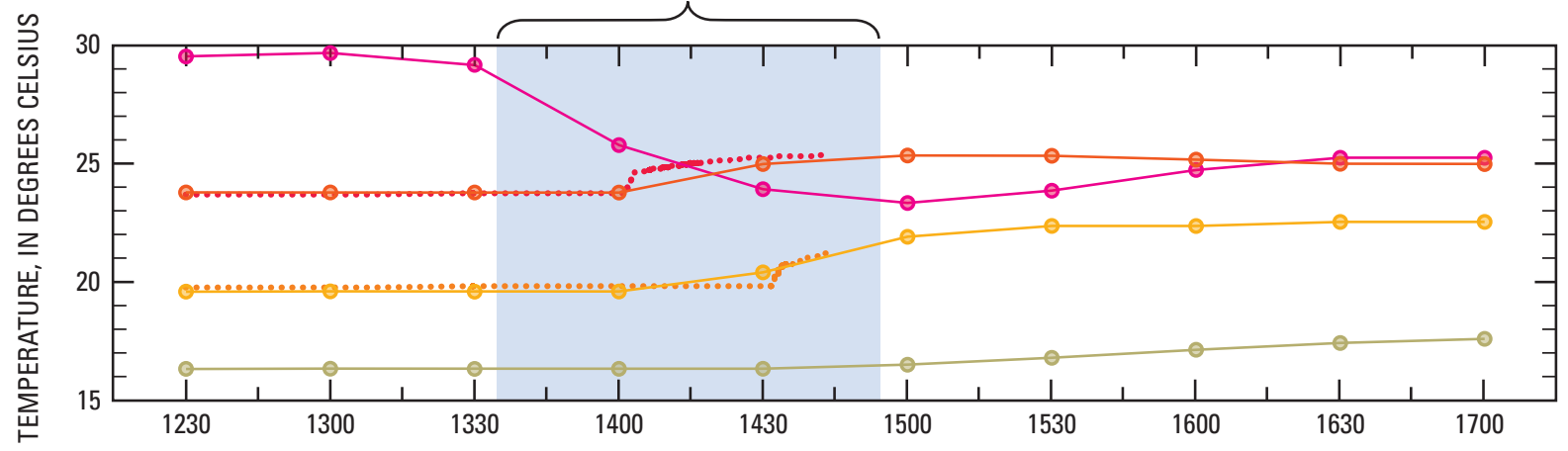

JULY 20, 2001

B. July 25, $2001 \quad$ Streamflow duration

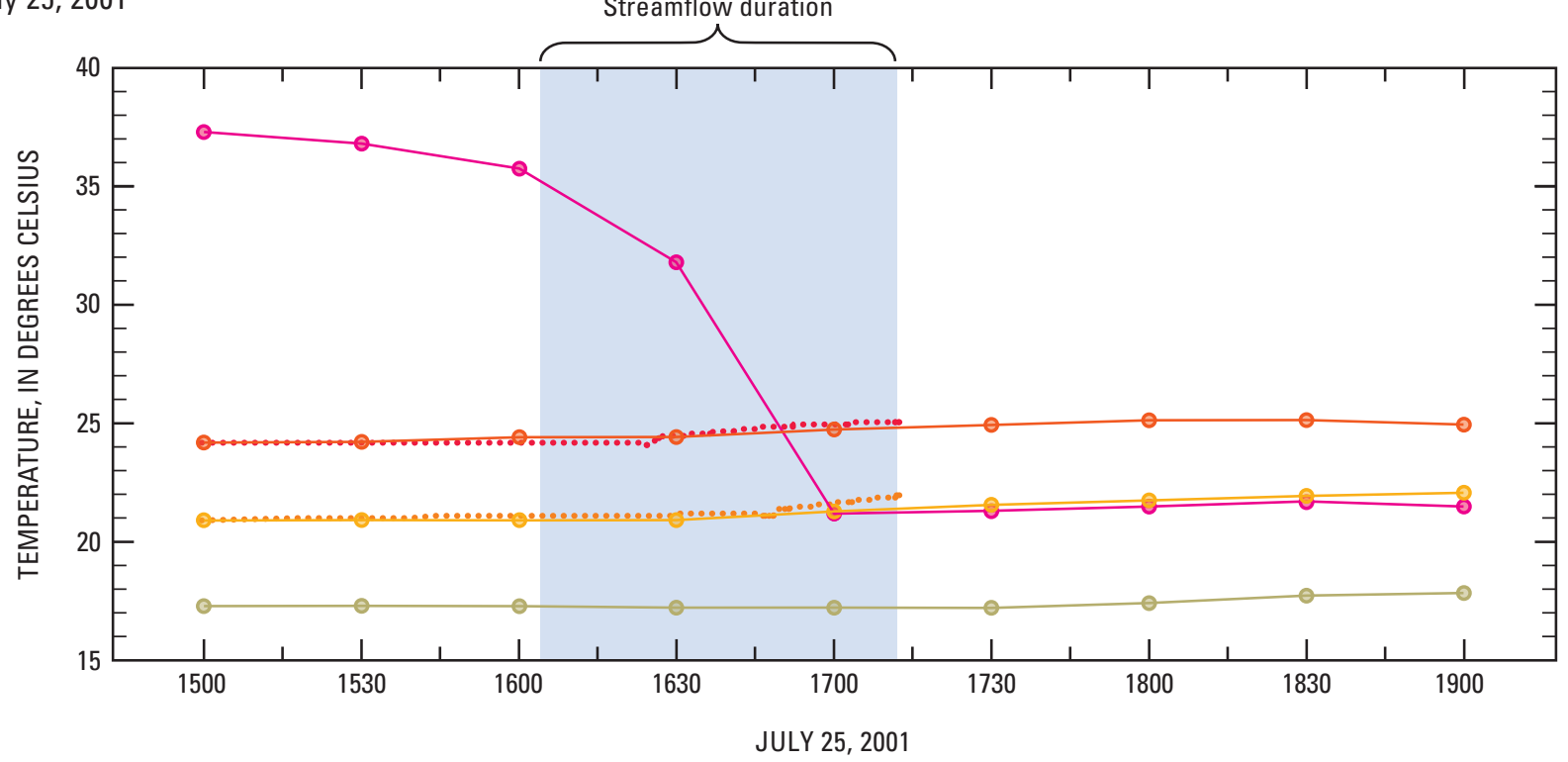

C. July 31-August 1, 2001

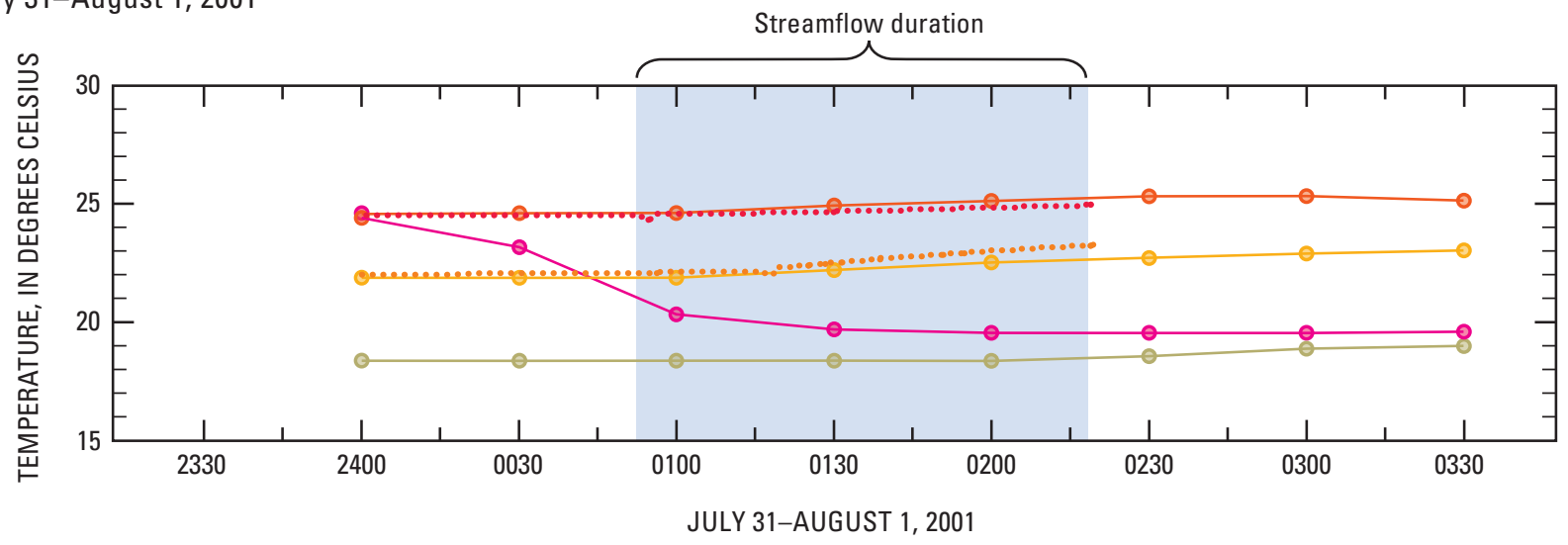

EXPLANATION

DEPTH AND SOURCE OF TEMPERATURE DATA

$\bigcirc 0$ METER, MEASURED

$\multimap 1.5$ METERS, MEASURED $\longrightarrow 3.0$ METERS, MEASURED

$\bigcirc 4.6$ METERS, MEASURED
..... 1.5 METERS, VS2DH MODEL

.... 3.0 METERS, VS2DH MODEL

Figure 19. Streamflow durations and sediment temperatures from sensors and from VS2DH model output, Banning Creek borehole BC1, Sierra Vista subwatershed, Arizona. A, July 20, 2001; B, July 25, 2001; C, August 1, 2001. 


\section{Greenbush Draw}

Greenbush Draw is a northwest-trending channel with headwaters in the Mule Mountains and in parts of Mexico. The main channel is $19.5 \mathrm{~km}$ long and has an average slope of $8.8 \mathrm{~m} / \mathrm{km}$. The channel widens from less than $2 \mathrm{~m}$ along the upper reaches to more than $14 \mathrm{~m}$ along the lower reaches of the draw. It is incised $2 \mathrm{~m}$ or more along the lower reaches. The draw drains a $306.3-\mathrm{km}^{2}$ area that ranges in elevation from 1,280 to $2,258 \mathrm{~m}$. Grassland, mesquite, and desert scrub are the primary land-cover types in the drainage basin (fig. 2). About 4 percent of the basin is urbanized land.

Soils in the drainage basin are primarily sandy along the stream channels and clayey and calcium carbonate elsewhere (fig. 3). Secondary calcium carbonate soils dominate the lower downgradient areas to the north of Greenbush Draw, and clayey soils dominate the downgradient areas to the south of Greenbush Draw. The stream alluvium ranges in thickness from $2 \mathrm{~m}$ or less in the upper reaches to $10 \mathrm{~m}$ along the lower reaches and is underlain by unconsolidated to semiconsolidated upper basin fill that includes interbedded sand, gravel, silt, and clay.

Ephemeral streamflows recorded during 2001-2002 ranged in duration from $30 \mathrm{~min}$ to $19 \mathrm{hr}$ (table 8 ). Flows in the upper reaches of Greenbush Draw were not more frequent or of a longer duration than flows at sites farther downstream (fig. 7). The farthest upstream temperature sensor, 377815, detected five flows in 2001 and 2002, which had an average duration of $7.5 \mathrm{hr}$. The farthest downstream temperature sensor, 377820, detected six flows, which had an average duration of $10.0 \mathrm{hr}$.

Borehole GD2 is $5.6 \mathrm{~km}$ downstream from the limestone and crystalline rocks of the mountains. The channel at the site is about $2 \mathrm{~m}$ wide and is incised less than $1 \mathrm{~m}$ into the basin fill. Drilling penetrated unconsolidated stream alluvium of clay, silt, sand, and gravel from the surface to $2.0 \mathrm{~m}$ and basin fill from 2.0 to $25.0 \mathrm{~m}$ (fig. $6 K$ ). The basin fill has greater percentages of clay and silt than the stream alluvium. Electrical conductivity of the sediments ranged from 10 to $70 \mathrm{mS} / \mathrm{m}$ in the stream alluvium and from 10 to $100 \mathrm{mS} / \mathrm{m}$ in the basin fill (fig. $6 K$ ). Thin saturated intervals (less than $1.2 \mathrm{~m}$ in thickness) were penetrated at depths of $8.2,12.8$, and $24.1 \mathrm{~m}$ during drilling. A neutron log was not recorded in this borehole.

Physical and hydraulic properties were determined for three core samples from GD2 collected at depths of 2.4, 5.3, and $13.1 \mathrm{~m}$ (table 6). All the cores were from basin fill. The saturated hydraulic conductivity ranged from $5.9 \cdot 10^{-3}$ to $5.3 \cdot 10^{-2} \mathrm{~cm} / \mathrm{s}$. Porosity ranged from 0.41 to $0.53 \mathrm{~cm}^{3} / \mathrm{cm}^{3}$, and soil-water content ranged from 0.14 to $0.44 \mathrm{~cm}^{3} / \mathrm{cm}^{3}$.

Sediment chloride concentrations in the upper $25.0 \mathrm{~m}$ were less than $3 \mathrm{mg} / \mathrm{kg}$, and tritium activity in the upper $19.1 \mathrm{~m}$ was similar to values for present-day precipitation (3.5 to 4.3 TU;fig. 20A), indicating that recent infiltration has occurred to at least $19.1 \mathrm{~m}$. Stable-isotope values for pore water were between ranges for summer and winter precipitation (fig. 21), indicating that infiltration occurs during summer and winter streamflow events.
TRITIUM, IN TRITIUM UNITS

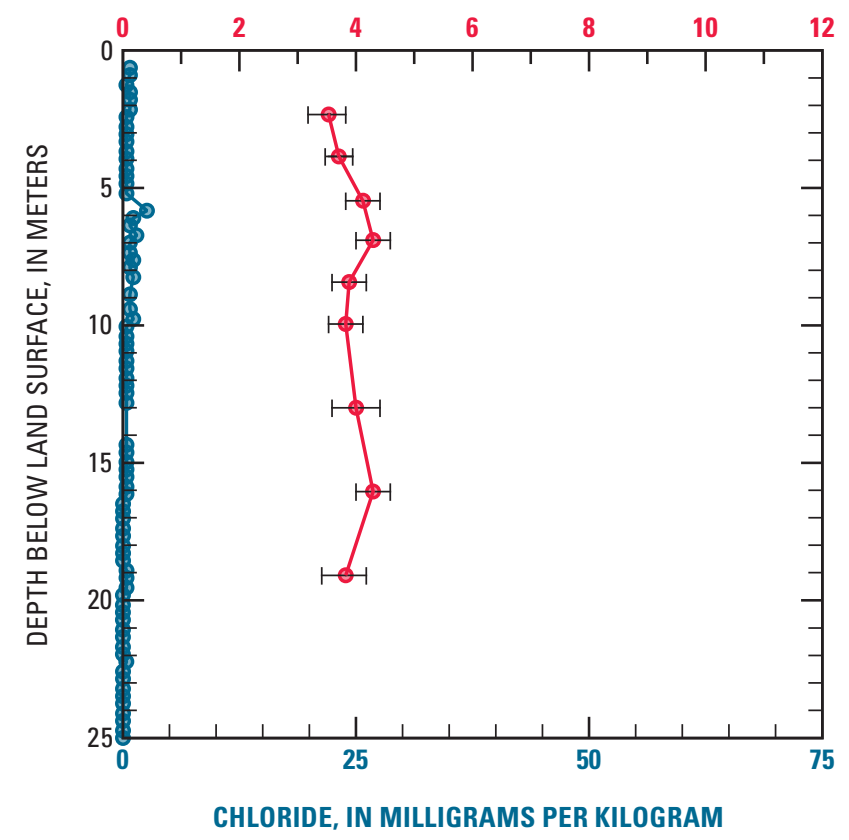

B. GD1

TRITIUM, IN TRITIUM UNITS

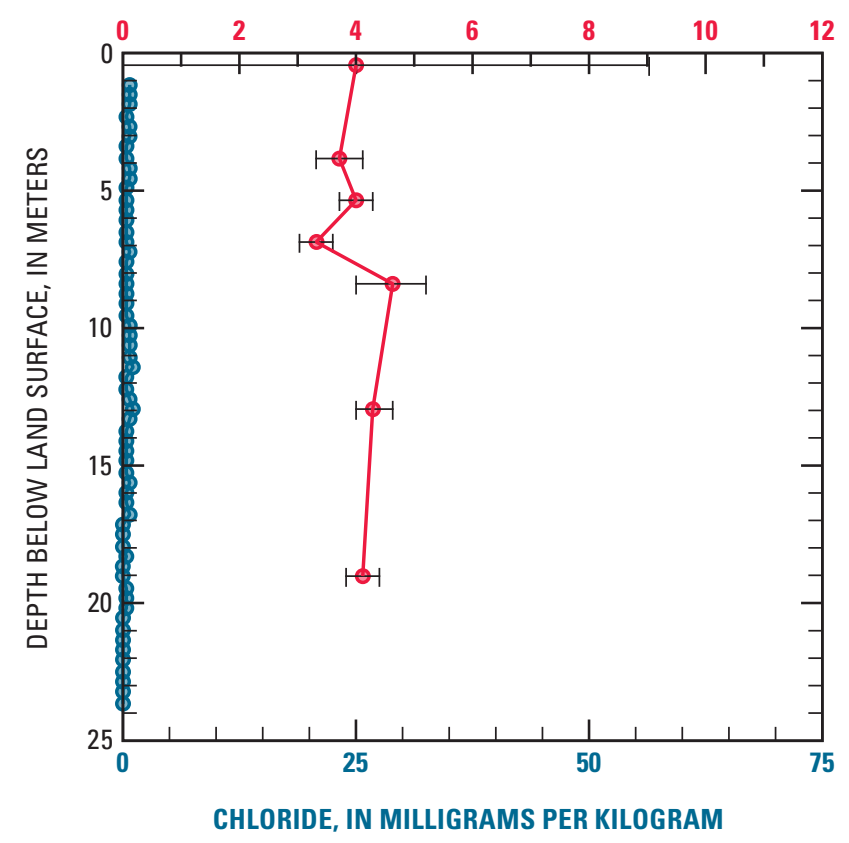

NOTE: Tritium values include standard error of estimate bars

Figure 20. Sediment-chloride and pore-water tritium data, Greenbush Draw boreholes, Sierra Vista subwatershed, Arizona. $A, \mathrm{GD} 2 ; \boldsymbol{B}, \mathrm{GD} 1$. 


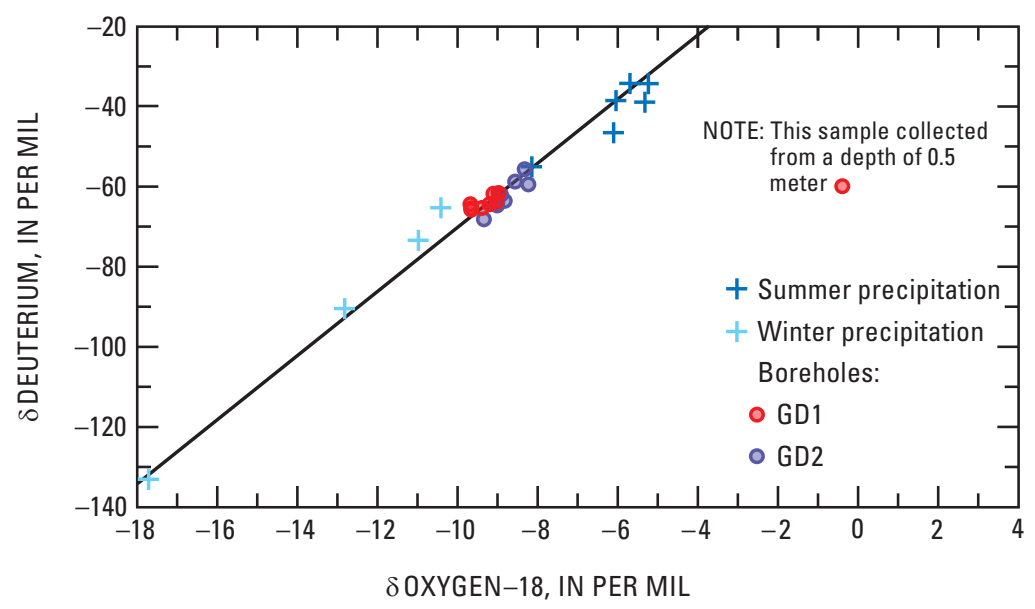

Figure 21. Stable-isotope data for pore water collected from Greenbush Draw boreholes and for precipitation.

Three flow events occurred at GD2 between January 2002 and December 2002 (table 8). Temperature perturbations were detected at 1.5, 3.0, 6.1, 9.1, and $12.2 \mathrm{~m}$ after flow ended (table 9). Calculated percolation fluxes after flow ended ranged from 0.3 to $1.8 \mathrm{~m} / \mathrm{hr}$ (table 9 .)

Borehole GD1 is $12.4 \mathrm{~km}$ downstream from the limestone and crystalline rocks of the mountains. The channel at the site is about $14 \mathrm{~m}$ wide and is incised several meters into the basin fill. Drilling penetrated unconsolidated stream alluvium of clay, silt, sand, and gravel from the land surface to $10.0 \mathrm{~m}$ and basin fill from 10.0 to $19.5 \mathrm{~m}$ (fig. $6 L$ ). The basin fill has a greater percentage of clay and silt than the stream alluvium and includes a large amount of calcium carbonate from 10.1 to $10.4 \mathrm{~m}$. Electrical conductivity of the sediments ranged from 10 to $20 \mathrm{mS} / \mathrm{m}$ in the stream alluvium and from 15 to $100 \mathrm{mS} / \mathrm{m}$ in the basin fill (fig. $6 L$ ). Neutron counts did not vary greatly $(7,000$ to 12,000$)$ in the borehole (fig. $6 L$ ).

Physical and hydraulic properties were determined for four core samples from GD1 collected at depths of 4.0, 7.0, and $13.1 \mathrm{~m}$ (table 6). The measured saturated hydraulic conductivity ranged from $4.6 \cdot 10^{-3}$ to $1.4 \cdot 10^{-2} \mathrm{~cm} / \mathrm{s}$ for the stream alluvium and was $6.8 \cdot 10^{-8} \mathrm{~cm} / \mathrm{s}$ for the basin fill. Porosity was determined only for one core, from the stream alluvium, and was $0.27 \mathrm{~cm}^{3} / \mathrm{cm}^{3}$. Soil-water content was determined only for the stream alluvium, and ranged from 0.11 to $0.15 \mathrm{~cm}^{3} / \mathrm{cm}^{3}$.

Sediment-chloride concentrations in the upper $18.9 \mathrm{~m}$ were less than the detection limit of $1.80 \mathrm{mg} / \mathrm{kg}$, and tritium activity in the upper $19.1 \mathrm{~m}$ was similar to values for presentday precipitation (3.3 to $4.6 \mathrm{TU}$; fig. $20 \mathrm{~B}$ ), indicating that recent infiltration has occurred to at least $19.1 \mathrm{~m}$. Stable-isotope values for pore water at $0.5 \mathrm{~m}$ had strong evaporative signatures; the remaining values were between bulk precipitation ranges for summer and winter (fig. 21), indicating that infiltration occurs during summer and winter streamflow events.

One flow event was detected at GD1 between May 2002 and December 2002 (table 8). Temperature perturbations, at depths of 1.5, 3.0, 6.1, and $9.1 \mathrm{~m}$, were detected only after flow ended (table 9). Percolation fluxes to $9.1 \mathrm{~m}$ after flow ended ranged from 0.1 to $0.8 \mathrm{~m} / \mathrm{hr}$ (table 9 ).

\section{Basin-Floor Infiltration}

Infiltration fluxes were determined for basin-floor sites in the Walnut Gulch, Carr Canyon Wash, and Woodcutters Wash drainage basins. Data used in the determination of infiltration fluxes included physical and hydraulic properties of sediments, chloride concentrations of sediments, and pore-water stable-isotope values and tritium activity. Where possible, infiltration fluxes through the upper 4.0 to $9.8 \mathrm{~m}$ of sediments were estimated.

Borehole WG4 is within the Walnut Gulch drainage basin on a hilltop in the ARS Lucky Hills research station. Mesquite woodland is the primary land-cover type at the site (fig. 2). Basin fill penetrated by the borehole consists of semiconsolidated to unconsolidated sand and gravel from the surface to $3.4 \mathrm{~m}$, consolidated clay and silt from 3.4 to $5.5 \mathrm{~m}$, semiconsolidated to unconsolidated sand and gravel from 5.5 to $9.8 \mathrm{~m}$, and semiconsolidated to consolidated clay, silt, and sand from 9.8 to $13.4 \mathrm{~m}$ (fig. $6 M$ ). Electrical conductivity of the sediments ranged from 0 to $30 \mathrm{mS} / \mathrm{m}$ (fig. $6 M$ ). A neutron soil-moisture log was not recorded in this borehole. 
Physical and hydraulic properties were determined for two core samples collected at depths of 4.3 and $13.4 \mathrm{~m}$ in the borehole (table 6 ). Saturated hydraulic conductivity was $1.3 \cdot 10^{-2}$ and $1.7 \cdot 10^{-2} \mathrm{~cm} / \mathrm{s}$. Porosity was 0.48 and $0.50 \mathrm{~cm}^{3} / \mathrm{cm}^{3}$, and soil-water content was 0.10 and $0.19 \mathrm{~cm}^{3} / \mathrm{cm}^{3}$.

Sediment-chloride concentrations increased sharply to $226 \mathrm{mg} / \mathrm{kg}$ from 1.5 to $2.1 \mathrm{~m}$ as a result of evapotranspirative enrichment (fig. 22A). Concentrations then decreased sharply to $34 \mathrm{mg} / \mathrm{kg}$ from 2.4 to $3.4 \mathrm{~m}$, probably as a result of no downward water movement or preferential transport past the root zone. Below $3.4 \mathrm{~m}$, the chloride concentration ranged from 3 to $90 \mathrm{mg} / \mathrm{kg}$. Chloride below $2.1 \mathrm{~m}$ likely was emplaced by infiltration during a wetter period.

Tritium activity of the pore water indicates that water has infiltrated to at least $7.5 \mathrm{~m}$ since 1952 (fig. 22A). No anthropogenic tritium was detected at $13.3 \mathrm{~m}$. The location of the tritium peak at $2.0 \mathrm{~m}$ indicates an infiltration flux of about $1.0 \mathrm{~cm} / \mathrm{yr}$ (assuming an average volumetric soil-water content of $0.19 \mathrm{~cm}^{3} / \mathrm{cm}^{3}$ ) to $2.0 \mathrm{~m}$. The chloride data indicate that about 694 years is required for water to infiltrate to this depth, at a flux of about $0.2 \mathrm{~cm} / \mathrm{yr}$ (fig. 22B). Deeper penetration of tritium relative to that of chloride was previously identified in desert soils; possible explanations have included the downward movement of tritium in the vapor phase (Phillips and others, 1988; Scanlon, 1991) and the downward preferential flow of tritium through cracks and macropores (Izbicki and others, 2000).

Pore-water stable-isotope values to $13.3 \mathrm{~m}$ plot along an evaporative trend line that has a slope of 2.5 (fig. 23). The point of intersection between the evaporative trend line and the meteoric water line indicates that historical infiltration at WG4 was similar isotopically to recent winter precipitation.

\section{A. Chloride and tritium}

\section{TRITIUM, IN TRITIUM UNITS}

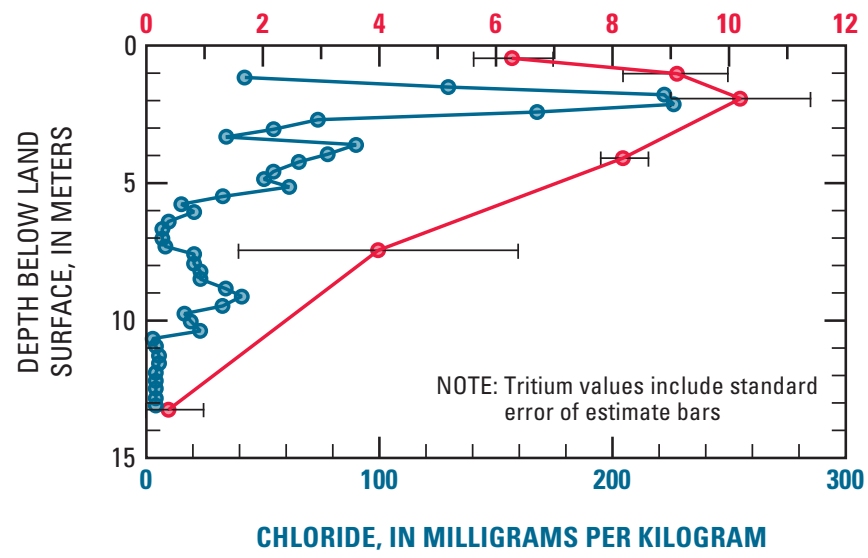

The chloride, tritium, and stable-isotope data indicate that little to no recent infiltration has occurred past shallow depths at site WG4.

Borehole WG5 also is within the Walnut Gulch drainage basin. The borehole is on a hilltop within the ARS Kendall research station. Grassland is the primary land-cover type at the site (fig. 2). Drilling penetrated consolidated basinfill conglomerate from the surface to $12.2 \mathrm{~m}$ (fig. $6 \mathrm{~N}$ ). The electrical conductivity ranged from 10 to $20 \mathrm{mS} / \mathrm{m}$ (fig. $6 N$ ). A neutron soil-moisture log was not recorded in this borehole. The degree of consolidation of the sediments precluded collection of complete cores; therefore, physical and hydraulic properties of the conglomerate were not determined.

Sediment-chloride concentrations were not measured at this site. Stable-isotope values of pore water at $0.2 \mathrm{~m}$ showed a slight evaporative signature, but were not as enriched as at similar depths at other basin-floor sites (fig. 23). The tritium activity of pore water at $0.2 \mathrm{~m}$ was $0.4 \mathrm{TU}$. These isotopic dataindicate that recent infiltration at this site has not extended past shallow depths.

Borehole BF1 is within the Carr Canyon drainage basin on a flat area of the basin floor between the Carr Canyon and Ramsey Canyon Washes. Vegetation at the site is sparse and the primary land-cover types are mesquite woodland and grassland (fig. 2). Drilling penetrated two primary lithologic layers within the basin fill: unconsolidated sand and gravel from the surface to about $8 \mathrm{~m}$; and semiconsolidated clay, silt, sand, and gravel from $8 \mathrm{~m}$ to $15.8 \mathrm{~m}$ (fig. 6O). The electrical conductivity of the sediments were about 15 to $25 \mathrm{mS} / \mathrm{m}$ from the surface to $11 \mathrm{~m}$, and about 30 to $60 \mathrm{mS} / \mathrm{m}$ from 11 to $15.8 \mathrm{~m}$. The higher values below $11 \mathrm{~m}$ are indicative of a higher soil-water content or higher silt and clay content below $11 \mathrm{~m}$ (fig. 6O). A neutron soil-moisture log was not recorded in this borehole.

\section{$B$. Residence time and infiltration flux}

\section{INFILTRATION FLUX, IN CENTIMETERS PER YEAR}

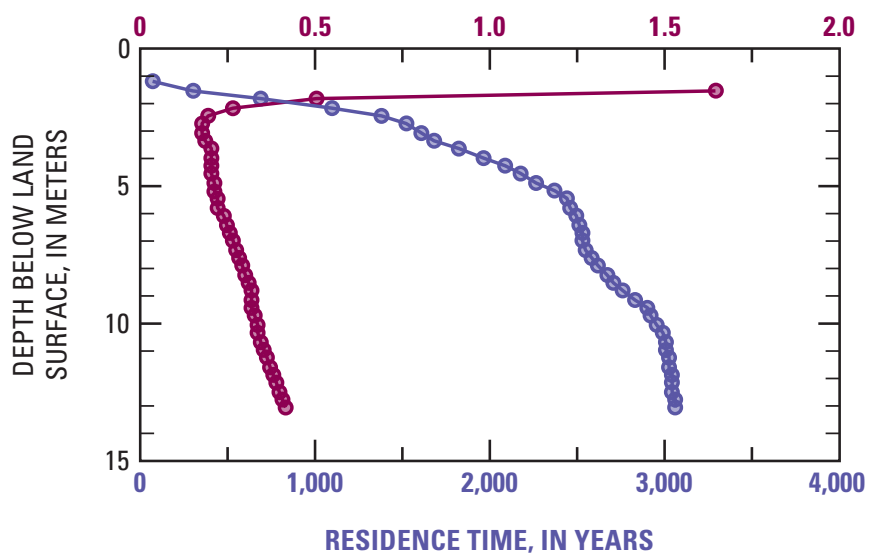

Figure 22. Data for Walnut Gulch borehole WG4, Sierra Vista subwatershed, Arizona. A, Sediment-chloride and pore-water tritium data; $\boldsymbol{B}$, Residence time and infiltration flux, calculated from chloride data. 


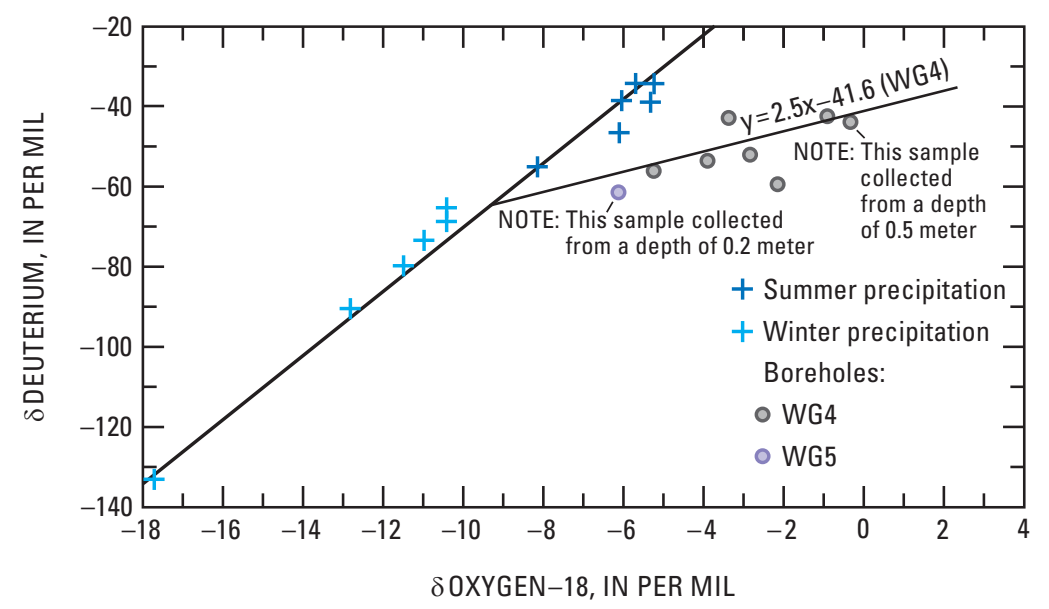

Figure 23. Stable-isotope data for pore water collected from Walnut Gulch basin-floor boreholes WG4 and WG5 and for precipitation, Sierra Vista subwatershed, Arizona.

Physical and hydraulic properties were determined for seven core samples collected from BF1 at depths of 0.3, 4.0, 5.5, 7.0, 8.5, 10.1, and $13.1 \mathrm{~m}$ (table 6). Saturated hydraulic conductivity at 0.3 and $7.0 \mathrm{~m}$ was $2.1 \cdot 10^{-2}$ and $1.4 \cdot 10^{-2} \mathrm{~cm} / \mathrm{s}$, respectively. Porosity was 0.39 and $0.35 \mathrm{~cm}^{3} / \mathrm{cm}^{3}$, and soilwater content was less than $0.02 \mathrm{~cm}^{3} / \mathrm{cm}^{3}$ and $0.11 \mathrm{~cm}^{3} / \mathrm{cm}^{3}$, respectively. The silt and clay content from 0.3 to $7.0 \mathrm{~m}$ was less than 15 percent. The silt and clay content at $8.5 \mathrm{~m}$, however, was 30.7 percent. The saturated hydraulic conductivity of this core was $5.1 \cdot 10^{-3} \mathrm{~cm} / \mathrm{s}$, the porosity was $0.45 \mathrm{~cm}^{3} / \mathrm{cm}^{3}$, and the soil-water content was $0.26 \mathrm{~cm}^{3} / \mathrm{cm}^{3}$. The silt and clay content from 10.1 and $31.1 \mathrm{~m}$ was less than 15 percent.

Sediment-chloride concentrations were less than $5 \mathrm{mg} / \mathrm{kg}$ from the surface to $5.8 \mathrm{~m}$ (fig. 24A) and were between 10 and $32 \mathrm{mg} / \mathrm{kg}$ from 6.1 to $14.3 \mathrm{~m}$. Below $14.3 \mathrm{~m}$, concentrations were less than $10 \mathrm{mg} / \mathrm{kg}$. This chloride profile is not typical for desert soils because the chloride peak is not near the land surface; it is broad, extending almost $8 \mathrm{~m}$; and it has a low concentration.

Tritium activity of the pore water indicates that water has infiltrated to at least $5.3 \mathrm{~m}$, and possibly to $10.2 \mathrm{~m}$, since 1952 (fig. 24A). An infiltration flux could not be calculated using the tritium data because there is not a clear depth of maximum tritium activity. The presence of tritium to $5.3 \mathrm{~m}$, however, corresponds well with the chloride profile, which indicates that about 75 years is required for water to infiltrate to this depth.

Pore-water stable-isotope values show strong evaporative enrichment at $0.5 \mathrm{~m}$ and a slight evaporative enrichment from 3.8 to $13.0 \mathrm{~m}$; values plot along an evaporative trend line that has a slope of 2.0 (fig. 25). The point of intersection between the evaporative trend line and the meteoric water line indicates that historical infiltration at BF1 was similar isotopically to recent winter precipitation.
The chloride, tritium, and stable-isotope data indicate that infiltration occurs at a rate of about $6 \mathrm{~cm} / \mathrm{yr}$ through the more permeable upper zone of sediments to a depth of about $8 \mathrm{~m}$ (fig. 24B). Infiltration is much slower through the less permeable sediments at depths of 8 to $15.8 \mathrm{~m}$. Infiltrated water maintains a low chloride content and high tritium activity through the upper, permeable sediments and transports chloride to the deeper zone as it moves slowly downward through the less permeable sediments. The chloride content in the deep zone is enriched through transport of water to the atmosphere by plant roots.

Borehole WC4c is within the Woodcutters Wash drainage basin. The borehole is about $150 \mathrm{~m}$ south of borehole WC4a on an area of the basin floor that slopes northward toward Woodcutters Wash (fig. 26). Grassland is the primary landcover type at the site (fig. 2). Drilling penetrated terrace deposits of mostly unconsolidated sand and gravel from the surface to $5.8 \mathrm{~m}$; basin fill of clay, silt, sand, and gravel from 5.8 to $7.6 \mathrm{~m}$; and a semiconsolidated conglomerate, the Pantano Formation, from 7.6 to $12.5 \mathrm{~m}$ (fig. $6 P$ ). Electrical conductivity of the terrace and basin fill ranged from less than 10 to $50 \mathrm{mS} / \mathrm{m}$, and the electrical conductivity of the Pantano Formation ranged from 50 to $75 \mathrm{mS} / \mathrm{m}$ (fig. $6 P$ ). A neutron soil-moisture log was not recorded in this borehole.

Physical and hydraulic properties were determined for five core samples from WC4c collected from depths of 1.1, $2.4,3.8,9.9$, and $11.3 \mathrm{~m}$ (table 6). The saturated hydraulic conductivity ranged from $5.1 \cdot 10^{-3}$ to $1.5 \cdot 10^{-2} \mathrm{~cm} / \mathrm{s}$ for the terrace deposits and from $7.2 \cdot 10^{-6}$ to $1.9 \cdot 10^{-5} \mathrm{~cm} / \mathrm{s}$ for the Pantano Formation. Porosity ranged from 0.33 to $0.40 \mathrm{~cm}^{3} / \mathrm{cm}^{3}$ for both units. Soil-water content ranged from 0.07 to $0.15 \mathrm{~cm}^{3} / \mathrm{cm}^{3}$ for the terrace deposits and was 0.24 in the Pantano Formation. 
A. Chloride and tritium

TRITIUM, IN TRITIUM UNITS

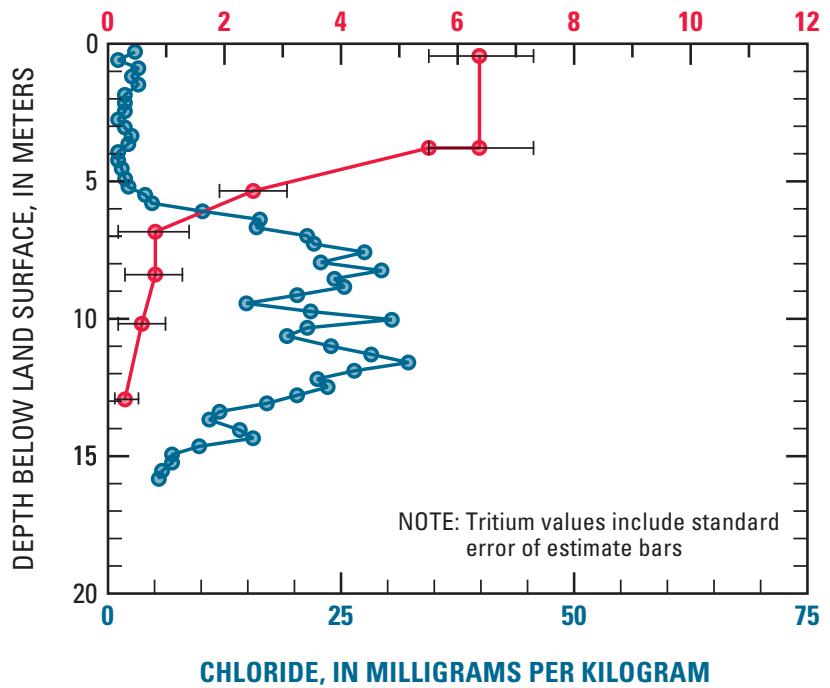

$B$. Residence time and infiltration flux

INFILTRATION FLUX, IN CENTIMETERS PER YEAR

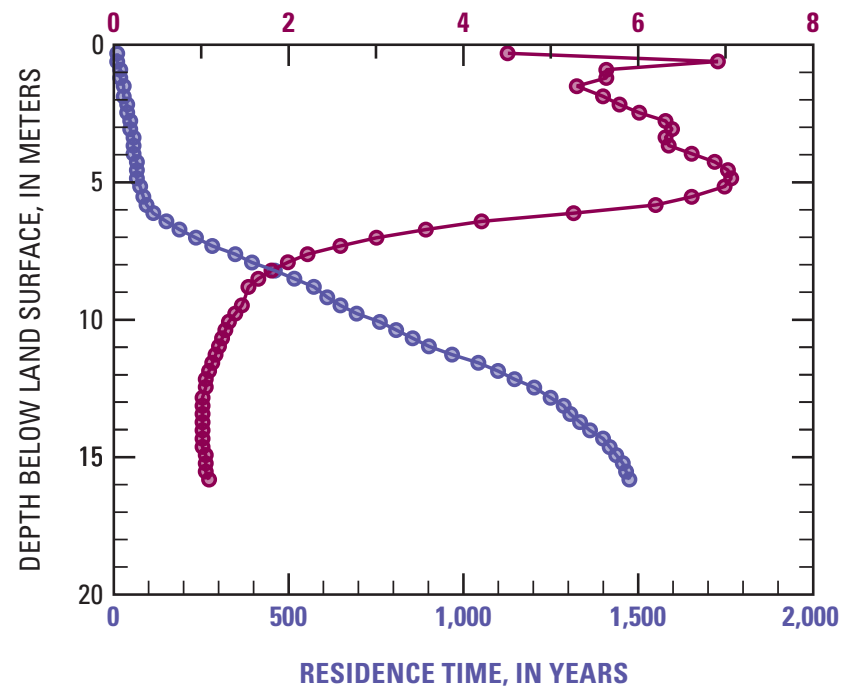

Figure 24. Data for Carr Canyon borehole BF1, Sierra Vista subwatershed, Arizona. A, Sediment-chloride and pore-water tritium data; $\boldsymbol{B}$, Residence time and infiltration flux, calculated from chloride data.

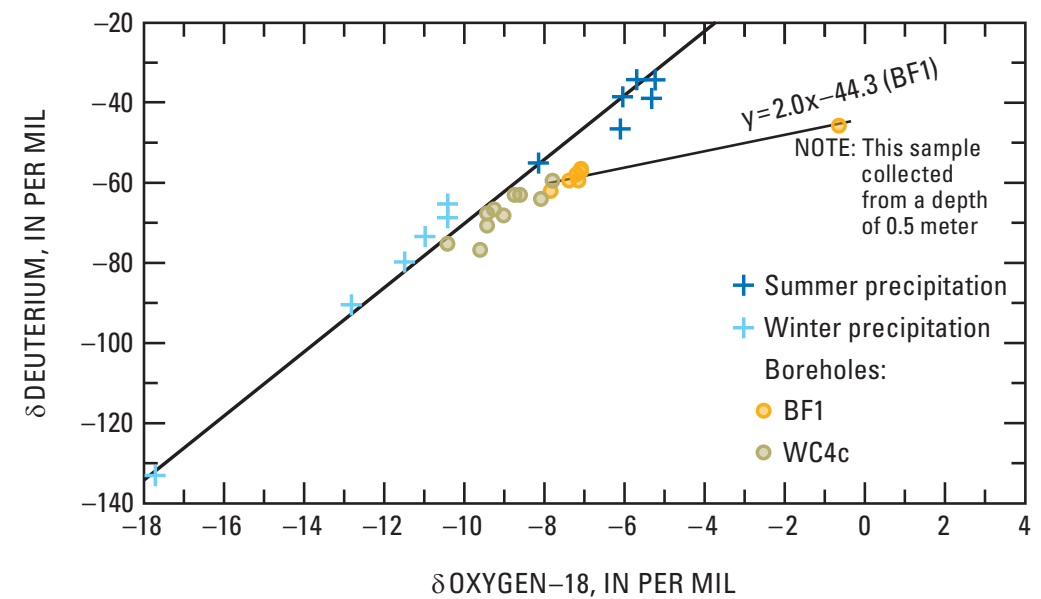

Figure 25. Stable-isotope data for pore water collected from basinfloor boreholes BF1 and WC4c and for precipitation, Sierra Vista subwatershed, Arizona. 


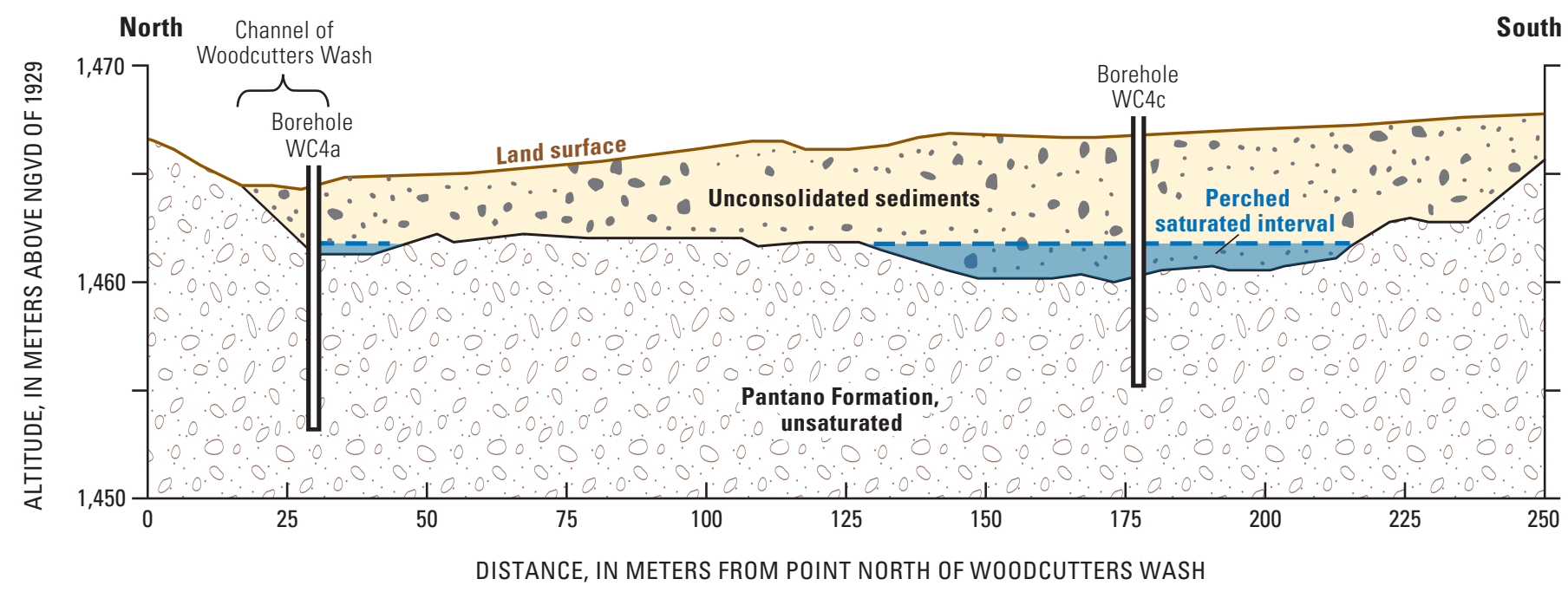

Figure 26. Generalized hydrogeologic section in the area of Woodcutters Wash boreholes WC4a and WC4c, Sierra Vista subwatershed, Arizona.

During drilling in January 2001, the borehole intersected a saturated interval within the terrace deposits and basin fill above the Pantano Formation at $4.7 \mathrm{~m}$ (fig. 27). Sedimentchloride concentrations were $17 \mathrm{mg} / \mathrm{kg}$ at $1.5 \mathrm{~m}$ and generally were less than $6 \mathrm{mg} / \mathrm{kg}$ below $2.7 \mathrm{~m}$ (fig. 28A). Tritium activity of 2.6 to $7.0 \mathrm{TU}$ in pore water to $3.7 \mathrm{~m}$ indicated that recent water is present in the unsaturated zone above the saturated interval (fig. 28A). The chloride data, however, indicate that about 150 years is required for water to infiltrate to the saturated interval, at a flux of about $3 \mathrm{~cm} / \mathrm{yr}$ (fig. 28B). Similar to conditions at site WC4a, the saturated interval at WC4c is probably controlled by infiltration from an upgradient retention basin and subsequent downgradient subflow above the contact of the Pantano Formation with terrace and basin fill.

Pore-water tritium activity indicates that the perched water is infiltrating into the semiconsolidated Pantano Formation very slowly at about $0.4 \mathrm{~cm} / \mathrm{yr}$ (assuming an average soil-water content of $0.07 \mathrm{~cm}^{3} / \mathrm{cm}^{3}$ ). This flux is comparable to the percolation flux for the Pantano Formation at WC4a of $0.3 \mathrm{~cm} / \mathrm{yr}$. Pore-water stable-isotope values above the water table and within the Pantano Formation did not have an evaporative signature, but rather fell within the range

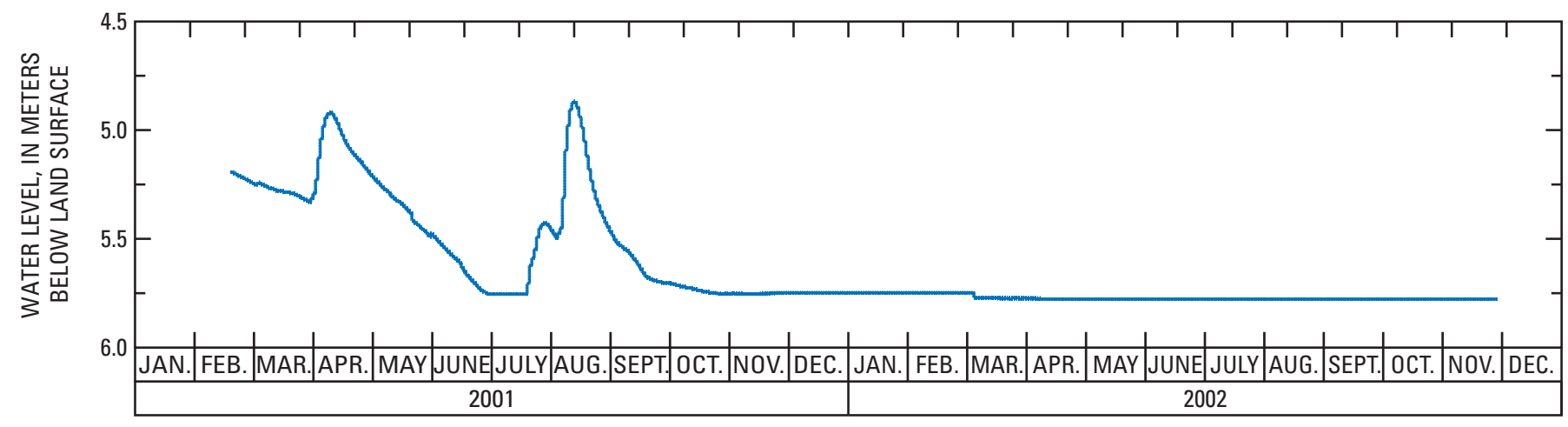

Figure 27. Water level in Woodcutters Wash borehole WC4c, Sierra Vista subwatershed, Arizona. 


\section{A. Chloride and tritium}

TRITIUM, IN TRITIUM UNITS

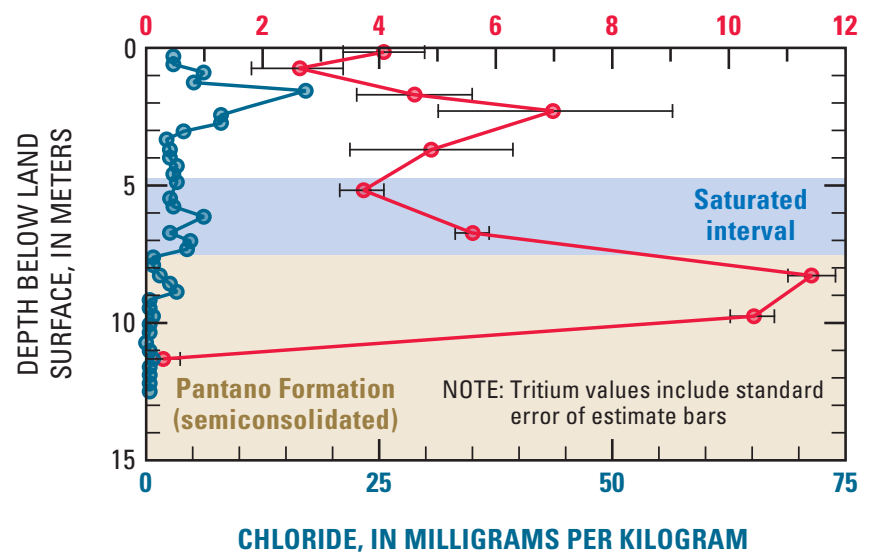

$B$. Residence time and infiltration flux

INFILTRATION FLUX, IN CENTIMETERS PER YEAR

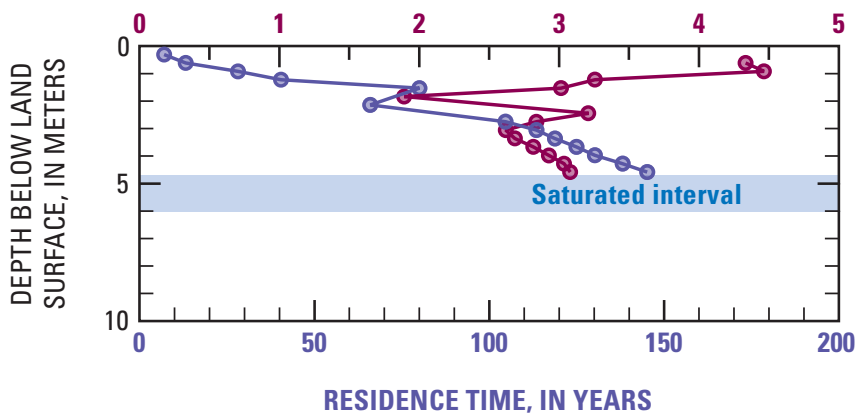

Figure 28. Data for Woodcutters Wash borehole WC4c, Sierra Vista subwatershed, Arizona. A, Sediment-chloride and pore-water tritium data; $\boldsymbol{B}$, Residence time and infiltration flux, calculated from chloride data.

of values for winter precipitation (fig. 25). This indicates that infiltration at WC4c could be dominated by winter precipitation.

\section{Subwatershed Ephemeral-Stream Channel and Basin-Floor Recharge}

Average annual recharge during 2001-2002 was estimated for the Sierra Vista subwatershed by upscaling the infiltration fluxes determined for the basin-floor and ephemeral-stream channel sites. This recharge estimate does not include mountain-front recharge; this study did not monitor streamflow or infiltration near the contact between the hard rock of the mountains and the basin fill. Precipitation during the period of study was slightly below average and primarily occurred from July through September (fig. 4). As a result, the calculated annual recharge represents recharge under drier-than-normal conditions.

At the basin-floor sites in the Walnut Gulch drainage basin, the long-term infiltration fluxes were very low (less than $1 \mathrm{~cm} / \mathrm{yr}$ ). Chloride, tritium, and stable-isotope data indicate long periods of no net deep downward percolation flux beneath the basin floor. Previous investigators have shown that infiltration of precipitation through the basin floor and past the root zone may not be significant in arid areas of the Southwestern United States that have thick unsaturated zones (Phillips, 1994; Walvoord and others, 2002). Additionally, Scott and others (2000) reported that moisture fronts in the unsaturated zone at WG4 and WG5 reach a maximum depth of only $0.5 \mathrm{~m}$ in the summer and only $1.3 \mathrm{~m}$ in the winter.
The chloride, tritium, and stable-isotope data, coupled with the work done by previous investigators, support the conclusion that recharge through the basin floor area is negligible. Infiltration rates could also be negligible in other areas of the basin floor that have soil and vegetation that are similar to those at WG4 and WG5.

Infiltration fluxes were higher at the basin-floor site in the Carr Canyon Wash drainage basin (2 to $6 \mathrm{~cm} / \mathrm{yr}$ ) than at other basin-floor sites. Chloride, tritium, and stable-isotope data indicate active infiltration to $8 \mathrm{~m}$ and a decrease in infiltration below $8 \mathrm{~m}$. The change in the infiltration rate below $8 \mathrm{~m}$ is controlled by an increase in the silt and clay content of the soil. Relatively high infiltration rates could occur in other areas of the basin floor that have soil and vegetation that are similar to those at BF1. The depth that infiltrating water moves through the unsaturated zone, and whether the infiltrating water will ultimately become recharge, however, are strongly dependant on the silt and clay content of limiting soil horizons in the unsaturated zone.

Recharge through ephemeral-stream channels is strongly influenced by the thickness and hydraulic properties of stream alluvium and the permeability of the underlying basin fill. Streamflow infiltration readily occurs through the highly permeable stream alluvium and the unconsolidated basin fill that do not have thick intervals of silt and clay. Infiltration is limited by shallow low-permeability layers, such as bedrock, silt and clay, caliche, or consolidated basin fill. Where the contact between unconsolidated sediments and low-permeability layers is deeper than the depth of root penetration, streamflow infiltrates to depths at which water is probably not removed by evapotranspiration. This water 
will remain in storage within the unsaturated zone until it is vertically displaced by subsequent infiltration and eventually recharges the regional aquifer. Where the contact between unconsolidated sediments and low-permeability layers is shallow, however, aquifer recharge may be minimal because the infiltrated water is available for upward transport by evapotranspiration. Water not lost by evapotranspiration likely flows laterally above the contact until it encounters the limit of the low-permeability layer, reaches permeable fractures, or recharges the aquifer where the water table intersects the top of the low-permeability layer.

Infiltration fluxes at the ephemeral-stream channel sites were very high ( 0.4 to $2.8 \mathrm{~m} / \mathrm{hr}$ ) during streamflow events. Percolation fluxes were also high $(0.1$ to $2.8 \mathrm{~m} / \mathrm{hr})$ immediately following streamflow events. Chloride data indicate that in areas where low-permeability layers are absent in the shallow subsurface, infiltrated water moves past depths where it is available for evapotranspiration, resulting in a net downward water flux. Tritium data indicate that water that has infiltrated since 1952 is reaching depths of more than $20 \mathrm{~m}$. We assume that the net water flux below $20 \mathrm{~m}$ continues to be downward and that infiltrated streamflow ultimately recharges the regional aquifer. Stable-isotope data indicate that both summer and winter streamflows contribute to ephemeralstream channel recharge.

Subwatershed recharge during 2001-2002 from ephemeral-stream channel infiltration was estimated by upscaling the calculated infiltration fluxes to the area covered by each ephemeral-stream channel in the watershed and weighting the fluxes by streamflow duration, evaporation, and transpiration for the 2-year period, per equation 11 (table 12 and fig. 29). Recharge estimates were not derived for channels in the Babocomari River drainage basin (group 1) because the river is perennial over much of its length and, therefore, use of the infiltration parameters derived for the ephemeral-stream channels is not appropriate.

The infiltration flux used in equation 11 was the lowest flux calculated for each channel by sediment-temperature analysis. The calculated infiltration fluxes represent average values of the initial transient infiltration fluxes during each ephemeral-flow event. Consequently, we assume that the lowest calculated infiltration flux best represents the steady-state infiltration flux when determining ephemeralstream channel recharge. This assumption was validated by comparing ephemeral-stream channel recharge rates determined by use of equation 11 with rates determined by using other independent methods (channel-reach water balance, chloride mass balance, ground-water mounding model, and microgravity measurements) for a $6.8-\mathrm{km}$ reach of Walnut Gulch (Goodrich and others, 2004).
Groups 3, 5, 6, and 7 contain ephemeral-stream channels for which infiltration fluxes were determined. We assume that these infiltration fluxes are the same in other ephemeral-stream channels within each group. The infiltration flux determined for Woodcutters Wash was also used for channels in groups 2 and 4, which did not contain instrumented borehole sites. Infiltration fluxes for periods of streamflow were not calculated for Greenbush Draw; therefore, the average percolation flux for periods after cessation of streamflow was used in the Greenbush Draw calculation. Channel segments in Woodcutters Wash and Walnut Gulch underlain at shallow depths by the low-permeability sediments of the lower basin fill were not included in the recharge calculations; it was assumed that similar conditions exist in Coyote Wash, because of its location relative to Woodcutters Wash, Government Draw, and High Knolls Canyon Wash, because of their locations relative to Walnut Gulch (fig. 29).

The streamflow durations measured in Woodcutters Wash during 2001-2002 were greater than those measured in Miller Canyon Wash (table 8 and fig. 7); the longer durations are assumed to be related to the corresponding higher percentage of urban land cover in the drainage basin. The streamflowduration and wetted-channel-width regressions determined for Woodcutters Wash were also used for Coyote and Carr Canyon Washes, whose drainage basins have similar amounts of urban land cover as that in Woodcutters Wash and, likely, have similar runoff characteristics. The streamflow-duration and wetted-channel-width regressions determined for Miller Canyon Wash were used for the remaining channels in groups 2, 3, and 4 .

The estimated annual recharge rate derived from ephemeral-stream channel infiltration during 2001-2002 is $2.95 \mathrm{hm}^{3} / \mathrm{yr}$ (table 12). This rate is slightly lower than average recharge rates of 3.4 to $9.7 \mathrm{hm}^{3} / \mathrm{yr}$ determined by Goodrich and others (2004) for 1999-2000. The rate calculated during this study is lower probably because fewer streamflow events occurred during the 2001-2002 monitoring period than during 1999-2000. At the Tombstone and Huachuca Mountains gages, precipitation during 2001-2002 averaged $36.4 \mathrm{~cm} / \mathrm{yr}$, whereas precipitation during 1999-2000 averaged $47.4 \mathrm{~cm} / \mathrm{yr}$.

The ephemeral-stream channel recharge rate of $2.95 \mathrm{hm}^{3} / \mathrm{yr}$ is about 12 to 19 percent of previous total recharge estimates for the Sierra Vista subwatershed of 15 to 23 hm³/yr (Freethey, 1982; Corell and others, 1996; Goode and Maddock, 2000), indicating that ephemeral-stream channel recharge is a significant component of total recharge. These previous investigators have assumed that recharge occurred only within about $1.5 \mathrm{~km}$ of the mountains; however, the borehole data clearly indicates that when streamflow is available, a significant portion of recharge is distributed along the entire lengths of ephemeral-stream channels (fig. 29). During this study, most of the streamflow, and therefore 
Table 12. Estimated annual ephemeral-stream channel recharge, 2001 and 2002, Sierra Vista subwatershed, Arizona

[Group numbers correspond with groups shown on figure $5 . \mathrm{hm}^{3} / \mathrm{km} / 2 \mathrm{yr}$, cubic hectometers per kilometer per 2-year period; hr/2yr, hours per 2-year period; $\mathrm{m}$, meters; $\mathrm{m} / \mathrm{hr}$, meters per hour; $\mathrm{km}$, kilometer; $\mathrm{hm}^{3} / 2 \mathrm{yr}$, cubic hectometers per 2-year period]

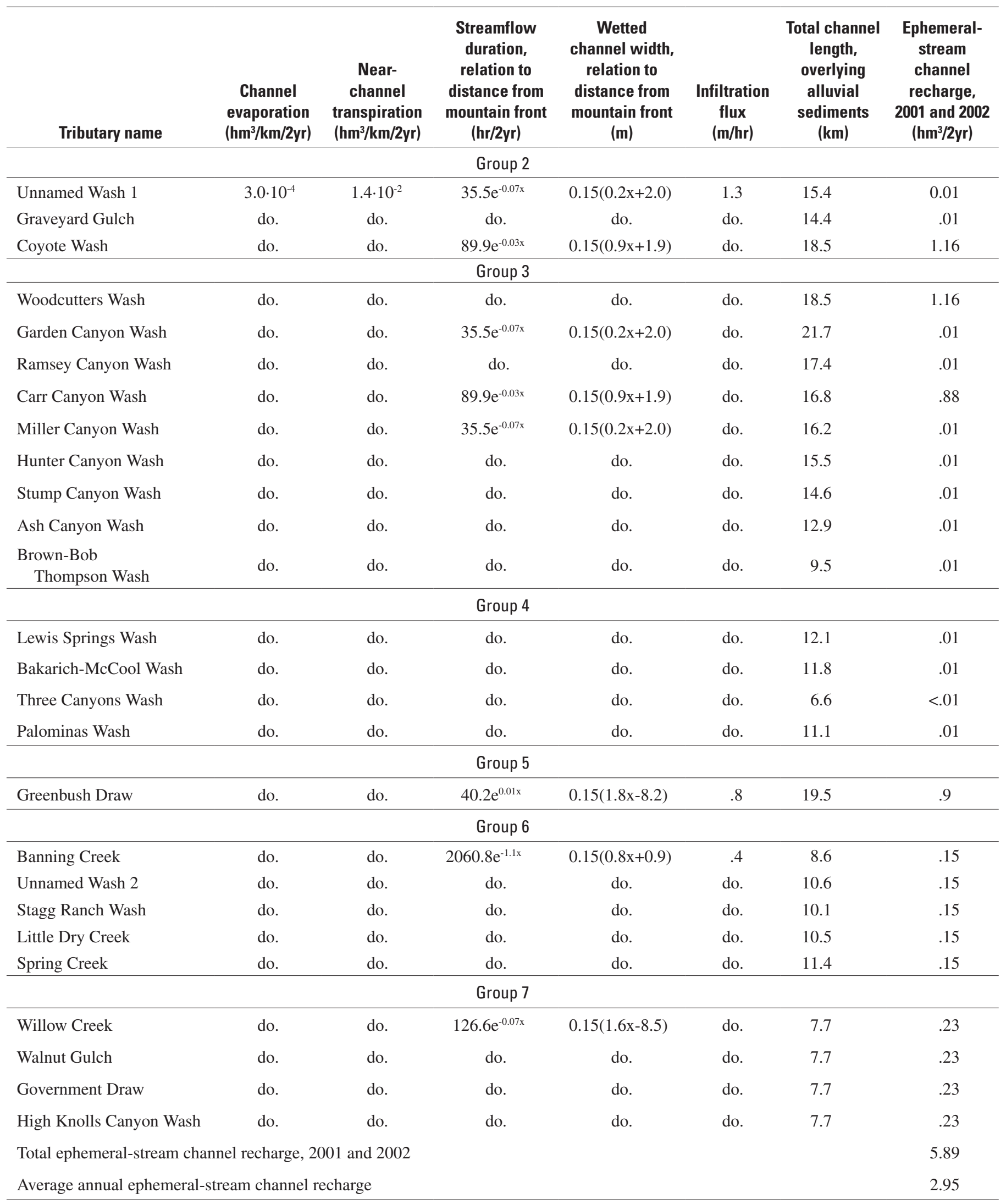




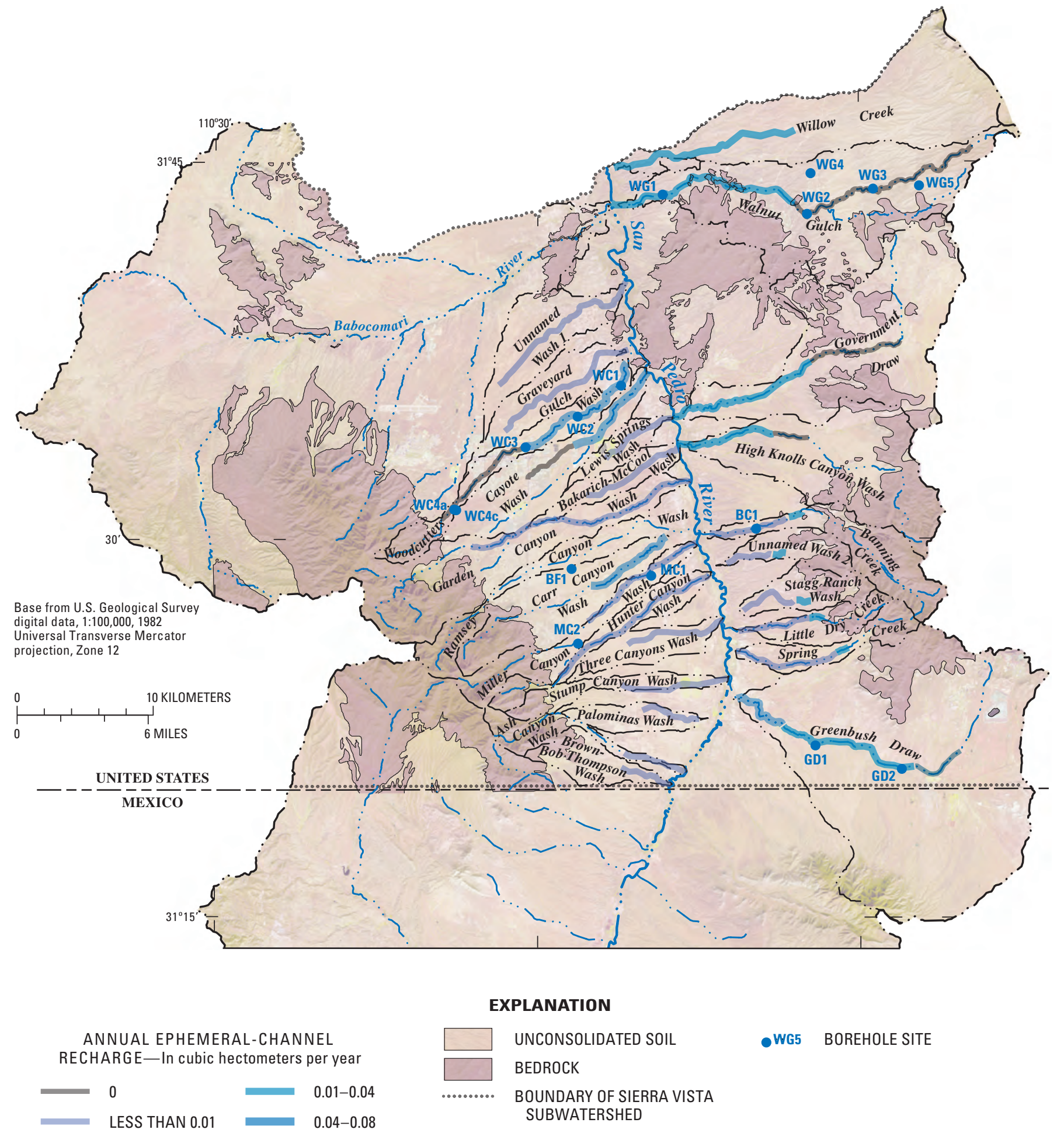

Figure 29. Approximate distribution of annual ephemeral-stream channel recharge, 2001-2002, Sierra Vista subwatershed, Arizona. 
most of the recharge, occurred during the summer; however, stable-isotope data from most of the ephemeral-stream channel boreholes indicate infiltration from past summer and winter streamflow events.

\section{Sensitivity Analysis}

A sensitivity analysis was done to quantify bounds on the calculated ephemeral-stream channel recharge rates by independently varying the recharge calculation parameters in equation 11 within reasonable limits and recalculating recharge along the length of each channel (table 13). Channel evaporation and near-channel transpiration were increased and decreased by 100 percent. Streamflow duration was increased and decreased by 50 percent. The wetted channel width was increased to 100 percent, and decreased to 10 percent, of the total channel width. Calculated infiltration fluxes were increased by 100 percent and decreased by 50 percent.

Recharge rates were most sensitive to the wetted channel width (fig. 30 and table 13)_average annual recharge for the subwatershed increased by 937 percent with the assumption that 100 percent of the channel widths are wetted during streamflow events. Although there is a high degree of uncertainty associated with the wetted channel width value, the assumption that the total channel width is wetted during streamflow is most likely not valid. Recharge was less sensitive to other parameters (fig. 30 and table 13).

Table 13. Sensitivity of estimated annual ephemeral-stream channel recharge to calculation parameters, 2001 and 2002 ,

Sierra Vista subwatershed, Arizona

[Group numbers correspond with groups shown on figure $5 . \mathrm{hm}^{3} / 2 \mathrm{yr}$, cubic hectometers per 2-year period]

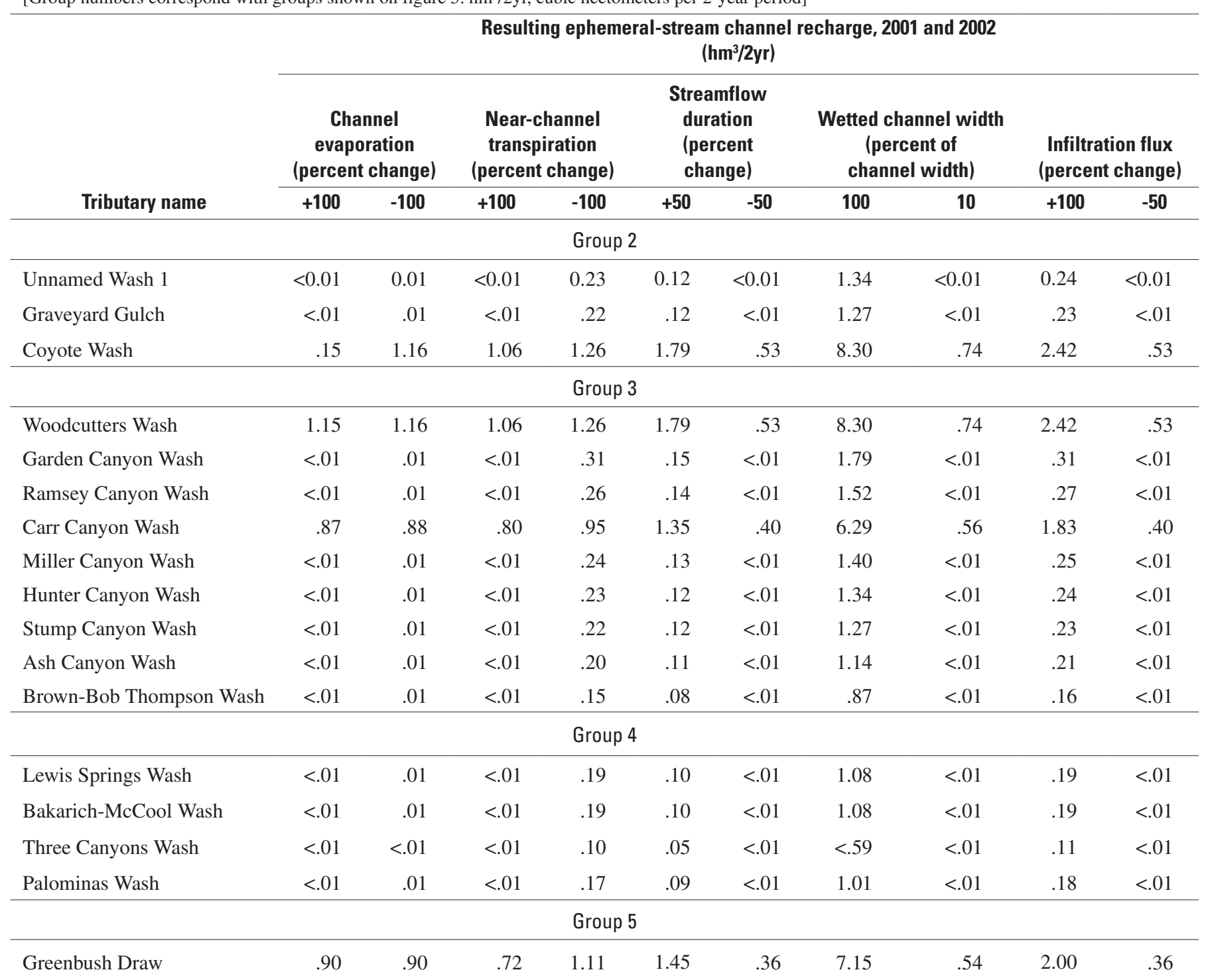


Table 13. Sensitivity of estimated annual ephemeral-stream channel recharge to calculation parameters, 2001 and 2002 , Sierra Vista subwatershed, Arizona-Continued

\begin{tabular}{|c|c|c|c|c|c|c|c|c|c|c|}
\hline \multirow[b]{3}{*}{ Tributary name } & \multicolumn{10}{|c|}{ Resulting ephemeral-stream channel recharge, 2001 and 2002 (hm³/2yr) } \\
\hline & \multicolumn{2}{|c|}{$\begin{array}{c}\text { Channel } \\
\text { evaporation } \\
\text { (percent change) }\end{array}$} & \multicolumn{2}{|c|}{$\begin{array}{c}\text { Near-channel } \\
\text { transpiration } \\
\text { (percent change) }\end{array}$} & \multicolumn{2}{|c|}{$\begin{array}{l}\text { Streamflow } \\
\text { duration } \\
\text { (percent } \\
\text { change) }\end{array}$} & \multicolumn{2}{|c|}{$\begin{array}{l}\text { Wetted channel width } \\
\text { (percent of channel } \\
\text { width) }\end{array}$} & \multicolumn{2}{|c|}{$\begin{array}{l}\text { Infiltration flux } \\
\text { (percent change) }\end{array}$} \\
\hline & +100 & -100 & +100 & -100 & +50 & -50 & 100 & 10 & +100 & -50 \\
\hline \multicolumn{11}{|c|}{ Group 6} \\
\hline Unnamed Wash 2 & .15 & .15 & .10 & .21 & .25 & .05 & 1.32 & .08 & .35 & .05 \\
\hline Stagg Ranch Wash & .15 & .15 & .10 & .21 & .25 & .05 & 1.32 & .08 & .35 & .05 \\
\hline Little Dry Creek & .15 & .15 & .10 & .21 & .25 & .05 & 1.32 & .08 & .35 & .05 \\
\hline Spring Creek & .15 & .15 & .10 & .21 & .25 & .05 & 1.32 & .08 & .35 & .05 \\
\hline Walnut Gulch & .23 & .24 & .12 & .35 & .41 & .06 & 2.21 & .12 & .58 & .06 \\
\hline Government Draw & .23 & .24 & .12 & .35 & .41 & .06 & 2.21 & .12 & .58 & .06 \\
\hline High Knolls Canyon Wash & .23 & .24 & .12 & .35 & .41 & .06 & 2.21 & .12 & .58 & .06 \\
\hline $\begin{array}{l}\text { Total ephemeral-stream } \\
\text { channel recharge, } \\
\text { 2001-2002 }\end{array}$ & 5.74 & 5.93 & 4.62 & 9.74 & 10.70 & 2.31 & 61.18 & 3.46 & 15.55 & 2.31 \\
\hline $\begin{array}{l}\text { Average annual ephemeral- } \\
\text { stream channel recharge }\end{array}$ & 2.87 & 2.97 & 2.31 & 4.87 & 5.35 & 1.16 & 30.59 & 1.73 & 7.78 & 1.16 \\
\hline $\begin{array}{l}\text { Percent difference to previ- } \\
\text { ously determined average } \\
\text { annual ephemeral-stream } \\
\text { channel recharge }\end{array}$ & -2.7 & .7 & -21.7 & 65.1 & 81.4 & -60.7 & 937 & -41.4 & 164 & -60.7 \\
\hline
\end{tabular}



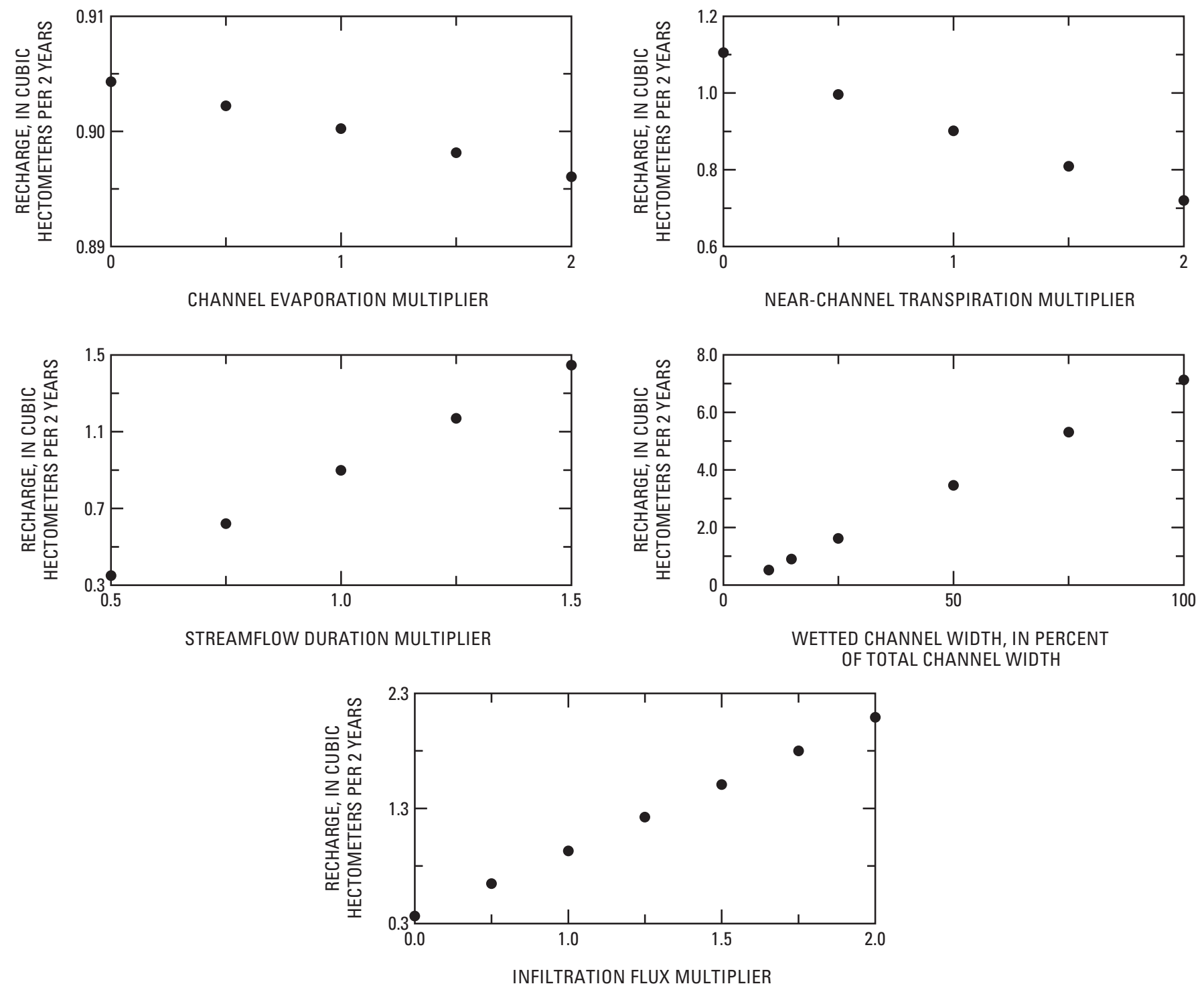

Figure 30. Examples of sensitivity analysis results, Greenbush Draw, Sierra Vista subwatershed, Arizona, 2001-2002. 
The highest and lowest annual recharge rates determined through the sensitivity analysis (excluding the rate determined for 100 percent wetted channel width) produce bounds of $+7.78 \mathrm{hm}^{3} / \mathrm{yr}$ and $-1.16 \mathrm{hm}^{3} / \mathrm{yr}$ on annual ephemeral-stream channel recharge for 2001-2002.

\section{Summary and Conclusions}

As part of a larger project to better understand the hydrologic system in the Sierra Vista subwatershed, infiltration and recharge fluxes through the subwatershed's ephemeralstream channels and basin floor were investigated. Data used in this study include information resulting from the drilling and coring of 16 boreholes: 12 within ephemeral-stream channels and 4 on the basin floor. The collected data includes physical, hydraulic, and thermal properties of sediment; chloride concentrations of sediment; pore-water stableisotope values and tritium activity; neutron soil-moisture and EMI logs; continuous sediment-temperature profiles; and continuous water levels.

Infiltration fluxes through the basin floor were 0.2 to $6 \mathrm{~cm} / \mathrm{yr}$. At the basin-floor sites in the Walnut Gulch drainage basin, long-term infiltration fluxes were very low (less than $1 \mathrm{~cm} / \mathrm{yr}$ ). Chloride, tritium, and stable-isotope data indicate long periods of no net deep downward percolation flux beneath the basin floor. The sediment-chloride profiles coupled with previous studies in the arid Southwestern United States indicate that water infiltrated through the basin floor does not move downward past the root zone for long periods of time. Infiltration rates could also be negligible in other areas of the basin floor that have soil and vegetation similar to those at WG4 and WG5.

Infiltration fluxes in the Carr Canyon drainage basin (2 to $6 \mathrm{~cm} / \mathrm{yr}$ ) were higher than at other basin-floor sites. Chloride, tritium, and stable-isotope data indicate active infiltration to $8 \mathrm{~m}$, and a decrease in infiltration below $8 \mathrm{~m}$. The change in the infiltration rate below $8 \mathrm{~m}$ is controlled by an increase in the silt and clay content of the sediment. At this site, the depth that infiltrating water moves through the unsaturated zone and whether the infiltrating water will ultimately become recharge are strongly dependant on the silt and clay content of limiting soil horizons in the unsaturated zone. Relatively high infiltration rates could occur in other areas of the basinfloor that have soil and vegetation similar to those at BF1, but detailed subsurface soil data are necessary to determine if infiltrated water will become recharge.

Infiltration through ephemeral-stream channels in the Sierra Vista subwatershed is rapid, occurs to depths of at least $20 \mathrm{~m}$, and occurs from the edge of the mountain front to as far as $25.6 \mathrm{~km}$ downstream. During streamflow events, infiltration fluxes ranged from 0.4 to $2.8 \mathrm{~m} / \mathrm{hr}$. After streamflow ended, percolation fluxes ranged from 0.1 to $2.8 \mathrm{~m} / \mathrm{hr}$. In areas where low-permeability layers are absent in the shallow subsurface, infiltrated water moves past depths where it is available for evapotranspiration, resulting in a net downward flux. This deep downward water flux is assumed to ultimately recharge the regional aquifer.

Recharge from ephemeral-stream channel infiltration is highly dependant on the thickness and hydraulic properties of the stream alluvium, the permeability of the sediments underlying the stream alluvium, the streambed geomorphology, the runoff characteristics of the contributing drainage basin, and the availability of streamflow. Ephemeralstream channel recharge for the entire Sierra Vista subwatershed was estimated by upscaling the calculated infiltration fluxes to the area covered by each ephemeralstream channel and weighting the fluxes by streamflow duration, evaporation, and transpiration. The resulting average annual recharge during 2001-2002 is $2.95 \mathrm{hm}^{3} / \mathrm{yr}$. Analysis indicates that the calculated recharge rates are most sensitive to wetted channel width and are less sensitive to the other parameters of evaporation, transpiration, streamflow duration, and infiltration flux. The upper and lower bounds for the annual recharge estimate determined from the sensitivity analysis are $+7.78 \mathrm{hm}^{3} / \mathrm{yr}$ and $-1.16 \mathrm{hm}^{3} / \mathrm{yr}$, respectively.

The calculated annual ephemeral-stream channel recharge rate indicates that ephemeral-stream channel infiltration is a significant contributor to total recharge in the subwatershed. When streamflow is available, recharge is significant along the entire length of the ephemeral-stream channels. In addition, ephemeral-stream channel recharge occurs during both summer and winter streamflow events.

\section{References Cited}

Allison, G.B., and Hughes, M.W., 1978, The use of environmental chloride and tritium to estimate total recharge to an unconfined aquifer: Australian Journal of Soil Resources, v. 16, p. 181-195.

Allison, G.B., Stone, W.J., and Hughes, M.W., 1985, Recharge in karst and dune elements of a semi-arid landscape as indicated by natural isotopes and chloride: Journal of Hydrology, v. 76, p. 1-26.

Anderson, T.W., Freethey, G.W., and Tucci, P., 1992, Geohydrology and water resources of alluvial basins in south-central Arizona and parts of adjacent states: U.S. Geological Survey Professional Paper 1406-B, 67 p.

Arizona Department of Economic Security, 1997, July 1, 1997, to July 1, 2050, Arizona subcounty population projections: Population Statistics Unit, Research Administration, accessed February 21, 2003 at http://www.de.state.az.us/ links/economic/webpage/popweb/subco97.html 
Blasch, K.W., Fleming, J.B., Ferré, P.A., and Hoffmann, J.P., 2000, One- and two-dimensional temperature and moisturecontent profiling of an ephemeral stream channel in a semiarid watershed: EOS, Trans. Amer. Geophys. Union, v. 81 , no. 48 , p. F502.

Brown, S.G., Davidson, E.S., Kister, L.R., and Thomsen, B.W., 1966, Water resources of Fort Huachuca Military Reservation, southeastern Arizona: U.S. Geological Survey Water-Supply Paper 1819-D, p. D1-D57.

Campbell, G.S., Calissendorff, C., and Williams, J.H., 1991, Probe for measuring soil-specific heat using a heat-pulse method: Soil Science Society of America Journal, v. 55, no. 1, p. 291-293.

Cayan, D.R., and Webb, R.H., 1992, El Niño/southern oscillation and streamflow in the Western United States, in Diaz, H.F., and Markgraf, V., eds., El Niño historical and paleoclimatic aspects of the southern oscillation: Cambridge, United Kingdom, Cambridge University Press, p. 29-68.

Cayan, D.R., Redmond, K.T., and Riddle, L.G., 1999, ENSO and hydrologic extremes in the Western United States: Journal of Climate, v. 12, no. 9, p. 2881-2893.

Constantz, J., Tyler, S.W., and Kwicklis, E., 2003, Temperature-profile methods for estimating percolation rates in arid environments: Vadose Zone Journal, v. 2, p. $12-24$.

Constantz, J., Stonestrom, D., Stewart, A.E., Niswonger, R., and Smith, T.R., 2001, Analysis of streambed temperatures in ephemeral channels to determine streamflow frequency and duration: Water Resources Research, v. 37, no. 2, p. 317-328.

Constantz, J., and Thomas, C.L., 1996, The use of streambed temperature profiles to estimate the depth, duration, and rate of percolation beneath arroyos: Water Resources Research, v. 32 , no. 12 , p. 3597-3602.

Corell, S.W., Corkhill, F., Lovvik, D., and Putman, F., 1996, A groundwater flow model of the Sierra Vista subwatershed of the upper San Pedro Basin, southeastern Arizona: Phoenix, Arizona Department of Water Resources Modeling Report No. 10, 107 p.

Craig, H., 1961, Isotopic variations in meteoric waters: Science, v. 133, p. 1702-1703.

Danielson, R.E., and Sutherland, P.L., 1986, Porosity, chap. 18 in Klute, A., ed., Methods of soil analysis, Part I, Physical and mineralogical methods ( $2 \mathrm{~d}$ ed.): Madison, Wisconsin, American Society of Agronomy and Soil Science Society of America, p. 443-461.

Decagon Devices, Inc., 1999, ThermoLink system manual: Pullman, Washington, v. 2.5, v.p.
Driscoll, F.G., 1986, Groundwater and wells, 2d ed.: St. Paul, Minnesota, Johnson Division, 1108 p.

Freethey, G.W., 1982, Hydrologic analysis of the upper San Pedro Basin from the Mexico-United States international boundary to Fairbank, Arizona: U.S. Geological Survey Open-File Report 82-752, 52 p.

Gallaher, B.M., 1979, Recharge properties of the Tucson Basin aquifer as reflected by the distribution of a stable isotope: Tucson, University of Arizona, unpublished master's thesis, $92 \mathrm{p}$.

Gardner, W.R., 1956, Calculation of capillary conductivity from pressure plate outflow data: Soil Science Society Proceedings, v. 20, p. 317-320.

Gee, G.W., and Bauder, J.W., 1986, Particle-size analysis, chap. 15 in Klute, A., ed., Methods of soil analysis, Part I, Physical and mineralogical methods (2d ed.): Madison, Wisconsin, American Society of Agronomy and Soil Science Society of America, p. 383-411.

Gettings, M.E., and Houser, B.B., 1995, Preliminary results of modeling the gravity anomaly field in the upper San Pedro Basin, southeastern Arizona: U.S. Geological Survey Open-File Report 95-76, 9 p.

Goode, T.C., and Maddock, T., 2000, Simulation of groundwater conditions in the Upper San Pedro Basin for the evaluation of alternative futures: Tucson, University of Arizona, Hydrology and Water Resources Report no. $00-030,113 \mathrm{p}$.

Goodrich, D.C., Williams, D.G., Unkrich, C.L., Hogan, J.F., Scott, R.L., Hultine, K.R., Pool, D.R., Coes, A.L., and Miller, S., 2004, Comparison of methods to estimate ephemeral channel recharge, Walnut Gulch, San Pedro River Basin, Arizona, in Hogan, J.F., Phillips, F.M., and Scanlon, B.R., eds., Groundwater recharge in a desert environment-The Southwestern United States: American Geophysical Union, Water Science and Applications Series, vol. 9, 302 p.

Gungle, Bruce, 2003, Estimation of ephemeral streamflow duration using temperature methods in the Upper San Pedro River Basin, Arizona, in Proceedings of first interagency conference on research in watersheds, October 27-30, 2003: Benson, Arizona, p. 146-151.

Halverson, P.H., 1984, An exploratory gravity survey in the upper San Pedro Valley, southeastern Arizona: Tucson, University of Arizona, master's thesis, 85 p. 
Hammermeister, D.P., Blout, D.O., and McDaniel, J.C., 1986, Drilling and coring methods that minimize the disturbance of cuttings, core, and rock formations in the unsaturated zone, Yucca Mountain, Nevada, in Klute, A.L., ed., Proceedings of the National Water Well Association Conference on Characterization and Monitoring of the Vadose (Unsaturated) Zone: Worthington, Ohio, National Water Well Association, p. 507-541.

Haynes, C.V., 1968, Preliminary report on the Late Quaternary geology of the San Pedro Valley, Arizona: Arizona Geological Society Guidebook III, p. 76-96.

Healy, R.W. and Ronan, A.D., 1996, Documentation of computer program VS2DH for simulation of energy transport in variably saturated porous media-Modification of the U.S. Geological Survey's computer program VS2DT: U.S. Geological Survey Water-Resources Investigations Report 96-4230, 36 p.

Hsieh, P.A., Wingle, W., and Healy, R.W., 2000, VS2DI-A graphical software package for simulating fluid flow and solute or energy transport in variably saturated porous media: U.S. Geological Survey Water-Resources Investigations Report 99-4130, 16 p.

Izbicki, J.A., Radyk, J., and Michel, R.L., 2000, Water movement through a thick unsaturated zone underlying an intermittent stream in the western Mojave Desert, southern California: Journal of Hydrology, v. 238, p. 194-219.

Keith, S.J., 1981, Stream channel recharge in the Tucson Basin and its implications for groundwater management: Tucson, University of Arizona, unpublished master's thesis, 84 p.

Kipp, K.L., 1987, HST3D: A computer code for simulation of heat and solute transport in three-dimensional groundwater systems: U.S. Geological Survey Water-Resources Investigations Report 86-4095, 517 p.

Klute, A., and Dirksen, C., 1986, Hydraulic conductivity and diffusivity: Laboratory Methods, chap. 28, in Klute, A., ed., Methods of soil analysis, Part I, Physical and mineralogical methods ( $2 \mathrm{~d}$ ed.): Madison, Wisconsin, American Society of Agronomy and Soil Science Society of America, p. 687-734.

McCabe, G.J., and Dettinger, M.D., 1999, Decadal variations in the strength of ENSO teleconnections with precipitation in the Western United States: International Journal of Climatology, v. 19, no. 13, p.1399-1410.

Miller, S.N., Semmens, D.J., Miller, R.C., Hernandez, M., Miller, P., Goodrich, D.C., Kepner, W.G., and Ebert, D., 2002, Automated Geospatial Watershed Assessment (AGWA) - A GIS-based hydrologic modeling toolDocumentation and user manual: U.S. Department of Agriculture, Agricultural Research Service, ARS-1446, $69 \mathrm{p}$.
Peterson, B., 1999, 9510 slim hole induction tool test results and field application to groundwater monitoring wells: Century Geophysical Corp., User Guide, no. 317, 4 p.

Phillips, F.M., and Stone, W.J., 1985, Chemical considerations in groundwater recharge, Socorro, New Mexico: Symposium on Water and Science, New Mexico Water Resources Research Institute, Las Cruces, New Mexico, p. 109-125.

Phillips, F.M., Mattick, J.L., and Duval, T.A., 1988, Chlorine-36 and tritium from nuclear weapons fallout as tracers for long-term liquid movement in desert soils: Water Resources Research, v. 24, p. 1877-1891.

Phillips, F.M., 1994, Environmental tracers for water movement in desert soils of the American Southwest: Soil Science of America Journal, v. 58, p. 15-24.

Pool, D.R., and Coes, A.L., 1999, Hydrogeologic investigations of the Sierra Vista subwatershed of the Upper San Pedro Basin, Cochise County, Southeast Arizona: U.S. Geological Survey Water-Resources Investigations Report 99-4197, 41 p.

Redmond, K.T., and Koch, R.W., 1991, Surface climate and streamflow variability in the Western United States and their relationship to large-scale circulation indices: Water Resources Research, v. 27, no. 9, p. 2381-2399.

Richards, L.A., 1931, Capillary conduction of liquids through porous mediums: Physics, v. 1, p. 318-333.

Scanlon, B.R., 1991, Evaluation of moisture flux from chloride data in desert soils: Journal of Hydrology, v. 128, p. 137-156.

Scott, R.L., Shuttleworth, W.J., Keefer, T.O., and Warrick, A.W., 2000, Modeling multiyear observations of soil moisture recharge in the semiarid American Southwest: Water Resources Research, v. 36, no. 8, p. 2233-2247.

Sharma, M.L., and Hughes, M.W., 1985, Groundwater recharge estimation using chloride, deuterium and oxygen18 profiles in the deep coastal sands of western Australia: Journal of Hydrology, v. 81, p. 93-109.

Taniguchi, M., and Sharma, M.L., 1990, Solute and heat transport experiments for estimating recharge rate: Journal of Hydrology, v. 119, p. 57-96.

Thermo Electron Corporation, 2000, Orion chloride electrode instruction manual: Burlington, Ontario, Canada, Thermo Electron Corporation, 39 p.

U.S. Census Bureau, 2000, Census 2000 Summary File 1, accessed February 21, 2003, at http://www.factfinder. census.gov/servlet/GCTTable?ds_name=DEC_2000_ SF1_U\&geo_id=04000US04\&_box_head_nbr=GCTPH1\&format $=$ ST-7 
U.S. Environmental Protection Agency, 2003, Upper San Pedro watershed geodata, accessed June 1, 2003, at http://:www.epa.gov/esd/land-sci/html2/HTML/PAGES/ sanpedro_uspws.htm

van Genuchten, M.T., 1980, A closed-form equation for predicting the hydraulic conductivity of unsaturated soil: Soil Science Society of America Journal, v. 44, p. 892-898.

van Genuchten, M.T., Leij, F.J., and Yates, S.R., 1991, The RETC code for quantifying the hydraulic functions of unsaturated soils: U.S. Salinity Laboratory, 85 p.

Walvoord, M.A., Phillips, F.M., Tyler, S.W., and Hartsough, P.C., 2002, Deep arid system hydrodynamics-2, Application to paleohydrologic reconstruction using vadose zone profiles from the northern Mojave Desert: Water Resources Research, v. 38, no. 12, p.

Webb, R.H., and Betancourt, J.L., 1992, Climatic variability and flood frequency of the Santa Cruz River, Pima County, Arizona: U.S. Geological Survey Water-Supply Paper 2379, $40 \mathrm{p}$.

Western Regional Climate Center, 2003, Arizona climate summaries, accessed June 1, 2003, at http://www.wrcc.dri. edu/summary/climsmaz.html 
This page left blank intentionally. 
This page left blank intentionally. 


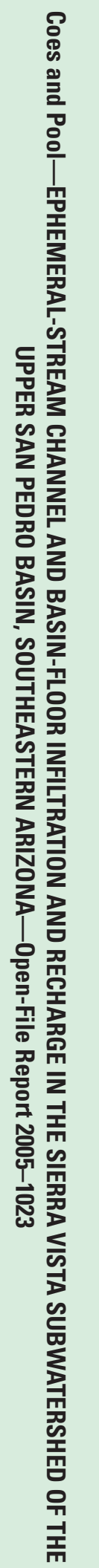

8 Printed on recycled paper 